$S$

Page 1 of $2 \quad \begin{aligned} & \text { Proj } \\ & \text { ECN }\end{aligned}$

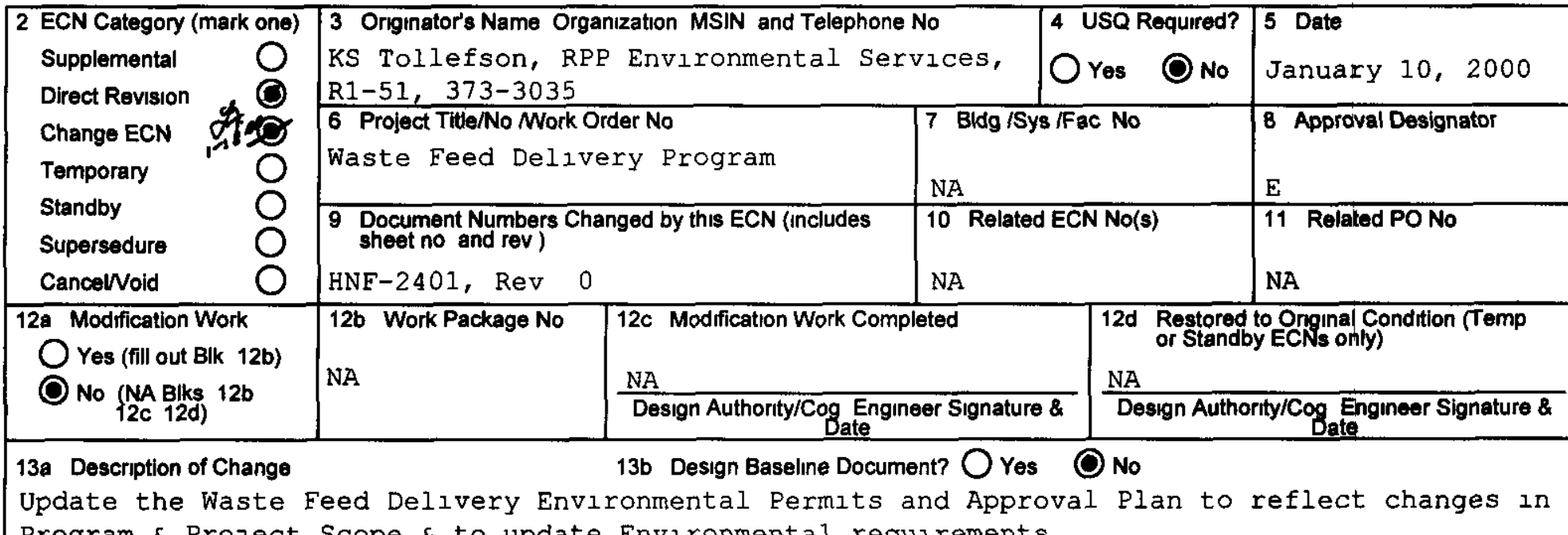

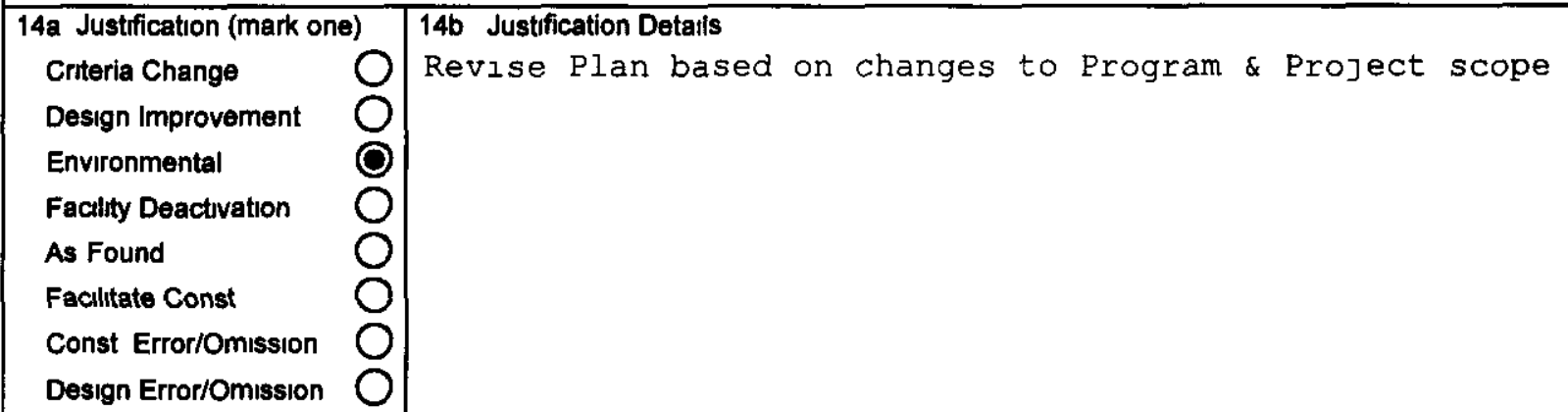

15 Distribution (Include name MSIN and no of copies)

See attached Distribution Sheet 


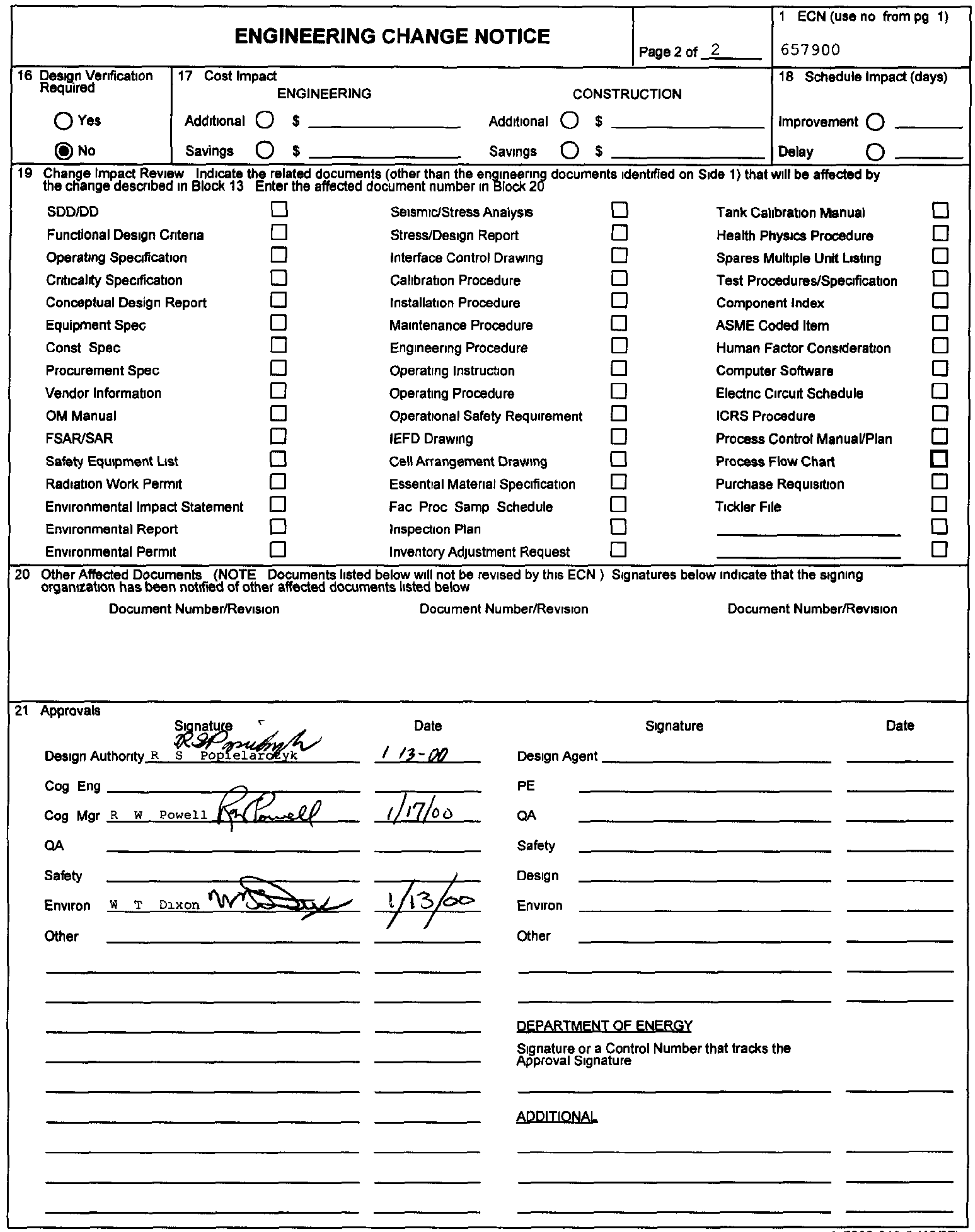




\title{
Waste Feed Delivery Environmental Permits and Approvals Plan
}

\author{
$K$ S Tollefson and $R \quad D$ Potter (MACTEC) \\ CH2M HILL Hanford Group, Inc \\ Richland WA 99352 \\ U S Department of Energy Contract DE AC06 99RL14047

$\begin{array}{ll}\text { EDT/ECN } 657900 & \text { UC } 721 \\ \text { Cost Center } & \text { Charge Code } 110373 \\ \text { B\&R Code } & \text { Total Pages } 106\end{array}$

Key Words

Environmental permits waste feed delivery

\begin{abstract}
This plan describes the environmental permits approvals, and other requirements that may affect establishment of a waste feed delivery system for the Hanford Site's River Protection Project This plan identifies and screens environmental standards for potential applicability, outlines atlternatives for satisfying applicable standards, and describes preferred permitting and approval approaches
\end{abstract}

TRADEMARK DISCLAIMER Reference herein to any specific commercial product process or service by trade name trademark manufacturer or ofherwise does not necessarily constitute or imply its endorsement recommendation or favoring by the United States Government or any agency thereof or its contractors or subcontractors

Printed in the United States of America To obtain copies of this document contact Document Control Services P O Box 950 Mailstop H6 08 Richland WA 99352 Phone (509) 3722420 Fax (509) 376-4989
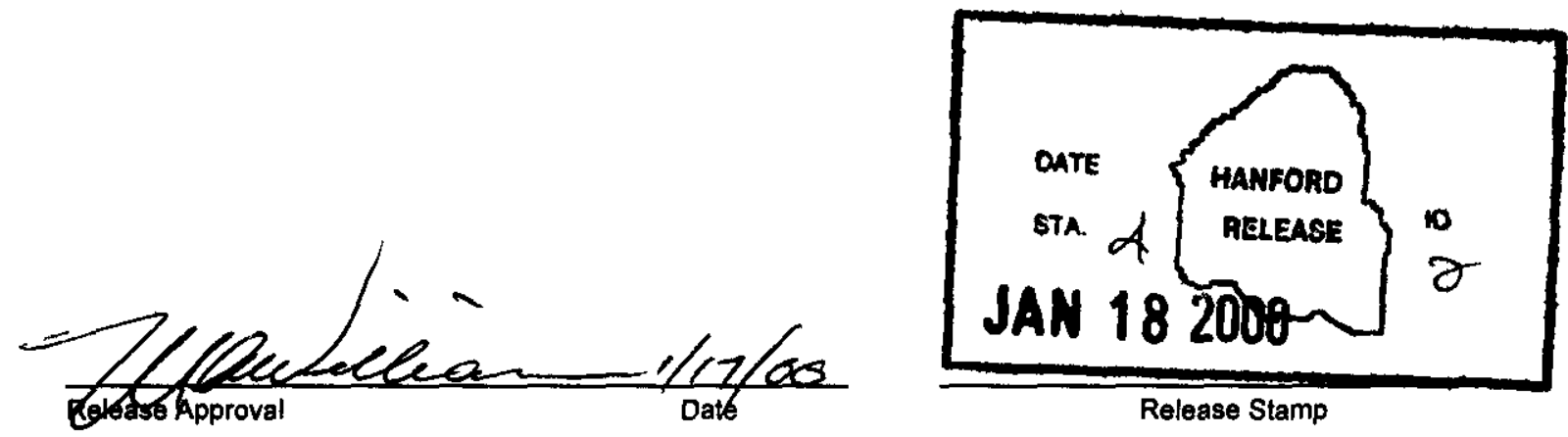

Approved For Publıc Release 
RECORD OF REVISION

(2) Title

Waste Feed Delıvery Environmental Permits and Approvals Plan

Change Control Record
(3) Revision

(7)

0

Inltial Release, EDT-608764, 07/06/98
(1) Document Number

HNF-2401
Page 1

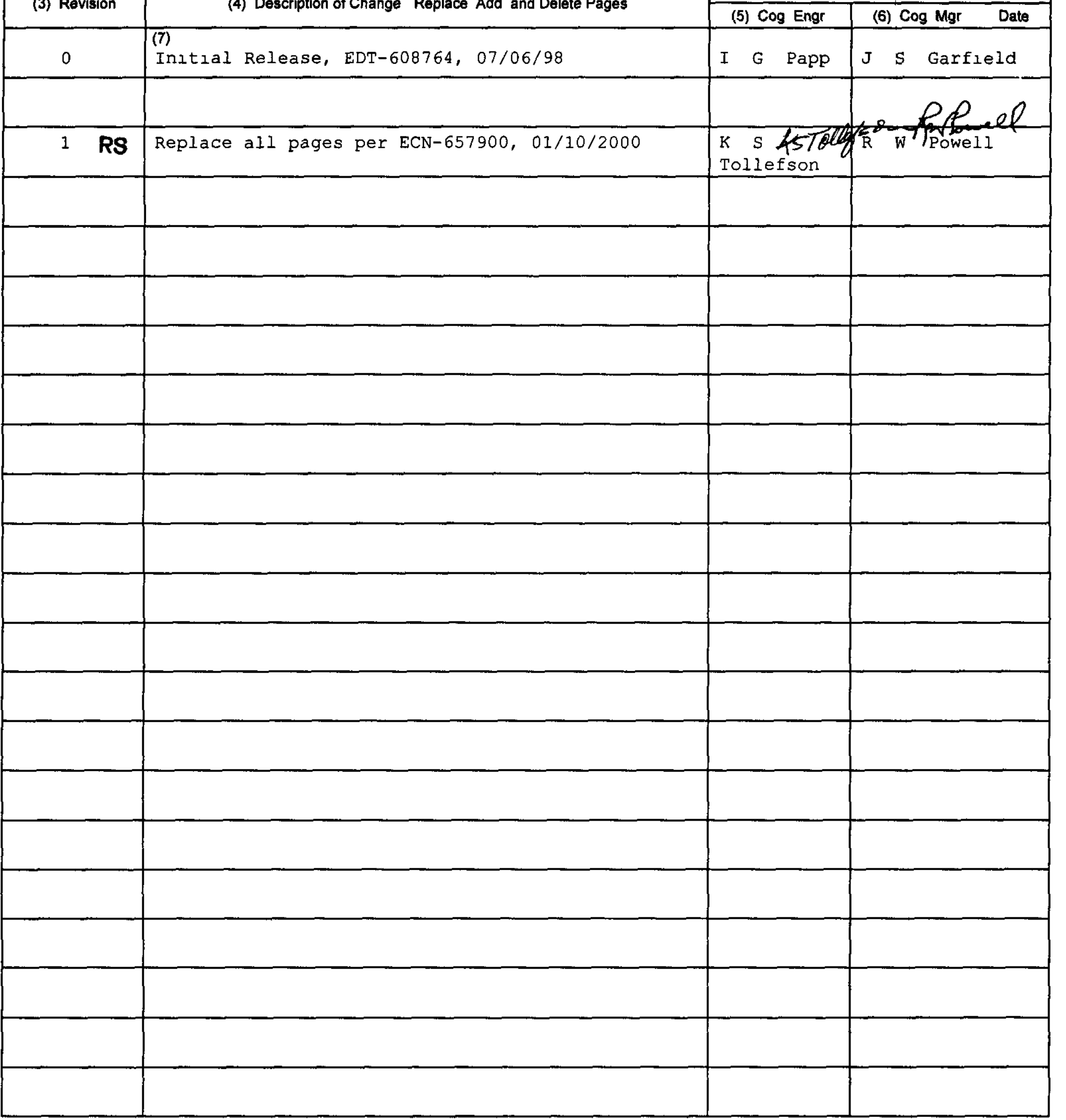




\title{
WASTE FEED DELIVERY ENVIRONMENTAL PERMITS AND APPROVALS PLAN
}

\author{
January 2000 \\ K S Tollefson \\ CH2M HILL Hanford Group, Inc \\ Richland, Washington \\ R D Potter \\ MACTEC Inc \\ Richland, Washington
}

Prepared for

U S Department of Energy Office of River Protection

Richland, Washington 
HNF-2401

Revision 1

This page intentionally left blank 
HNF-2401

Revision 1

\section{EXECUTIVE SUMMARY}

The US Department of Energy Office of River Protection is responsible for managing the Hanford Site's River Protection Project The River Protection Project includes all activittes required to safely store retrieve treat and dispose of Hanford Site tank wastes and to close the tank farms in which the wastes are currently stored A key objective of the River Protection Project is to establish a waste feed delivery (WFD) system that will reliably and for the least cost deliver required quantittes of tank waste feed to treatment and immobtlizatton facllittes on schedule within spectfications and in conformance with applicable safety regulatory and contract requirements

Many federal and state environmental requirements affect the establishment of a WFD system This document screens environmental requirements for potential applicability to the WFD system and presents alternatives and preferred approaches for compliance This document also identifies environmental issues that could affect the WFD system if not resolved and presents general timeframes and resource needs for different types of environmental actions

Of the environmental requirements found to be potentially applicable to the WFD system the ones that could have the most profound effects (due to complexity of implementation or significance of unresolved issues) are summarized below

- Federal and state regulations require issuance of a single site-wide Hanford Air Operating Permit (AOP) for radioactive and non-radloactive air emissions The Hanford AOP will eventually cover much of the WFD system construction and operations The Hanford AOP is nearing final approval and procedures are being developed to maintain and modify the permit In the meantime there is uncertainty about how changes to the WFD system will be addressed through permit modifications It will be necessary to coordinate resolution of Hanford AOP issues through the US Department of Energy Untll expertence is gained with implementing the Hanford AOP there will be some technical uncertainty and 
HNF-2401

Revision 1

potential for schedule delays

- Federal and state regulations require a preconstruction review and approval for any new activity process or equipment that will emit or has the potential to emit radionuclides to the air It is expected that most WFD system projects and activities will need to evaluate their work scope for compliance with the air emission standards and will require preparation and submittal of a Notice of Construction for agency review and approval Tank farms has a lot of experience with the Notice of Construction process yet because it tends to be implemented on a case-specific basis the process often retraces previous technical decisions and usually involves a major effort to complete The current process for review and approval of radionuclide air emissions is expected to impose a substantial resource and schedule burden on the WFD system Opportuntties to streamline the Notice of Construction process may be avalable and should be explored with the agencies

- Federal and state regulations also protect existing air quality from emission of nonradioactive pollutants Constructing and operating the WFD system is expected to modify existing sources of air emissions and to add new sources that do not currently extst so many projects and activities may be subject to these requirements The key significant issue is whether or not emissions of toxic air pollutants are likely to exceed regulatory limits during operation of retrieval and transfer systems Unfortunately the avallable data are insufficient for this determination so studies are being planned to predict possible toxic air pollutant emission rates and to determine what if any upgrades should be made to the existing ventilation systems In the absence of necessary data WFD system projects and activttes will have to etther proceed at risk ( $\mathrm{e}$ assume the regulations do not apply) or plan to design and procure treatment and monitoring systems to meet standards that may prove to be not applicable

- Federal and state regulations require dangerous waste treatment storage and 


\section{HNF-2401}

\section{Revision 1}

disposal facilttes to comply with stringent design and operating requirements and to obtain a permit for continued operations and closure The WFD system is subject to these standards but there are uncertainties about how to apply them to the doubleshell and single-shell tank farms Until permit negotiations are completed with the regulatory agencies it will be difficult to correctly anticipate all of the requirements that the WFD system must meet In addition depending on what permit conditions are issued modifications to the tank farms may be subject to agency and public review before they are allowed to proceed The uncertatnties assoctated with clarlfying applicable standards and making changes after a final permit has been issued could result in substantially increased risk of schedule delays and cost increases for the WFD system

- Federal regulations contain specific requirements for the management of polychlorinated biphenyls Limited knowledge about historical sources and concentrations of these compounds creates uncertainties for storage and treatment of Hanford Site tank wastes While the impacts for tank waste storage should be minimal future agency negotiations and subsequent regulatory decisions could stgnificantly impact spectfications for waste feed delivery and processes for final treatment

Other environmental requirements that may be potentially applicable to the WFD system but which are expected to have limited or manageable impacts include the following

- The National Environmental Policy Act of 1969 and the Washington State Environmental Policy Act require that potentıal environmental social and other impacts be evaluated and approprtate mitigative measures be considered before starting actions The current body of documentation appears to adequately bound the range of impacts associated with the WFD system Perlodic review and update of this documentation is expected to maintain complance with the standards 


\section{HNF-2401}

Revision 1

- A Cultural Resources Review is needed for work that could disturb potentially significant historic archaeological or other cultural resources An Ecological Compliance Review is needed if work could disturb plant or animal spectes or their habitats Blanket cultural and ecological reviews supplemented as necessary with project-speclfic and pertodic updates are expected to provide adequate coverage for WFD system activities in the tank farms

- The WFD system will require tie-ins to fresh water supplies and will probably construct or use equpment near water supply systems The Hanford Site Water Purveyor will need to review this work to ensure compliance with applicable standards and approved Hanford Site plans and spectfications

- Construction and operation of the WFD system may result in the need to dispose of waste water from hydrotesting cooling condensation, and/or stormwater collection Some disposal activities may be subject to conditions in state waste discharge permits that have been issued to the Hanford Site

- Federal and state regulations require the WFD system to practice pollution prevention and waste minimization and to provide information about hazardous substances to state and local emergency response authorttes These requirements are implemented through various tank farm and Hanford Site-wide procedures

- Unpermitted environmental releases of petroleum products hazardous substances and wastes are subject to nottfication and remediation requirements under federal and state standards It is possible that WFD system activites could encounter unexpected releases in which case Hanford Site notification and reporting procedures would be followed Remedial and/or correctlve actions would be developed and implemented in coordination with the responstble regulatory authorty 


\section{HNF-2401}

\section{Revision 1}

- A variety of other requirements may affect the WFD system such as preoperational and effluent monitoring to describe environmental conditions at and near the tank farms treatabllity study and land disposal restrictions for dangerous waste and handling practices for certain hazardous materlals (e $g$ used oul asbestos ozone depleting substances)

Potential applicability of environmental requirements as well as the significance of expected impacts may vary as retrieval and delivery strategies change the WFD system becomes better refined and new or improved information becomes avalable This document will be updated about once each fiscal year as necessary to remain current with technical and programmatic baselines incorporate resolutions of significant issues and address substantive revisions to the environmental requirements 
HNF-2401

Revision 1

This page intentionally left blank 
HNF-2401

Revision 1

\section{CONTENTS}

10 INTRODUCTION

11 SCOPE OF THE WASTE FEED DELIVERY PROGRAM 1

111 Waste Feed Composition and Quantity 3

112 Waste Feed Sources and Sequencing 4

113 Waste Feed Delıvery Supportıng Projects and Actıvities 4

12 METHOD AND CONTENT OF THIS PLAN 11

20 ENVIRONMENTAL POLICY, PLANNING, AND ASSESSMENT

21 FEDERAL AND STATE ENVIRONMENTAL POLICY ACTS 15

211 National Environmental Policy Act of 1969

212 State Environmental Policy Act 16

213 Alternatives for Satısfying Applicable NEPA And SEPA Requirements 16

214 Recommended Approaches for Complying with NEPA and SEPA 17

215 Significant NEPA/SEPA Issues 18

22 CULTURAL RESOURCES AND ECOLOGICAL COMPLIANCE REVIEWS 18

221 Alternatives for Satısfying Applicable Cultural/Ecological Requirements 18

222 Recommended Approaches for Complyıng with Cultural/Ecological $\begin{array}{ll}\text { Requirements } & 19\end{array}$

223 Significant Cultural/Ecological Issues 19

23 PRE-OPERATIONAL MONITORING OF FACILITIES, SITES, AND OPERATIONS 19

231 Alternatives for Performing Pre-Operational Monitoring 20

232 Recommended Approach for Pre-Operational Monitoring 20

233 Significant Pre-Operational Monitoring Issues 20

24 EXCAVATION PERMIT 20

25 DOE ACQUISITION/ENVIRONMENT, SAFETY AND HEALTH MANAGEMENT $\quad 21$

30 AIR EMISSIONS 23

31 HANFORD SITE AIR OPERATING PERMIT 23

311 Alternatıves for Satısfying Hanford Air Operatıng Permit Conditions 23

312 Recommended Approach for Hanford Aır Operatıng Permit Compliance 24

313 Significant Hanford AOP Issues 24

32 RADIOACTIVE AIR EMISSIONS 24

321 Alternatıves for Satısfying Radıoactıve Aır Emıssions Standards 25

322 Recommended Approach for Radioactıve Air Emissions Compliance 26

323 Significant Radıactive Air Emissions Issues 27

33 NON-RADIOACTIVE AIR EMISSIONS 27

331 Alternatıves for Satısfyıng Non-Radıactıve Air Emıssions Standards 28

332 Recommended Approach for Non Radioactive Air Emıssions Compliance

333 Stgnificant Non-Radioactıve Air Emissions Issues 29

40 WATER AND WASTE WATER MANAGEMENT 31

41 DRINKING WATER SYSTEMS 31

42 STATE WASTE DISCHARGE PERMIT 31 
HNF-2401

Revision 1

50 RADIOACTIVE MATERIALS AND WASTE MANAGEMENT 33

60 SOLID AND DANGEROUS WASTE MANAGEMENT

61 WASTE OILS

62 DANGEROUS WASTE TREATMENT, STORAGE, AND DISPOSAL FACILITIES 35

621 Interım and Final Status Standards 35

622 Recommended Approach for Dangerous Waste Treatment, Storage, and Disposal Facility Compliance 36

623 Significant Dangerous Waste Treatment, Storage, and Disposal Facility Issues

63 MISCELLANEOUS REQUIREMENTS FOR DANGEROUS WASTE MANAGEMENT

70 HAZARDOUS SUBSTANCES 39

71 OZONE DEPLETING SUBSTANCES 39

72 ASBESTOS 39

73 POLLUTION PREVENTION, WASTE MINIMIZATION, COMMUNITY RIGHT-TO-KNOW NOTIFICATION AND REPORTING 39

74 NOTIFICATION AND REMEDIATION OF ENVIRONMENTAL RELEASES 40 75 POLYCHLORINATED BIPHENYLS 41

80 REFERENCES

\section{APPENDICES}

A ENVIRONMENTAL PERMITS, APPROVALS AND REQUIREMENTS CHECKLIST AND NARRATIVE FOR THE WASTE FEED DELIVERY SYSTEM

B ESTIMATED LEVELS OF EFFORT FOR ENVIRONMENTAL PERMITS AND APPROVALS FOR THE WASTE FEED DELIVERY SYSTEM

\section{FIGURES}

Figure 1 Privatization Phase 1 Low-Actıvity Waste Feed Sources and Delivery Sequence 5

Figure 2 Privatization Phase 1 High Level Waste Feed Sources and Delivery Sequence 6

Figure 3 Privatization Phase 1 Waste Feed Delivery Transfer Routes and Facilities 7

Figure 4 Projects Supportıng Privatızation Phase 1 Waste Feed Delıvery System 8

\section{TABLES}

Table 1 Privatization Phase 1Waste Feed Envelope Descriptions 3

Table 2 Privatization Phase 1 Estımated Waste Feed Order Quantities 4 
HNF-2401

Revision 1

\section{LIST OF TERMS}

AKART

ALARA

ALARACT

AOP

ASIL

BARCT

BCAA

BIA

BMP

CAA

CERCLA

CFR

$\mathrm{CHG}$

CX

DOE

DST

EA

Ecology

ECO

EIS

EMP

EPA

EPCRA

EReqs

FDH

FEMP

FIFRA

FONSI

FR

FY

GWQC

HCRL

HLW

HNF

HWMA
All known, avalable, and reasonable treatment

As low as reasonably achievable

As low as reasonably achievable control technology

Air operatıng permit

Acceptable source impact level

Best avalable radionuchde control technology

Benton Clean Air Authority

Bureau of Indian Affairs

Best management practice

Clean Atr Act

Comprehensive Environmental Response Compensation and Liability Act

Code of Federal Regulations

CH2M HILL Hanford Group Inc

Categorical exclusion

U S Department of Energy

Double-shell tank

Environmental assessment

Washıngton State Department of Ecology

Environmental compliance officer

Environmental impact statement

Environmental monitoring plan

U S Environmental Protection Agency

Emergency Planning and Community Right-to-Know Act

Environmental requirements

Fluor Daniel Hanford, Inc

Facility effluent monitoring plan

Federal Insecticide Funglctde and Rodenticide Act

Finding of no significant impact

Federal Register

Fiscal year

Ground water qualıty criterıa

Hanford Cultural Resource Laboratory

High-level waste

Hanford Nuclear Facility (document 1dentıfier)

Washington State Hazardous Waste Management Act 
HNF-2401

Revision 1

IEU

ISMS

LAW

LLW

MPS

MTCA

NEPA

NESHAPs

NOC

NPDES

NSR

ORP

PAAA

PCB

PL

PNL

PNNL

ppm

PSD

RCRA

RL

ROD

RPP

SEIS

SEPA

SST

SWDP

TAPs

T-BACT

Tr1-Party

Agreement

TRU

TSCA

TSD

TWRS

TWRSO\&UP
Insignificant emission units

Integrated Environment, Safety and Health Management System

Low-activity waste

Low-level waste

Master pump shutdown

Washington State Model Toxics Control Act

National Environmental Policy Act of 1969

National Emissions Standards for Hazardous Air Pollutants

Notice of construction

National Pollutant Discharge Elımination System

New source review

U S Department of Energy, Office of River Protection

Price Anderson Amendments Act

Polychlorinated biphenyl

Public Law

Pacific National Laboratory

Pacific Northwest National Laboratory

Parts per million

Prevention of significant deterioration

Resource Conservation and Recovery Act of 1976

U S Department of Energy, Richland Operations Office

Record of decision

River Protection Project

Supplemental environmental impact statement

Washington State Environmental Pollcy Act

Single-shell tank

State waste discharge permit

Toxic arr pollutants

Best avallable control technology for toxics

Hanford Federal Factlity Agreement and Consent Order

Transuranic (material/elements/waste)

Toxic Substances Control Act

Treatment, storage, and/or disposal

Tank Waste Remediation System

Tank Waste Remediation System Operatıon and Uttlization Plan 
HNF-2401

Revision 1

USACE

USFWS

UST

WAC

WDOH

WFD

U S Army Corps of Engineers

U S Fish and Wildlife Service

Underground storage tanks

Washington Administratıve Code

Washıngton State Department of Health

Waste feed delivery 
HNF-2401

Revision 1

This page intentionally left blank 
HNF-2401

Revision 1

\section{WASTE FEED DELIVERY ENVIRONMENTAL PERMITS AND APPROVALS PLAN}

\section{INTRODUCTION}

This plan describes the environmental permits, approvals and other requirements that may affect establishment of a waste feed delivery (WFD) system for the Hanford Site's River Protection Project (RPP) This plan identıfies and screens environmental requirements for potentıal applicability, outlınes alternatıves for satısfyıng applicable standards, describes preferred permittıng and approval approaches, and provides information about schedule and resource assumptions for environmental planning The information in this plan is intentionally broad-based and encompasses a more comprehensive range of permits and approvals than would apply to any single project or activity This approach provides a more complete perspective for assessing environmental issues that affect the WFD system, thus improving the consistency, long term reliability and overall relevance of recommended compliance strategies It is expected that more detailed environmental permits and approvals plans (or equivalent documents) will be developed, as needed to address the unique conditions and variety of events that will be encountered on a project and activity-specific basis Project- and activity-specific plans can define more detalled approaches (including schedules and resource needs) to acquirnng environmental permits and approvals and adapt the programmatic strategies developed in this plan to their particular compliance needs

\section{SCOPE OF THE WASTE FEED DELIVERY PROGRAM}

The U S Department of Energy Office of River Protection (ORP) is responsible for managing all aspects of the RPP The RPP includes all activities requrred to safely store, retrieve, treat and dispose of Hanford Site tank wastes and to close the tank farms in which the wastes are currently stored A two-phased approach has been developed for treatment and immobilization of tank waste by a private contractor Privatization Phase 1 will assess the effectiveness of systems and technologies for treatıng and immobilizing an initial volume of tank wastes and Privatization Phase 2 will involve full-scale processing of the remaining wastes Privatization Phase 1 is expected to extend as late as calendar year 2018 The ORP's current private contractor selection is BNFL Inc

CH2M HILL Hanford Group, Inc (CHG) is responsible for many RPP functions The description of work in the Tank Waste Operations contract (ORP 1999) states that CHG shall conduct business consistent with the following objectives, which flow from the Hanford Strateglc Plan (RL 1996)

- Maintain tank farms in a safe and stable configuration

- Retrieve tank wastes to the extent needed for tank closure and deliver to the privatization contractor for treatment and immobilization 
HNF-2401

Revision 1

- The immobilized low-activity fraction will be disposed onsite in a 200 Area disposal system

- The high level ımmobilized fraction will be interım stored untıl it can be shipped offsite for disposal

- Incorporate the cesium/strontium capsules declared as waste into the high-level waste (HLW) process for repository disposal

- Retrieve Hanford tank waste and permanently close all Hanford tank farms

Within CHG, the tank waste retrieval and disposal mission includes activities to develop necessary infrastructure, retrieve tank wastes and deliver waste feed, store and disposition immobilized waste and close the tank farms

CHG is developing a WFD system that can retrieve selected tank wastes, stage the wastes to meet contractually defined waste feed specifications, and deliver the wastes as feed to BNFL Inc facilities for treatment and immobilization For now, the primary focus of the WFD system is on supporting Privatization Phase 1 although the WFD mission also includes assisting with an efficient and effective transition between Privatization Phases 1 and 2 Initial waste feed deliveries are expected to begin as early as calendar year 2005, pretreatment of delivered feed is expected to begin as early as calendar year 2006, and vitrification is expected to begin as early as calendar year 2007 The earliest date by which BNFL Inc could potentially finssh processing the minimum required quantities of Privatization Phase 1 wastes (referred to in this plan as the "Minımum Order") is in calendar year 2012 During the rest of Privatızation Phase 1 (up to six years) the ORP can request BNFL Inc to process additional waste feed (referred to in this plan as the "Extended Order")

The mission of the WFD system is to reliably and for the least cost deliver required quantities of tank waste feed to treatment and immobilization facilities on schedule within specifications, and in conformance with all applicable regulatory, safety, and contractual requirements Key Privatization Phase 1 objectives that the WFD system must meet include

- Establish a waste feed strategy that identifies the source tanks timing and order of waste retrieval and waste transfer processes for delivery of tank wastes on time and within envelope specifications, to BNFL Inc

- Identify, define, and specify the systems, structures, components and activities needed to implement the waste feed strategy

- Scope, plan fund, perform and monitor projects and activities needed to refurbish, construct, install test, turn over, operate, and maintain the equipment and facilities for accomplishing WFD durıng Privatızation Phase 1 
HNF-2401

Revision 1

The objectives outlined above will be accomplished in ways that are consistent with other tank farm responsibilitıes (e g , safety and watch-list tanks, safe operatıon, maintainıng adequate double-shell tank [DST] capacity) and that help support future transition to Privatization Phase 2 The following sections provide summary level information concerning composition of the planned waste feeds, planned sources and sequencing of the waste feeds, and the facility projects and equipment upgrades needed to establish the WFD system

\section{Waste Feed Composition and Quantity}

The current approach to Privatızatıon Phase 1 involves demonstratıng treatment capabilities for four types of waste feed referred to as envelopes A, B, C, and D Envelopes A, $B$, and $C$ provide three low-activity waste (LAW) feed variations, while envelope D is a HLW feed These envelopes are described in Table 1 During Privatization Phase 1, BNFL Inc is expected to be able to process a Minimum Order of LAW and HLW waste feeds, and the ORP may also request BNFL Inc to process an Extended Order Table 2 summarizes the estımated Minımum and Extended Order quantıties currently planned for the WFD system to deliver Envelopes and order quantities are subject to change as characterızation data improves, and as delivery, treatment, and immobilization systems are refined TWRS Privatization (RL 1998) establishes the detalled specifications for the waste feed envelopes and order quantities

Table 1 Privatization Phase 1Waste Feed Envelope Descriptions

\begin{tabular}{|c|l|}
\hline Envelope & \multicolumn{1}{|c|}{ Description* } \\
\hline A & $\begin{array}{l}\text { Waste that will test the production capacity and fission product removal efficiency } \\
\text { while producing a final product in which waste loadıng will be limited by sodium }\end{array}$ \\
\hline B & $\begin{array}{l}\text { Waste similar to Envelope A but that will produce a final product in which the } \\
\text { waste loading will be limited by minor component concentrations }\end{array}$ \\
\hline C & $\begin{array}{l}\text { Waste with complexing agents that may interfere with } \\
\text { decontamination requiring demonstration of organic destruction or some other } \\
\text { acceptable mitigation technology }\end{array}$ \\
\hline D & $\begin{array}{l}\text { Waste that contains insoluble solids classified as high-level waste The envelope } \\
\text { approximates solids content in three existing double-shell tanks, 24l-AZ-101, } \\
241-\mathrm{AZ}-102, \text { and 241-AY-102 (including sluiced and transferred contents of } \\
241-\mathrm{C}-106)\end{array}$ \\
\hline
\end{tabular}

*Adapted from Tank Waste Remediatıon System Operation and Utilization Plan

(Kirkbride et al 1999) See TWRS Privatization (RL 1998) for contract envelope specifications 
HNF-2401

Revision 1

Table 2 Privatization Phase 1 Estımated Waste Feed Order Quantities

\begin{tabular}{|c|c|c|c|c|}
\hline \multicolumn{2}{|c|}{ Waste feed } & Minımum order* & Extended order* & Total* $^{*}$ \\
\hline \multirow{2}{*}{$\begin{array}{c}\text { Low-actıvity waste } \\
\text { (Metric Tons of Sodıum) }\end{array}$} & $\mathrm{A}$ & 4,450 & 3,600 & 8,050 \\
\cline { 2 - 5 } & $\mathrm{B}$ & 650 & 0 & 650 \\
\hline $\begin{array}{c}\text { High-level waste } \\
\text { (Metric Tons of Solıds) }\end{array}$ & $\mathrm{C}$ & 1,600 & 0 & 1,600 \\
\hline
\end{tabular}

*Approximate quantities as of November 1999, estımates subject to change as the

Waste Feed Delivery system matures and waste characterization and inventory data improve

See TWRS Privatizatıon (RL 1998) for contract order quantity specifications

\section{Waste Feed Sources and Sequencing}

The source tanks, retrieval sequence, and order for waste feed delivery are selected to be consistent with contract envelope specifications and order quantities Other key influences on source and sequence selection include ongoing waste management activities (e g receipt of remediation waste, salt well pumping single-shell tank (SST) retrieval, transfers to and from 242-A Evaporator), and the need to maintain acceptable excess DST storage capacity Figure 1 shows planned source tanks and feed sequencing for LAW durıng Privatization Phase 1 Figure 2 presents the same information for HLW feeds The current sources and sequencing are subject to change depending on RPP needs and priorities, ORP direction, characterization data improvements and WFD system refinement The Tank Waste Remediatıon System Operation and Utilization Plan (TWRSO\&UP) (Kırkbride et al 1999) provides additional detal on sources sequencing, and other operating scenario information accounted for in developing the WFD system

\section{Waste Feed Delivery Supportıng Projects and Actıvities}

Waste feed will be retrieved from source tanks, transferred to staging tanks tested for contract and other requirements ( $\mathrm{g}$, envelope specifications), and transferred to BNFL Inc Figure 3 shows transfer routes and facilities currently planned to support mobilization of the waste and delivery of LAW and HLW feed The process configuration depicted on Figure 3 is prelıminary at this time pending final contract and programmatic direction from ORP Additional information about the configuration of the WFD system can be found in River Protection Project Tank Waste Retrieval and Disposal Mission Technical Baseline Summary Description (Friberg et al 1999), Waste Feed Delivery Technical Basts Document (Rasmussen 1998), and the TWRSO\&UP (Kırkbride et al 1999)

For purposes of this plan, it is expected that most environmental permits, approvals, and compliance issues will arise as a result of the construction projects and major activities needed to support development of the WFD system Current and known future projects are depicted in Figure 4, and their scopes of work and starts of construction are summanzed below 
HNF-2401

Revision 1

\section{Figure 1 Privatızation Phase 1 Low Actıvity Waste Feed Sources and Delıvery Sequence}

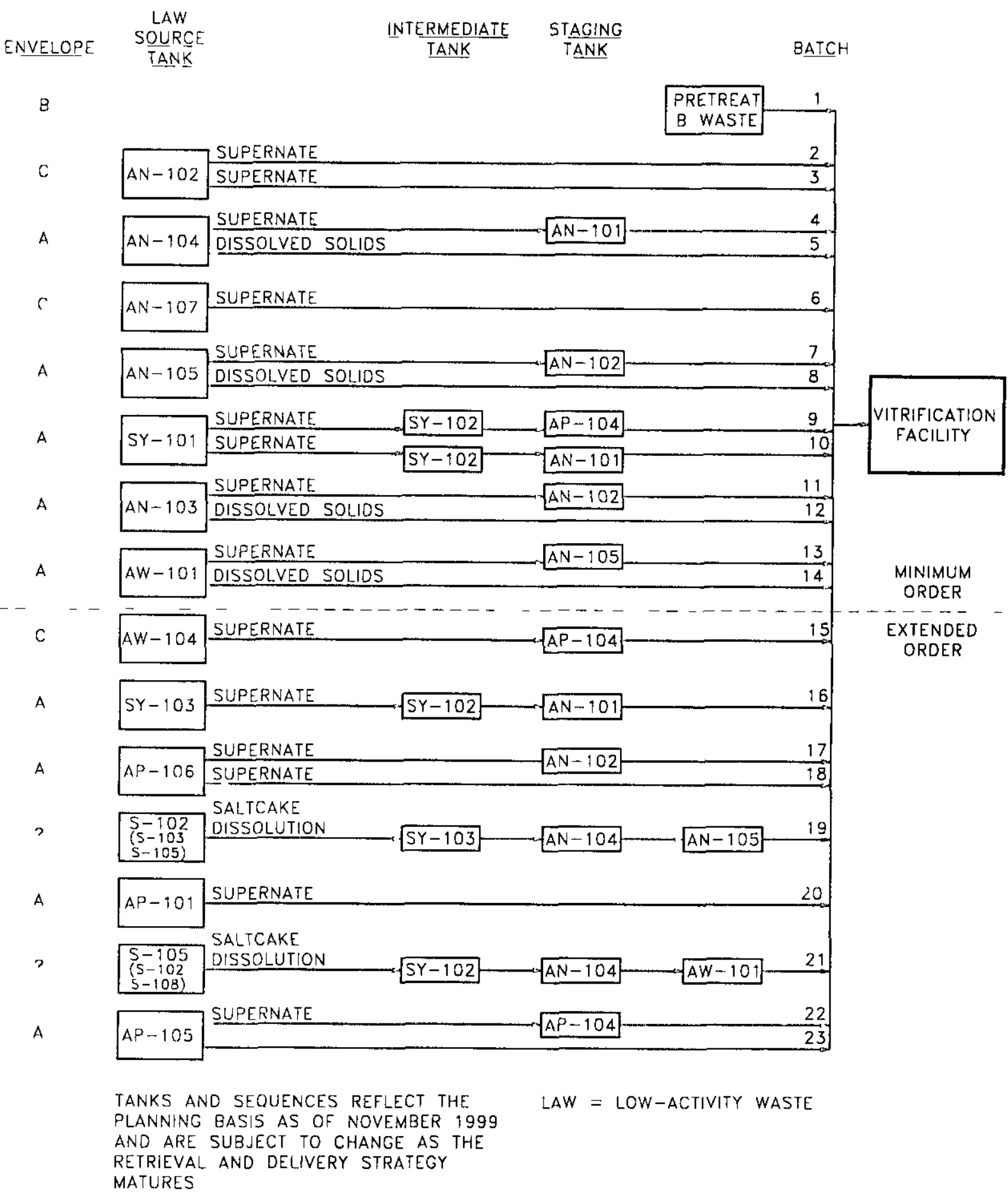


HNF-2401

Revision 1

Figure 2 Privatization Phase 1 High-Level Waste Feed Sources and Delivery Sequence

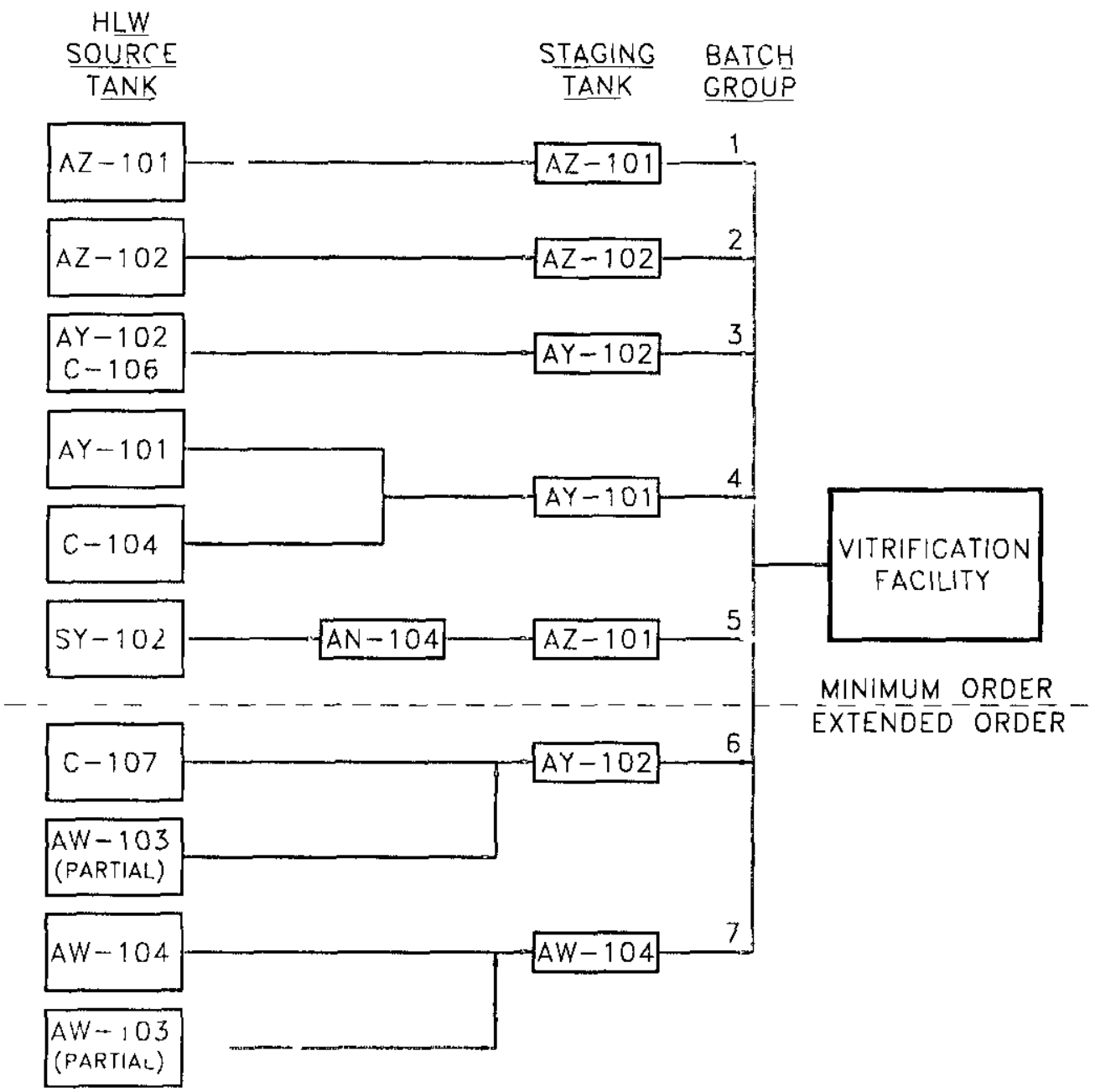

TANKS AND SEQUENCES REFLECT THE

PLANNING BASIS AS OF NOVEMBER 1999

$H L W=H I G H-L E V E L$ WASTE

AND ARE SUBJECT TO CHANGE AS THE

RETRIEVAL AND DELIVERY STRATEGY

MATURES 


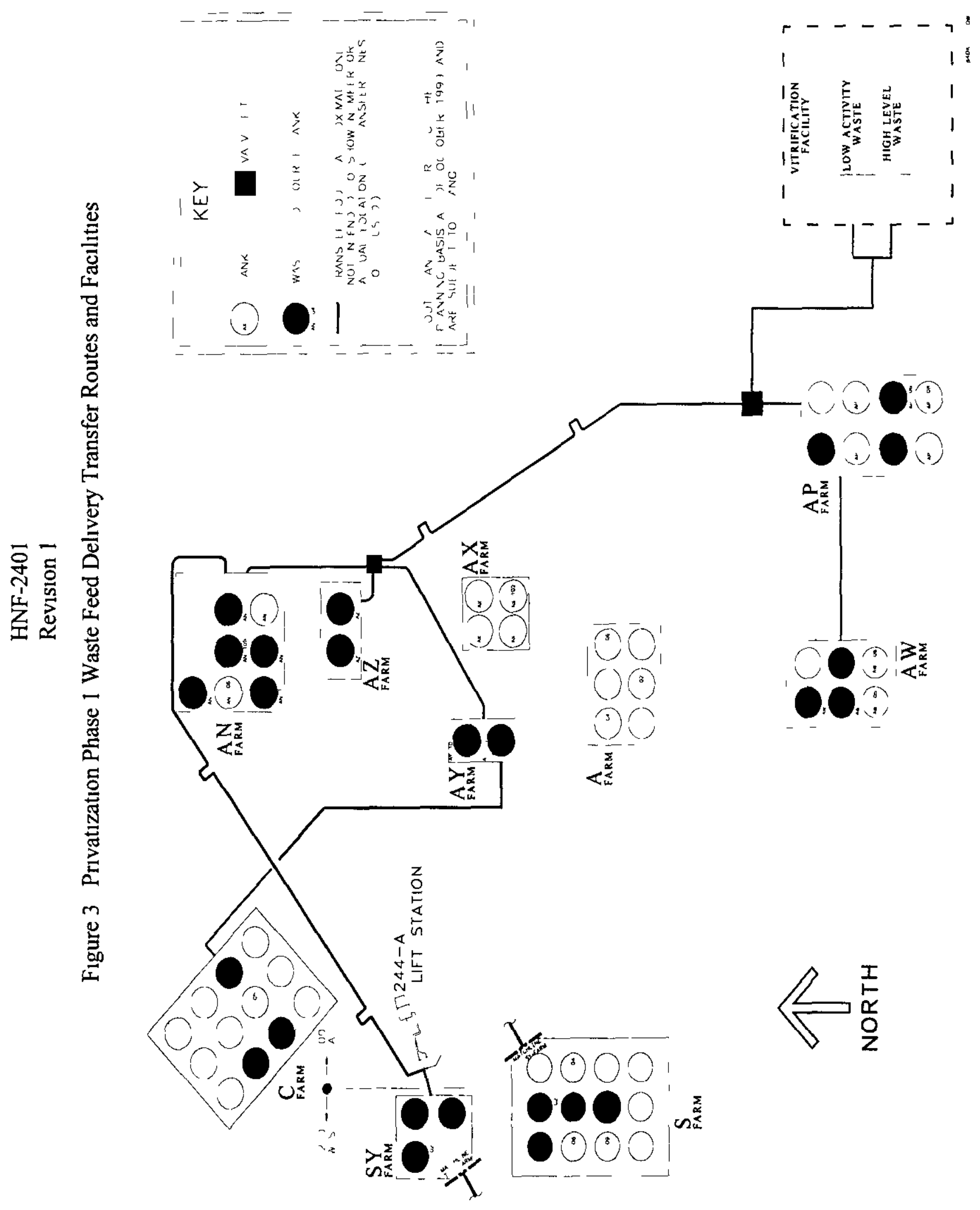




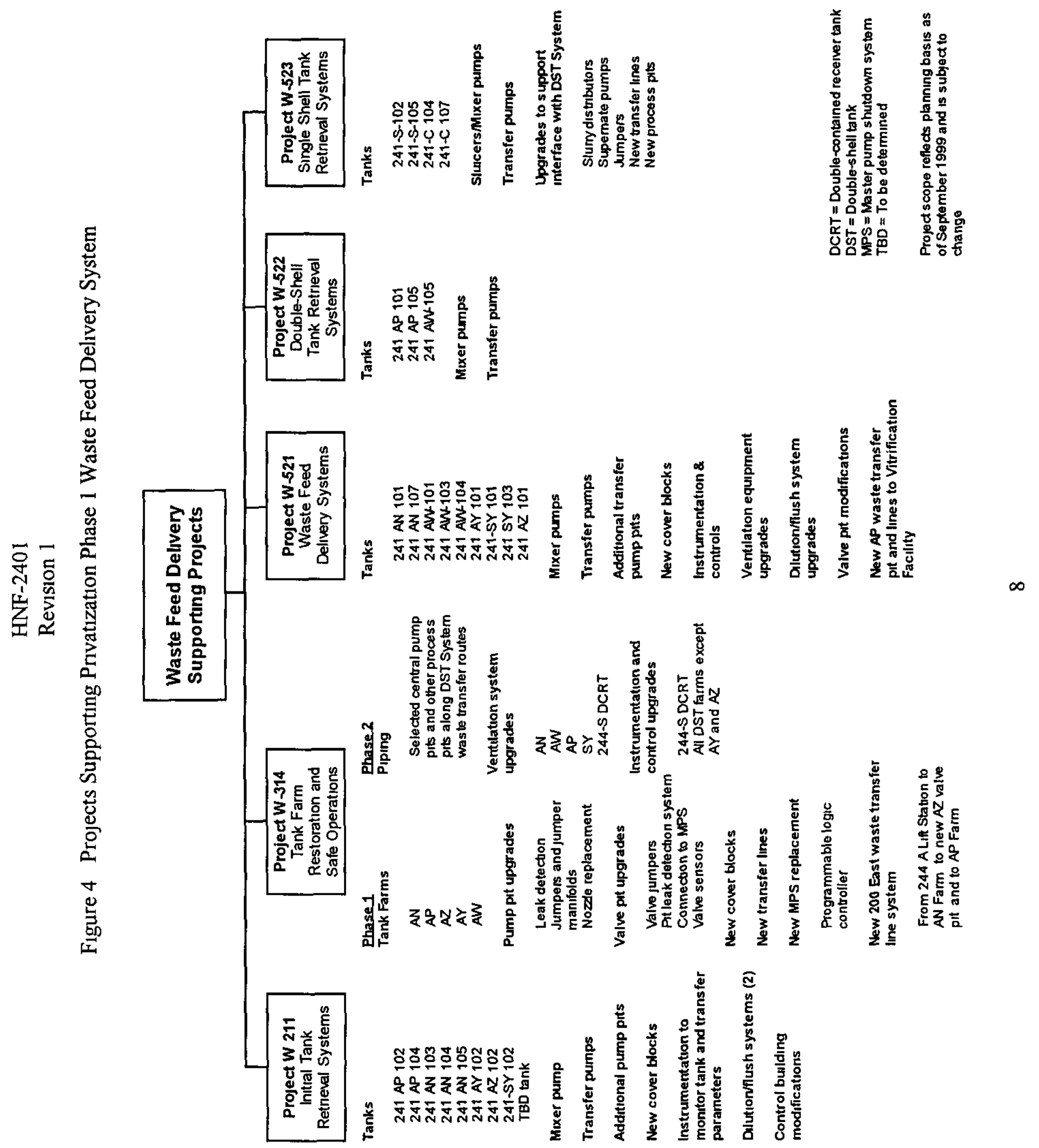


Project scopes and schedules are subject to change, based on programmatic needs and priorities, project refinement, and avallability of funding

Project W-211 - Inıtıal Tank Retrieval Systems Project W-211 supports tank waste treatment and disposal by providing equipment for feeding waste to BNFL Inc This project will procure and install systems for retrieval of waste from nine DSTs in the AN, AP, AY AZ, and SY tank farms The tank wastes are a combination of supernatant liquids and settled solids, which must be mixed pror to transfer As required for each retrieval system, project scope may include installation of mixer pumps, transfer pumps additional pump pits new cover blocks, instrumentation to monitor tank and transfer parameters, as well as instrumentation necessary to interface with existing tank instrumentation Two dilution/flush systems will be provided one located near AP Tank Farm, and one near AN Tank Farm The AN Tank Farm dilution/flush system will also serve the $A Z$ and $A Y$ Tank Farm retrieval systems Control building modifications and upgrades including a new control buldıng near AY Tank Farm, will be provided to house retrieval control systems and electrical equipment Project scope also includes removal of in-tank components necessary to support installation of new assemblies Construction is scheduled to begin by October 2000, with completion in March 2010

\section{Project W-314 - Tank Farm Restoration and Safe Operations, Phase 1 Project} W 314 Phase 1 will restore and/or upgrade existing DST system facilities to ensure that the tank farm infrastructure will be able to support waste feed delivery requirements and continued safe management of tank waste The project has been divided into two phases Phase 1 includes installation of new, or upgrades to existing piping and transfer systems, instrumentation and control systems, and facility structures, as well as upgrades, replacements, and tie-ins to the existing master pump shutdown (MPS) system Project W-314, Phase 1 includes work in the AN, AP, AZ AY, and AW Tank Farms As required for each system project scope may include transfer lines with encasement, cathodic protection, leak detection systems, jumpers and jumper manifolds, valves and nozzles drain valve operators valve position systems cover blocks protective coatıngs for pits and covers electrical power and instrumentation, and other related upgrades Project W-314, Phase 1 will also provide a new 200 East Area waste transfer line system Slurry and supernate transfer lines will be installed, bypassing older, less reliable piping and routing wastes around the tank farms through new, fully compliant piping Construction began in fiscal year (FY) 1998 and is scheduled to be complete in FY 2003

Project W-314 - Tank Farm Restoration and Safe Operations, Phase 2 Project W-314 Phase 2 will support future waste storage, retrieval, and feed staging operations and selected regulatory compliance upgrades Scope includes upgrades to piping, ventilation and electrical systems Selected central pump pits and valve pits/diversion boxes along the waste transfer routes for DSTs will be cleaned decontaminated, and upgraded with protective coatıng New pit drain valves and leak detectors will be provided in some pits Upgrades will be made to the primary ventilation systems for AN, $\mathrm{AP}$ and AW Tank Farms the annulus ventilation systems for the SY Tank Farm, and the $244 \mathrm{~S}$ double contaned receiver tank ventilation system The project will replace motor control centers and vent and heater control panels with new units in the AY and AZ Tank 
HNF-2401

Revision 1

Farms and upgrade and/or provide backup power capability for the primary ventilation system and stack monitors for AN, AP and AW Tank Farms The project will also provide corrosion protection for new transfer piping and install spare main circuit breakers for AN and AW Tank Farms Construction is scheduled to begin in FY 2000 with completion in FY 2005

Project W-521 - Waste Feed Delivery Systems The purpose of Project W-521 is to provide equipment and systems needed to deliver waste feed to BNFL Inc This project will procure and install equipment necessary to $\mathrm{mix}$ and/or retrieve waste from nine DSTs in the AN, AW, AY, AZ, and SY tank farms As required for each system, project scope may include installation and/or replacement of mixer pumps, transfer pumps, transfer piping, jumpers, nozzles caustic diluent and flush systems, cover blocks, ventilation system upgrades instrumentation and controls Project W-521 also includes scope to install a new transfer pit near the AP Tank Farm which will provide the physical interface for waste feed transfers to the BNFL Inc facilities Associated transfer lines, leak detection systems, corrosion protection, MPS tie-1ns, valving instruments, and controls will be provided by the project as well Construction is scheduled to begin October 2001 with completion in June 2006

Project W-522 - Double-Shell Tank Retrieval Systems The purpose of Project W-522 is to provide mixing and pumping capabilities as necessary to complete retrieval system upgrades to the remaining DSTs Based on current scope and planning for the WFD system, it is expected that this project will procure and install in-tank and supporting equipment upgrades in the $\mathrm{AP}, \mathrm{AW}$, and $\mathrm{SY}$ tank farms In-tank equipment will be provided to mobilize settled solids and transfer waste out of tanks for staging and delivery to BNFL Inc Construction is scheduled to begin October 2006 with completion in June 2015

Project W-523 - Single-Shell Tank Retrieval Systems The purpose of Project W-523 is to provide waste retrieval systems for SSTs that have been identified as source tanks for Privatization Phase $1 \mathrm{HLW}$ feed SST contents include a combination of supernatant liquids and settled solids which must be mixed prior to transferring the waste The project scope includes providing in-tank and supportıng equipment upgrades to selected SSTs in the $\mathrm{C}$ and $\mathrm{S}$ tank farms This project also includes upgrades to the DST System to support receipt of waste retrieved from the SSTs As required for each SST retrieval, project scope may include slurry distributors supernate pumps transfer lines process pits, jumpers, valving instruments and controls Construction is scheduled to begin September 2006 with completion in September 2013

Additional information on current work scope, environmental planning, and permitting bases for major projects supporting the WFD system can be found in various documents, including the following 
HNF-2401

Revision 1

- Functıonal Design Criterla Project W-211 Inttıal Tank Retrieval Systems (Rieck 1997)

- Interface Document, Project W 211 Initıal Tank Retrieval Systems (Rıeck 1998)

- Conceptual Design Report for Tank Farm Restoration and Safe Operations Project $W-314$ (Boes 1996)

- Tank Farm Restoration and Safe Operation Project W-314 Upgrade Scope Summary Report (USSR) (Grlbert 1998)

- Project W-314 Phase I Environmental Permits and Approvals Plan (Papp et al 1998)

- Project Definition Criteria for Project W-521 Waste Feed Delivery Systems (Brackenbury 1999a)

- Scope Analysts Report for Project W-521 Waste Feed Delivery Systems (Brackenbury 1999b)

- Project W-521 Waste Feed Delivery Systems Environmental Permits and Approvals Plan (Tollefson 1999)

- TWRS Environmental Permits and Related Documentation (Dexter 1999)

\section{METHOD AND CONTENT OF THIS PLAN} as follows

The method for developing the information and recommendations provided in this plan is

Applicability Screening An environmental requirements (EReqs) checklist, identıfyıng known environmental requirements, is used to help determine which permits approvals, and compliance actions may potentially be applicable during development of the WFD system (as currently configured) The applicability determinations are documented in the EReqs checklıst, and the rationale for each decision is explained in an accompanying EReqs narratıve

Alternatives Several alternatives may be avalable for implementing an applicable environmental standard, each with its own advantages and disadvantages for the WFD system Some alternatives could be implemented system-wide, while others would be carried out at a project- or activity-specific level Permitting and comphance alternatives must be evaluated for consistency with the overall RPP mission, the objectives of the WFD system, and the project- or activity-specific needs The alternatives evaluation seeks the best balance for required environmental actions, and helps identify opportunities to integrate environmental permitting and compliance across all projects and activities within the RPP 
HNF-2401

Revision 1

Recommended Approaches In some cases, a preferred alternative can be recommended as the best overall approach for satisfying an applicable environmental standard This would be the permitting or compliance approach implemented for most projects or activities supporting the WFD system The other alternatıves may still be avallable and could be implemented instead for the few circumstances in which the recommended approach was not appropriate or fully useful

Significant Issues The abılity to determine how best to satısfy envıronmental standards may be limited by uncertainties about interpretıng the standards or about the final configuration of the WFD system Environmental issues that could significantly affect the WFD system must be identified and resolved In the meantime, reasonable assumptions must be made so that WFD system development can proceed, and potential risks and impacts associated with the uncertainties must be anticipated so cost and schedule contingencies can be planned

The main body of this plan focuses on potentially applicable environmental standards (identified by the EReqs applicability screening) and is organized into the following topical sections

20 Environmental Policy, Planning and Assessment This section addresses the need to consider overall environmental policy, cultural and social impacts of the WFD system

30 Air Emissions This section addresses the need to minimize and control atmospheric emissions of radiological and chemical constituents from the WFD system

40 Water and Waste Water Management This section addresses requirements for WFD system water supplies and waste water discharges to ground

50 Radıoactive Materials and Waste Management This section addresses requirements for protecting against potential radiation exposures from the WFD system

60 Soldd and Dangerous Waste Management This section addresses the need to properly manage solid and dangerous wastes from the WFD system

70 Hazardous Substances This section addresses additional requirements that apply to managing and reporting about selected hazardous substances withın the WFD system

80 References Provides a listing of references cited in this plan

Each of these sections (except for the references) begins with a summary of the potentially applicable environmental standards and associated permit and approval processes Avarlable permitting and compliance alternatıves are identified, along with recommended approaches (where appropriate) for satısfying the applicable requirements Permitting and compliance issues are briefly described if potential impacts on the WFD system could be significant 
HNF-2401

Revision 1

Appendix A provides the EReqs checklıst and narratıve for the WFD system, documenting the environmental standards applicability determinations and rationale Appendix B presents general timeframes and resource commitments associated with different types of environmental actions This information is provided to assist project planners with developing schedules and resource estımates to assure timely completion of environmental permittıng and compliance work 
HNF-2401

Revision 1

This page intentıonally left blank 
HNF-2401

Revision 1

\section{ENVIRONMENTAL POLICY, PLANNING, AND ASSESSMENT}

The federal National Environmental Policy Act of 1969 (NEPA) was enacted to ensure that potential environmental social, and other impacts are evaluated, and appropriate mitigative measures considered before federal actions are initıated that might affect the quality of the human environment The Washington State Environmental Policy Act (SEPA) is sımilar in effect to NEPA, and requires evaluation of environmental impacts associated with a project or an agency action before approval of the project or action is granted In addition to these overarching environmental policy programs, there are several other environmental planning and assessment requirements that could affect the WFD system

\section{FEDERAL AND STATE ENVIRONMENTAL POLICY ACTS}

\section{National Environmental Policy Act of 1969}

The NEPA standards require that environmental considerations be identıfied and evaluated early in the planning process for proposed federal actions Proposed Hanford Site actions have NEPA determinations completed before actions commence and NEPA documentation is completed before starting Title II Design or long lead procurements DOE accomplishes the NEPA compliance review by preparing an Environmental Impact Statement (EIS) or an Environmental Assessment (EA), or by issuing a categorical exclusion (CX) if the proposed action clearly has no significant impact on the quality of the human environment The DOE NEPA Compliance Officer approves the correct level of NEPA review for the Hanford Site

Many of the actions associated with developing and implementing the WFD system have been anticipated and addressed in existing NEPA documentation, including the following

- A listıng of NEPA site-wide CXs for the Hanford Site is avallable electronically on the Internet at http //www rl gov/wastemgt/nepa/swcx/swcx html

- Safe Interim Storage of Hanfords Tank Waste Final Environmental Impact Statement (DOE 1995)

- "Record of Decision for Safe Interım Storage of Hanford Tank Wastes" (60 FR 61687)

- Tank Waste Remediation System Hanford Site Richland Washington Final Environmental Impact Statement (DOE 1996)

- Record of Decision for the Tank Waste Remediation System' (62 FR 8693) 
HNF-2401

Revision 1

- Supplement Analysis for the Proposed Upgrades to the Tank Farm Ventilation Instrumentation and Electrical Systems Under Project W-314 in Support of Tank Farm Restoration and Safe Operattons (DOE 1997a)

- Supplement Analysis for the Tank Waste Remediation System (DOE 1998a)

- Hanford Stte Tank Waste Remediation System Programmatic Environmental Review Report (DOE 1998b)

Related NEPA documentation exists in various other EAs and EISs, which have been summarized by Fluor Daniel Hanford, Inc, in NEPA Source Gulde for the Hanford Site (FDH 1998)

\section{State Environmental Polıcy Act}

The SEPA standards require evaluation of a project's environmental impacts before it can receive state or local permits or approvals A SEPA checklist is completed to identify potential impacts and the lead agency (usually the imitial permitting authority) decides whether an EIS is required or if a determination of non-significance can be 1ssued An EIS or EA developed under NEPA may substitute (at the option of the lead agency) for the SEPA checklist, and the lead agency can defer to existing NEPA documentation in lieu of independent SEPA documentation Past experience has been that the Washington State Department of Ecology (Ecology) is usually the lead agency for SEPA decisions at the Hanford Site, and that in most cases Ecology has been comfortable in accepting existing NEPA documentation as sufficient under SEPA

\section{Alternatıves for Satısfyıng Applicable NEPA And SEPA Requirements}

Alternatıves to be considered for assuring NEPA compliance include the following

- Prepare a new EIS or supplemental EIS An EIS is warranted if it is determined that a proposed action will have impacts to the human environment that might be significant and which have not been adequately bounded in previous EIS information

- Prepare a Supplement Analysis A Supplement Analysis is warranted if there are substantial changes or potentially significant new circumstances or information relevant to environmental concerns for an action covered by an existing EIS

- Prepare an EA An EA analyzes the environmental consequences of a proposed action and the alternatives to that action, and is prepared when there is uncertainty about the need for an EIS The EA is a precursor to deciding whether an EIS, finding of no significant impact, or further study is necessary 
HNF-2401

Revision 1

- Issue a CX If a proposed action falls within a category of actions not normally requirıng an EA or an EIS, the action may be eligible for a CX Site-wide CXs are applied to various types of activities specific to the Hanford Site

- Rely on existing NEPA documentation The avallable body of EISs, EAs, records of decision, and other NEPA documentation can be relied on if it adequately bounds the range of impacts associated with a proposed action

Alternatives to be considered for assurıng SEPA compliance include the following

- Prepare a SEPA checklist and an EIS A SEPA checklist and EIS may be warranted If the lead agency determines the environmental impacts of a proposed action require further evaluation and mitigation

- Prepare a SEPA checklist and obtain a determination of non-significance If a proposed action would have minımal environmental impacts, a SEPA checklist could be submitted with enough information to allow the lead agency to issue a determination of non significance

- Rely on existing NEPA documentation Reliance on NEPA documentation would be warranted as long as the NEPA process considered the range of environmental impacts and mitıgatıve measures for a proposed project to at least the same extent as required by the SEPA standards In this approach, it would be advisable to seek concurrence of the SEPA lead agency

\section{Recommended Approaches for Complyıng with NEPA and SEPA}

The current NEPA documentation appears to adequately bound the range of impacts associated with the WFD system, so the recommended approach is to rely primarily on the existing NEPA record and on avallable CXs Existing NEPA documentation will be reviewed periodically in coordination with the tank farms Environmental Comphance Officer (ECO) as projects and activities are planned The adequacy of coverage by the existing NEPA documentation will, if necessary, be confirmed in writing with the DOE NEPA Compliance Officer If the scope of a particular project or activity is not suitably covered in existing NEPA documents it may be necessary to prepare an EA The expected outcome of the EA would be either a finding of no significant impact or the need to prepare an SA No circumstances are anticipated at this time that would lead to having to prepare an EIS or supplemental EIS All final decisions for actions to satisfy NEPA will require direction and approval by the DOE NEPA Compliance Officer

The recommended approach for SEPA compliance is to contınue relying on the avallable NEPA documentation Under this approach, the DOE NEPA Compliance Officer will forward copies of NEPA documentation to the state or local lead agency as needed to facilitate review and decision making Occasionally, depending on the scope and complexity of a particular project or activity it may be necessary to prepare a SEPA checklist and provide a crosswalk to 
HNF 2401

Revision 1

correlate where SEPA concerns have been addressed in the NEPA record SEPA compliance will be reviewed periodically in coordination with the tank farms ECO All final decisions for actions to satisfy SEPA will require direction and approval by the DOE NEPA Compliance Officer

\section{Significant NEPA/SEPA Issues}

No sıgnificant issues have been identıfied that require resolution at this tıme

\section{CULTURAL RESOURCES AND ECOLOGICAL COMPLIANCE REVIEWS}

A Cultural Resources Review is needed for any project involving excavation, demolition, modification, or deactıvation near or at a faclity or structure with potential historic, archaeological, or other cultural significance This may include any artifacts which have importance for Native American preservation, materials that have interpretive or educational value as exhibits withın local, state, or national museums, or any facility with the potential for inclusion on the National Register of Historic Places

An Ecological Compliance Review is needed if planned actıvitıes could disturb plant or animal species or their habitats This includes species that are or may be threatened, endangered, candidate sensitive, or are otherwise protected under state and federal laws and regulations This also includes taking, possession, transportation, sale, purchase/barter, export, or import of special status plants and animals (both living and dead)

The areas where projects and activities for the WFD system will occur are broadly included in the scope of two 'blanket reviews prepared (and periodically updated) for the RPP The Cultural Resources Review has been generally addressed in the Pacific Northwest Laboratory Cultural Resources Exemption of the Tank Farm Areas (Crist 1994) The Ecological Compliance Review has been generally addressed in the Pacific Northwest National Laboratory Blanket Blologlcal Review for the Tank Farm Facllties 200 E and $200 \mathrm{~W}$ Areas (Brandt 1999)

\section{Alternatives for Satısfying Applicable Cultural/Ecological Requirements}

Alternatıves to be considered for assuring cultural and ecological review compliance include the following

- Perform independent reviews for a proposed action

- Rely on the blanket reviews, with supplemental updates as necessary for work activities that are expected to occur outside the current review boundaries 
HNF-2401

Revision 1

\section{Recommended Approaches for Complyıng with Cultural/Ecological Requirements}

The recommended approach is to rely primarily on the blanket reviews The adequacy of the blanket review coverage will be reviewed periodically in coordination with the tank farms ECO as projects and activities are planned Supplemental information would be developed as necessary to update the blanket reviews

\section{Significant Cultural/Ecological Issues}

No significant issues have been identıfied that require resolution at this time

\section{PRE-OPERATIONAL MONITORING OF FACILITIES, SITES, AND OPERATIONS}

An evaluation of baseline environmental conditions (pre-operational monitoring) must be conducted before startup of a site facility, or process that has the potential for significant adverse environmental impact or for emissions of hazardous materials or radioactive substances The basic monitoring required includes radionuclide concentrations in the ambient air, background radiation levels at the project site and in surrounding areas, and radionuclides present in flora, fauna soll wildlife, and water Baselıne levels of hazardous chemicals present in the environment may also be of interest Pre-operational monitoring should begin not less than one year (preferably two years) before startup, so seasonal changes can be evaluated This information can be used for comparative purposes during periodic, near-facility monitoring to determine if the environment is being affected by facility operations and emissions

A substantial amount of information is avallable regarding environmental conditions and operational monitoring in and near the tank farms This information is relevant to the WFD system and is provided in various documents including but not limited to the following

- Environmental Monttoring Plan - Untted States Department of Energy Richland Operations Office (DOE 1997b)

- Factlty Effluent Monttoring Plan for the Tank Farms Facilttes (Crummel et al 1999)

- Environmental Releases for Calendar Year 1997 (Gleckler 1998)

- Hanford Site Near-Facility Environmental Monitoring Annual Report Calendar Year 1997 (Perkıns et al 1998)

- Hanford Stte Environmental Report for Calendar Year 1998 (Dirkes et al 1999) 
HNF-2401

Revision 1

\section{Alternatives for Performing Pre-Operational Monitoring}

Alternatives to be considered for the WFD system include the following

- Gather the required information specifically for WFD system projects and activities, relying on current routıne monitoring to a limited extent

- Use information gathered by routine Hanford Site and tank farms monitoring supplemented by data gathered for specific WFD supportıng projects and activities as necessary (e $\mathrm{g}$, for work in areas where baselıne monitoring and conditions are not well established)

\section{Recommended Approach for Pre-Operational Monitoring}

The recommended approach is to make maximum use of ongoing, routıne monitoring activities, and to identify the instances where current monitoring programs do not provide adequate coverage for work associated with the WFD system If current pre-operational information is not adequate, a supplemental monitoring program should be developed and implemented The tank farms ECO should be involved in determining adequacy of existing monitoring information and development and implementation (If necessary) of additional preoperational monitoring programs New environmental and emissions information will need to be integrated with data collection and reporting under other Hanford Site programs

\section{Significant Pre-Operational Monitoring Issues}

No significant issues have been identıfied that require resolution at this time

\section{EXCAVATION PERMIT}

An excavation permit is required before initiating any potential surface-disturbing onsite activities The review and approval process will consider proposed locations for all underground piping, pits pads and support structures, and should evaluate for possible intrusion into radiation control areas, underground contamination areas and buried tanks to avord unanticipated exposures The excavation permit also provides a final checkpoint for the ECO to ensure that the required cultural ecological, pre-operational monitoring, permittıng, and other environmental compliance actions have been adequately completed Detalled information needed for excavation permits are the responsibility of each project or activity performing organization The excavation permit must be approved by the tank farms ECO There are no alternatives to be considered for this approval requirement No significant issues have been identified that require resolution at this time 
HNF-2401

Revision 1

\section{DOE ACQUISITION/ENVIRONMENT, SAFETY AND HEALTH MANAGEMENT}

As a condition of DOE acquisition regulations, RPP contractors must ensure that actions are integrated through the site-wide Integrated Environment, Safety and Health Management System (ISMS) Each project and activity that supports the WFD system must ensure that ISMS is implemented in their work The tank farms ECO will ensure that applicable environmental requirements are identified and implemented for the WFD system, consistent with the requirements and objectives of the ISMS There are no alternatives that warrant consideration for this requirement No significant issues have been identified that require resolution at this time 
HNF-2401

Revision 1

This page intentıonally left blank 
HNF-2401

Revision 1

\section{AIR EMISSIONS}

The purposes of the federal Clean Air Act (CAA) and the Washington State Clean Atr Act (WCAA) are to protect public health and welfare by safeguarding air quality, establishing clean air standards, bringing non-attainment areas into compliance and protecting clean air from degradation The CAA and WCAA provide the authority for monitoring and controlling emissions of radioactive and non-radioactive constituents to the air In Washington State, air quality standards are implemented by the U S Environmental Protection Agency (EPA), Ecology, Washington State Department of Health (WDOH), and local arr authorities

\section{HANFORD SITE AIR OPERATING PERMIT}

State regulations establish a comprehensive Washington State Air Operating Permit (AOP) program that meets federal requirements and has been approved by EPA A single sitewide permit, the Hanford AOP, is required for the Hanford Site and will cover both radioactive and non radioactive alrborne emissions from significant emission units An emissions release source is considered significant if it has the potential to contribute more than one percent of the total Hanford Site's exposure to the general public The Hanford AOP is nearing final approval, and procedures for maintainıng and updatıng the Hanford $\mathrm{AOP}$ are under development Signatories to the Hanford AOP will include DOE, Ecology, WDOH, and the Benton Clean Air Authority Once approved, the Hanford AOP is expected to cover much of the work associated with the WFD system, including construction of new air emission sources, modification of existing air emission sources, or changes in operating practices for permitted sources

\section{Alternatives for Satısfying Hanford Air Operatıng Permit Conditions}

A number of uncertanties must be resolved about how the Hanford AOP will be implemented before compliance alternatıves can be fully identified Pending this resolution, the following general alternatives can be expected for WFD system projects and activities

- No change to the Hanford AOP will be necessary for a project/activity to proceed

- The Hanford AOP must be modified but the project/actıvity can proceed while the permit is being modified to incorporate the WFD system changes

- The project/activity cannot proceed untıl the Hanford AOP has been modified and reissued to incorporate the WFD system changes

If a project/activity cannot be accomplished in accordance with existing AOP conditions

(for example it is a new source of air emissions, or has the potential to increase emissions unless new treatment methods are applied), agency approval will likely be required It is not known whether this approval can be provided without first modifying the Hanford AOP (e g, in a letter) or whether permit modification will be necessary before agency approval 
HNF-2401

Revision 1

\section{Recommended Approach for Hanford Aır Operatıng Permit Compliance}

No approach can be recommended until after the final Hanford AOP is approved, and some of the uncertainties about its implementation have been evaluated with the permitting agencies In the meantime project/activity representatives should coordinate with the facility ECO durıng initial planning stages to evaluate potential compliance requirements under the Hanford AOP

\section{Significant Hanford AOP Issues}

Currently the most significant issues related to the Hanford AOP are understanding what procedures will be followed for incorporating new (or significantly modified) sources into the permit, and, determining what conditions (both interım and final) will be applied as the WFD system is modified Resolution of these issues will need to be coordinated through DOE because they have the potential to affect all Hanford Site air emission sources The regulatory agencies may not address these issues untıl after the Hanford AOP has been issued and some experience has been developed in implementıng it

\section{RADIOACTIVE AIR EMISSIONS}

Any new stationary source of radionuclide emissions is subject to a preconstruction review and approval by the EPA for compliance with the National Emission Standards for Hazardous Air Pollutants (NESHAPs) Also any new physical or operational activity that will provide any increase in potential emissions of radionuclides is defined as a modification and may require approval Approval is obtained by submitting a Notice of Construction (NOC) to EPA for approval to construct or modify The WFD system involves facilities and operations that emit or have the potential to emit, radionuclides to the air It is expected that most projects and activities will need to evaluate their work scope for NESHAPs applicability, and in many cases will have to support an NOC submittal and approval effort

In addition to EPA, WDOH regulates radioactive air emissions in Washington State under authority delegated by the Nuclear Regulatory Commission Any new activity (including any new construction work), process, or equipment that will involve potential emissions of radionuclides to the air is subject to a pre-construction review and approval which is initiated by submittal of an NOC to WDOH The WDOH requires the use of best available radionuclide control technology for all significant modifications or the use of as-low-as-reasonably-achievable control technology (ALARACT) for all nonsignificant modifications The WFD system involves facilities and components that emit, or may emit, radionuchdes to the air It is expected that many projects and activities will need to evaluate their work scope for possible WDOH approval and will have to support an NOC review process 
HNF-2401

Revision 1

Numerous NOC approvals have been 1ssued to tank farms, and these approvals are documented in Dexter (1999) Some "routıne" operations or maintenance may qualify for predefined control and monitoring practices set forth in Control of Airborne Radioactive Emissions for Frequently Performed TWRS Work Acttvittes (ALARACT Demonstrations) (Clark 1999) which WDOH has accepted in heu of a full NOC review process EPA does not require federal NOC approval for maintenance, repair, or replacement-1n-kınd activities that are deemed to be routıne for a source category To date EPA has indicated that they consider the activities covered by the ALARACT demonstrations (Clark 1999) to be routine

\section{Alternatıves for Satısfyıng Radıactıve Aır Emıssions Standards}

A variety of alternatıves may be avallable for ensuring the WFD system satısfies applicable radioactive arr emission standards but some are expected to be more viable than others Acceptability to agency reviewers, refinement of the final WFD system configuration, extent of knowledge and quantitative data, and effects of other actions in the tank farms and at the Hanford Site will influence whether and when a particular alternative would be appropriate Alternatives that warrant consideration include the following

- Develop a "programmatıc" NOC application for the entire scope of WFD system projects and activities and seek agency approval for all current and known future construction and operations With enough certainty and stability in the design and operation of the WFD system, it might be possible to provide the detarls and assurances needed for the agencies to accept this alternative

- Develop a "replicate' NOC application and seek agency approval for each type of WFD system work that has a well defined scope has common functions and features and will occur multiple times during the retrieval and delivery life-cycle Work examples that might be candidates for this alternative include installing mixer or transfer pumps constructing and tying-in new valve pits replacing cover blocks, and operatıng caustic addition and dilution systems Separate project and activityspecific NOC approvals would be sought for first of-kind or unique WFD system work Although not excluded by the regulations, the concept of a "replicate" NOC approval would probably be unfamiliar to (and initially resisted by) the agencies

- Develop "project" NOC applications and seek agency approvals for each major WFD system construction project (e g W-211, W-521) Separate NOC approvals would be sought for WFD system work that was not included within the scope of an approved project Modifications to NOC approvals would be requested if the approved work scope changes or becomes better defined This approach might also be applicable to project-like work, similar activities that involve a substantial level of effort and support a common purpose (e $\mathrm{g}$, inspection and maintenance of pit and cover coatıngs, repair and maintenance of in-tank or pit monitoring equipment) 
HNF-2401

Revision 1

- Develop "geographı" NOC applıcations and seek agency approvals for all work occurring within a common physical location (e $\mathrm{g}$, in a tank farm, along a transfer route) This approach may not be supported by the regulations which tend to emphasize air emission units and the projects that construct or modify them

- Work with the agencies to expand the scope and applicability of the ALARACT demonstrations (Clark 1999) to cover some or all of the current and known future WFD system construction and operations This alternative would depend on the willingness of the agencies to change a previously expressed position that projects are significant modifications and cannot be considered routıne

- Work with the agencies to expand the ALARACT demonstrations (Clark 1999) to cover WFD system retrieval and delivery activities that are regular and repetitive (e g mixer pump operation, feed transfers to BNFL Inc ) Separate NOC approvals would be sought for WFD system work that involves construction and physical modifications, and other work actıvities that are not regular or routıne

- Develop "action-spectfic" NOCs and seek agency approvals for each discrete work package This alternative would result in narrow, work-specific NOC approval conditions that could be applied relatively easily to each separate WFD system action However, this alternative may constitute project segmentation, which is generally disallowed under the applicable arr regulations In addition, the number of NOC approvals (and associated conditions) to be negotiated, tracked, maintained, and implemented would be significantly more than the other alternatives

\section{Recommended Approach for Radioactive Air Emıssions Compliance}

The recommended approach is to pursue two paths in parallel, one to ensure ongoing compliance in the near-term, the other to promote overall consistency and simplify long-term compliance efforts

- The "project NOC alternative should be used for now because it has the least potential for near term schedule impacts The agencies have expressed their preference for and familiarity with this approach for major projects and activities, and tank farms environmental personnel have developed a base of experience with this approach Problems with this approach include the need for updates to NOC approvals when changes (even minor ones) occur to the project scope, tendency of the agencies to revisit and expand approval conditions even though similar activities have been approved in earlier projects, and, difficulty anticipating and approving future operations that are enabled by the project

- For future purposes, the agencies should be asked to consider other alternatives that would be more efficient and would streamline NOC approvals for the WFD system The "replicate" NOC approach has several advantages for conductıng project and construction work, including the ability to develop and reuse standardized conditions 
for limiting and controlling emissions during in-field work The ALARACT demonstrations (Clark 1999) coverage could be expanded to address many of the expected WFD system operatıng activities as the scopes of these activities become more refined The agencies would rely on action-specific' NOC approvals when needed to address unique events or new construction projects that have not been previously reviewed

Regardless of which approach is pursued radioactive air emissions monitoring and control technology will need to be addressed by WFD system projects and activities and will require agency approval Project/actıvity representatives should coordinate with the facility ECO during initial planning stages to evaluate potential approval and compliance requirements

\section{Signıficant Radioactıve Aır Emıssions Issues}

Key issues associated with radioactive arr emissions include the following

- It is not clear how completely a project (e g, W 211) must anticipate and include in its NOC application the range of future operations that will be able to occur as a result of the project's work For example, if a project installs a mixer pump, what bounding conditions should be used to estimate potential radioactive air emissions that will occur when the mixer pump is operated? It will probably be necessary to make assumptions that may or may not be correct when operations begin, what is an acceptable range of variance from the original assumptions before the NOC approval would need to be revised and reissued by the agency?

- It is not known whether the proposed long-term approaches for streamlining the NOC process will be acceptable to the regulatory agencies There has been hittle evidence to date that the agencies can be flexible in considering potential alternatives

- The applicability of the ALARCT demonstrations (Clark 1999) may not be as broadly interpreted by $\mathrm{WDOH}$ as had been previously thought Activities that tank farms personnel would consider to be routıne (e $\mathrm{g}$, transfers, mixing chemical adjustments to improve transfer characteristics) may not qualify under WDOH's interpretations This difference will need to be clarified to determine how future WFD system operations must satısfy the NOC process

\section{NON-RADIOACTIVE AIR EMISSIONS}

Ecology implements a program for prevention of significant deterioration (PSD) to existing air quality from emıssions of criteria pollutants (e $g$, particulates, carbon monoxide, nitrogen oxides) Pre-construction approval could be required by Ecology, which would be initiated by submittal of an NOC application Project and activity representatives should coordinate with the facility ECO during initial planning stages to ensure WFD system compliance with the PSD requirements and to coordinate the PSD determination with the new 
HNF-2401

Revision 1

source review (NSR) process (see following discussion) A PSD permit will probably not be required for most, if not all WFD system work but this will need to be confirmed and documented for projects and actıvitıes as they are defined

Any new activity, project, process, or equipment that will involve potential emissions of contamination to the air is also potentially subject to a NSR and pre-construction approval by Ecology Information about the new or modified source is submitted to Ecology in an NOC, which must include an assessment of best avallable control technology to be used Constructing and operating the WFD system is expected to modify existing sources of air emissions, and to add new sources that do not currently exist, so many projects and activities may be subject to the NSR requirements Project/activity representatives should coordinate with the facility ECO during initial planning stages to determine if an NSR and Ecology approval will be required for their scope of work Final determination would be documented either through an NOC submittal (If NSR and approval are necessary), or else by letter to file (including possible confirmatory correspondence with Ecology) indicating an NSR and approval are not required

Any new or modified sources of air emissions must be assessed for possible emissions of toxic air pollutants (TAPs) If emissions exceed certain thresholds, dispersion modeling must be performed to determine if the offsite concentration for each constituent could exceed regulatory limits In most cases, the TAPs regulations require the use of best avallable control technology for toxics (T-BACT) Current information about the tank farms indicates a potential for the DST primary ventilation systems to emit TAPs (e g, organics, ammonia), but it is not known whether regulatory limits could be exceeded Only the combined ventilation system for the AY and AZ tank farms has TAPs emission controls and an NOC approval from Ecology Studies are planned to predict possıble TAPs emıssıon rates and to determine what, if any, upgrades should be made to the DST ventilation systems to control TAPs Pending completion of these studies, project and activity representatives will need to work with the facility ECO to determine whether or not their particular scope of work is likely to require an NOC submittal and approval for TAPs air emissions

\section{Alternatıves for Satısfyıng Non-Radioactıve Aır Emıssions Standards}

There are no unıque PSD compliance alternatıves, ensuring PSD consideration durıng the NSR is the only expected compliance action Potential alternatives for satisfying the NSR and TAPs requirements include

- Develop a single NOC to provide a complete NSR and TAPs assessment for the entire WFD system and seek a comprehensive approval With enough certainty and stability in the design and operation of the WFD system it might be possible to provide the detalls and assurances needed for Ecology to accept this alternative

- Develop NOCs to support the NSR and TAPs assessment for each tank farm or major work area Under this alternative, Ecology approval would be sought for work within common physical locations (e g in a tank farm, along a transfer route) Separate NOC approvals would be sought for unique or "out of area" WFD system work 
HNF-2401

Revision 1

- Develop NOCs to support the NSR and TAPs assessment for each WFD system major project and major actıvity (related/sımılar work that supports a common purpose) Separate NOC approvals or modifications would be requested if approved work scope changes or becomes better defined

- Develop NOCs to support the NSR and TAPs assessment for each discrete WFD system work package This alternative would result in narrow, work-specific NOC approval conditions that could be applied relatively easily to each separate WFD system action However, the number of NOC approvals and conditions would be significantly more than for the other alternatives

\section{Recommended Approach for Non-Radioactıve Alr Emıssions Compliance}

The recommended approach is to pursue two paths in parallel, as follows

- The recommended near-term approach is to seek NOC approvals for each major project and activity as they arise This approach is familiar to Ecology and tank farms environmental personnel have a relevant experience base The main difficulty of this approach is the need to update NOC approvals when changes occur to the scope of an approved project or activity

- For future purposes, the previously noted studies (to predict possible TAPs emission rates and determine any warranted upgrades to the DST ventilation systems) should proceed as expeditiously as possible When sufficient information has been developed it should be possible to ask Ecology to either concur that TAPs emissions will not require NOC approval or else to issue NOC approvals for each tank farm that may have TAPs exceedances It may be possible then to perform one or a limited number of NSRs for the remaining WFD system work

\section{Significant Non-Radioactive Air Emissions Issues}

The key significant issue is lack of sufficient data to estımate potential TAPs emissions Without the necessary data, WFD system projects and activities will have to either proceed at risk ( 1 e assume the regulations do not apply), or else plan to design and procure TAPs treatment and monitoring systems to meet standards that are not known to be applicable 
HNF-2401

Revision 1

This page intentionally left blank 


\section{WATER AND WASTE WATER MANAGEMENT}

Work associated with development and operation of the WFD system may directly or incidentally affect the Hanford Site potable water system Projects and activities may also result in the need to dispose of waste water from hydrotesting cooling, condensation, and/or stormwater collection Water quality protection requirements that are potentially applicable to the WFD system are summarized in this section

\section{DRINKING WATER SYSTEMS}

The Hanford Site drinkıng and fresh water supply systems are overseen by the Hanford Site Water Purveyor, who ensures that the systems are installed maintained, and operated in accordance with applicable WDOH regulations for drınkıng water systems The Water Purveyor must review and approve equipment, facilities and activities that connect to or could otherwise affect the drinkıng water system on the Hanford Site Modification of existing water supply systems to extend service is assumed to be within normal maintenance activity and should not require WDOH approval

The WFD system will rely on the existıng Hanford Site drinkıng water supply and major expansions (to an extent that could require WDOH approval) are not expected Projects and activities to support the WFD system will include tie-ins to fresh water supplies (e g , drinkıng water in new buildings, fire suppression, dilution and flush water), and will probably construct or use equipment near water supply systems (e g , excavation near water lines, installation of structures above water systems, waste transfer lines crossing over or under water lines) The Water Purveyor will need to review this work to ensure that connections and facilities are installed and operated in compliance with the WDOH standards and approved Hanford Site plans and specifications

Project/activity representatives should coordinate with the Water Purveyor and the facility ECO during initial planning stages to evaluate proposed work for consistency with the applicable water system requirements Early involvement of the Water Purveyor during facility design will be particularly important when tie-in to the water supply system is expected Water Purveyor review and approval would typically be obtained on a project specific basis as the need for tie-ıns or work locations near water lines are identıfied There are no alternatives to this approach that warrant consideration for the WFD system No significant drinking water system issues have been identified that require resolution at this time

\section{STATE WASTE DISCHARGE PERMIT}

A state waste discharge permit (SWDP) is required for any industrial commercial, or mumcipal operations that may discharge waste water in a manner that could pollute the groundwaters of Washington State Before construction or modification, waste water facilities requiring an SWDP permit must submit an application to Ecology, and must provide engineering 
reports, plans, and specifications for the project Ecology must approve the SWDP application and accompanying materials before construction begins Operation and maintenance manuals must be submitted before construction is completed Activities covered by an existing SWDP must comply with the conditions of the permit Effluent control systems typically include a combination of best management practıces (BMPs) to minimize effluent and pollutant generation, and use of all known, avallable, and reasonable treatment for effluent streams prior to discharge A monitoring system and plan is usually required, which may include effluent testing, vadose zone measurements, and/or groundwater sampling and analysis

Ecology has issued three "categorical" SWDPs for the Hanford Site that may affect projects and activities associated with the WFD system Each of these categorical SWDPs includes conditions on the rate and quantities of discharges, sources of water, BMPs that must be developed and implemented, and record keeping and reporting The three Hanford SWDPs cover the following

- Hydrotesting discharges, maintenance discharges (including drainage and flushing activities) and construction discharges (including concrete curing and pressure washing actıvities)

- Coolıng water (e g , air compressors, diesel engines, ventılation, evaporatıve coolıng), condensate, and other miscellaneous discharges (e g water tank overflows, quench tanks)

- Stormwater discharges to ground that are collected in engineered structures (e g, lined trenches, basıns, tanks, sumps, roofs, parkıng lots) and then discharged to engineered disposal structures (e $\mathrm{g}$, dry wells, catch basıns, infiltratıon trenches)

The conditions in the SWDPs are self-implementıng, and affected WFD system projects and activities should not require prior agency approval as long as permit conditions are met Project/activity representatıves should coordınate with the facility ECO during initial planning stages to determine whether their work scope may be subject to the categorical SWDPs and if so to evaluate potential compliance requirements and permit conditions that must be satisfied in the facility design and operation Compliance with the SWDPs will typically be established on a project-specific basis as applicability to the expected work scope is identıfied There are no alternatives to this approach that warrant consideration for the WFD system No significant SWDP issues have been identified that require resolution at this time 
HNF-2401

Revision 1

\section{RADIOACTIVE MATERIALS AND WASTE MANAGEMENT}

DOE orders provide standards and guidelines for limiting public and environmental exposures to radionuclides, and require a written environmental monitoring plan (EMP) for each site, facility, or process that uses, generates, releases, or manages significant pollutants or hazardous materials The effluent monitoring portion of each EMP must verify compliance with applicable regulations and DOE Orders An EMP has been prepared for all DOE activities on the Hanford Site and is updated every 3 years to include new or modified facilities and projects (DOE, 1997b) Effluent monitoring is documented for each major facility on the Hanford Site through a specific facility effluent monitoring plan (FEMP)

A FEMP specific to tank farm facilities exists, and describes the monitoring expectations for air and liquid effluents (Crummel et al 1999) The requirements of this FEMP are expected to be relevant to the WFD system, and project/actıvity representatıves should coordinate with the facility ECO during initial planning stages to evaluate potential compliance requirements There are no radioactive materials and waste management alternatives that warrant consideration for the WFD system No significant issues have been identıfied that require resolution at this time 
HNF-2401

Revision 1

This page intentionally left blank 
HNF-2401

Revision 1

\section{SOLID AND DANGEROUS WASTE MANAGEMENT}

A comprehensive national program, implemented by EPA, has been established pursuant to the federal Resource Conservation and Recovery Act of 1976 (RCRA) to ensure that hazardous waste management will not threaten human health and the environment The Washington State Hazardous Waste Management Act (HWMA) authorized Ecology to conduct an equivalent state program Although the state program operates in lieu of, and in some cases exceeds, the federal requirements, dual jurisdiction by EPA and Ecology continues for a few provisions (e $\mathrm{g}$, land disposal restrictions, corrective action) Differences are noted below if they are significant to the WFD system (Note that in the rest of this section the Washington State regulatory term "dangerous waste" is used rather than hazardous waste )

\section{WASTE OILS}

Waste oll may be subject to special management standards if it is dangerous and disposed of or recycled without proper care Generators of waste oil must be able to show that their oll was delivered to an approved recycler or disposed of properly Most of the other waste orl requirements only affect marketers or burners of the waste o1l Waste olls may be generated during routine maintenance of vehicles construction equipment, hydraulic devices, and other machinery used to buld and operate the WFD system Projects and activities will need to ensure that waste orls generated within their scope of work are collected and dispositioned in accordance with the Hanford Site-wide used ol management program There are no alternatives to this approach that warrant consideration for the WFD system No significant waste oll issues have been identified that require resolution at this time

\section{DANGEROUS WASTE TREATMENT, STORAGE, AND DISPOSAL FACILITIES}

\section{Interım and Final Status Standards}

Implementing regulations promulgated pursuant to RCRA and HWMA require dangerous waste treatment, storage, and disposal (TSD) facilities to comply with numerous design and operating requirements and to obtain a permit Facilities in existence when the regulations were adopted were allowed to qualıfy for and contınue operatıng under interım status Eventually, all dangerous waste TSD facilities must either close or receive a final status permit The DST system is currently operatıng under interım status, with a calendar year 2000/2001 timeframe for final status permittıng The SST system is currently operating and is expected to be closed under interım status

Most, if not all, of the WFD system must currently comply with interim status standards Most of the Privatization Phase 1 WFD system is expected to be included within the DST 
HNF 2401

Revision 1

system final status permit and will be required to comply with the final status standards Some portions of the WFD system may be within the SST system, and current understanding of the Hanford Federal Facility Agreement and Consent Order (Ecology et al 1996), also referred to as the Tr1-Party Agreement, is that the SST elements of the WFD system will not have to comply with the final status standards In addition non-compliant components of the SST system may not have to comply with the interim status standards unless they are replaced or modified

\section{Recommended Approach for Dangerous Waste Treatment, Storage, and Disposal Facility Compliance}

During interim status, facility and operational changes can be accomplished with little or no involvement by a regulatory agency as long as applicable interım status standards are satisfied Once a final status permit is issued, however significant changes to the DST system may not be implemented without prior agency concurrence and permit modification Conditions for obtaining agency approval of facility modifications will not be known until the final status permit negotiations are complete In addition, it is not known at this time what types of SST system changes could be significant enough to warrant regulatory agency involvement, this will also be a matter for future negotiations Therefore, there currently are no reliable dangerous waste alternatives for the WFD system that can be reasonably considered

Untıl agency negotiatıons are complete, DST system projects and actıvities will be expected to satisfy the dangerous waste interım status requirements, and to seek consistency and compatibility of future work scope with the final status standards (where differences with interim status requirements exist) Projects and activities that modify the SST system will also be expected to achieve interım status requirements for new and upgraded facility components Project/actıvity representatives should coordinate with the facility ECO durıng initial planning stages to evaluate whether interım or final status standards apply and to determine the applicable compliance requirements

\section{Signıficant Dangerous Waste Treatment, Storage, and Dısposal Facility Issues}

During preparation of the final status permit application for the DST system, it may not be possible to provide information for the planned WFD system at the level of detall required by Ecology If all of the WFD system work is not sufficiently described in the final status permit when issued then the permit may need to be modified before new, "unapproved" work can proceed This poses a risk of construction and operation delays while agency negotiations and public review are conducted It would be preferable if the final status permit could be negotrated and written to approve the overall scope of WFD system work, and to allow at least initial procurement and construction for particular upgrades to begin while the permit is being modified 
HNF-2401

Revision 1

\section{MISCELLANEOUS REQUIREMENTS FOR DANGEROUS WASTE MANAGEMENT}

Other parts of the dangerous waste regulations require submittal of various notifications, certifications and/or approval requests to Ecology Requirements that may be significant for the WFD system include the following

- Some WFD system definition and design decisions may depend on performance of laboratory tests for physical properties and chemical/radiological makeup of tank farm waste samples It is not known whether any of these tests will meet the "treatability study" definition in the regulations If so, the performing laboratory will need to notify Ecology and maintain test and waste sample handling records

- Required land disposal restriction notifications will need to be made at some future tıme when waste feed delivery to BNFL Inc begins The type and level of detail of information to be included in these notices have not been determined yet

- It is possible that unanticipated contamination of the environment may be encountered during work in the tank farms, although this is not expected for the work scope of the current projects and activities that support the WFD system If the contamination involves releases of dangerous waste constituents, the unplanned release notıfications and corrective action requirements could apply

The relevance and applicability of these miscellaneous dangerous waste requirements for the WFD system will depend on project and activity-specific circumstances Project/activity representatives should coordinate with the facility ECO during initial planning stages to evaluate whether any of these miscellaneous dangerous waste standards may apply, and to determine applicable compliance requirements There are no alternatives that warrant consideration for the WFD system No significant issues for these miscellaneous requirements have been identified that must be resolved at this time 
HNF-2401

Revision 1

This page intentionally left blank 
HNF-2401

Revision 1

\section{HAZARDOUS SUBSTANCES}

Work associated with the development and operation of the WFD system is expected to handle or encounter a wide range of non-radioactive hazardous substances that are subject to federal and state regulations In general, site-wide procedures already exist and are implemented as needed by projects and activities conducted on the Hanford Site The hazardous substance programs that are potentially applicable to the WFD system are summarized in this section

\section{OZONE DEPLETING SUBSTANCES}

EPA regulates the use of ozone depleting substances such as chlorofluorocarbons These compounds are to be recovered and recycled to the maximum extent practical, and their eventual use is to be phased out Ancillary systems (e g, chillers, air conditioners) that support tank farm operations may be using ozone depleting substances, and projects or activities that affect these systems may be required to satısfy the applicable regulations Project/activity representatives should coordinate with the facility ECO during initial planning stages to determine potential compliance requirements There are no alternatives to this approach that warrant consideration for the WFD system No significant issues relative to this environmental requirement have been 1dentified for the WFD system

\section{ASBESTOS}

Asbestos is a controlled respiratory carcınogen and all work involving asbestos containing materials must be done by trained and certified personnel Any proposed reconstruction repair, or demolition involving asbestos must be reviewed for possible pre-project notification to the Benton Clean Air Authority The WFD system is not expected to use or install equipment or materials that contain asbestos, but it is possible that equipment or items (e $\mathrm{g}$, gaskets, pipe insulation) removed during upgrades to the WFD system could contain asbestos Project/activity representatives should coordinate with the facility ECO during initial plannıng stages to determine if asbestos notification, and/or use of certified asbestos removal personnel, may be required There are no alternatives to this approach that warrant consideration for the WFD system No significant issues relative to this environmental requirement have been identified for the WFD system

\section{POLLUTION PREVENTION, WASTE MINIMIZATION, COMMUNITY RIGHT-TO-KNOW NOTIFICATION AND REPORTING}

Various federal and state standards require implementation of pollution prevention and waste minımization practices All Hanford facilities are covered by the Hanford Site Waste Minımization and Pollution Prevention Plan New facilities must develop a Pollution Prevention/Waste Minimization strategy and incorporate relevant guidelines into any operatıons 
prior to startup Plan and report information are submitted to Ecology and other agencies as required

Regulations adopted pursuant to the federal Emergency Planning and Community Rightto Know Act (EPCRA) require that information about the types, locations, and hazards of specified substances be provided to state and local emergency response authorities EPCRA also requires that annual reports be submitted to EPA to document releases to the environment of chemicals used in excess of established threshold quantities State and local notices and annual reportıng are coordinated through a single office for the entire Hanford Site

Pollution prevention waste minımization, and EPCRA requirements are implemented through various tank farm and Hanford Site-wide procedures Projects and activities that support the WFD system will be expected to satısfy the applicable planning and reportıng requirements for their scope of work Project/activity representatives should coordınate with the facility ECO during initial planning stages to determine potential compliance requirements and to ensure that applicable notification and reporting instructions are included in field work orders and procedures, as necessary There are no alternatıves to the existing Hanford Site programs that warrant consideration for the WFD system No significant issues relative to these environmental requirements have been identified for the WFD system

\section{NOTIFICATION AND REMEDIATION OF ENVIRONMENTAL RELEASES}

Unpermitted environmental releases of petroleum products and hazardous substances are subject to notification and remediation requirements under the federal Comprehensive Environmental Response Compensation and Liability Act (CERCLA) and the Washington State Model Toxics Control Act (MTCA) Notification is required if a release exceeds a reportable quantity (or other regulatory threshold) for the released compound Remedration may be required if EPA or Ecology determine the release poses a threat to human health or the environment and cleanup is not adequately addressed under some other regulatory program (e g , RCRA)

Environmental releases encountered within the tank farm boundaries would most likely be subject to notification and corrective action standards under the dangerous waste regulations It is possible that spills of petroleum products or chemical reagents could occur during construction or operations in or near a tank farm (e g , gas tank rupture, chemical addition leak) It is also possible that construction work outside the tank farms could encounter contamination from past practices (e g, transfer line construction through an old waste disposal unit) For unanticipated spills and releases, Hanford Site notification and reporting procedures would be followed and coordinated through a central office Site emergency response procedures would be implemented to contain and remove spilled materials Site cleanup and remediation contractors would be involved in addressing past-practice releases and abandoned disposal sites that are not within, or extend outside of, tank farm boundaries

It is reasonable to expect that projects and activities associated with the WFD system could encounter circumstances under which the notification and remediation requirements of 
HNF-2401

Revision 1

CERCLA and MTCA will be applicable Project/activity representatives should coordinate with the facility ECO during initial planning stages to determıne potential compliance requirements and to ensure that applicable notification, reporting, and response instructions are addressed in field work orders and procedures, as necessary There are no environmental release alternatıves that warrant further consideration at this time for the WFD system No significant issues relative to this environmental requirement have been identıfied for the WFD system

\section{POLYCHLORINATED BIPHENYLS}

EPA regulates the use and disposal of polychlorinated biphenyls (PCBs), based on the original sources and concentrations of these compounds To date no circumstances have been identıfied to cause PCBs in current Hanford Site tank wastes to be regulated, but future agency negotiations, modified site operations or new information about the wastes could result in changes to the existing regulatory status Project/actıvity representatıves should periodically coordinate with the facility ECO to reconfirm the status of the PCB regulations At this time, there are no alternatives to this approach that warrant consideration for the WFD system There currently are no significant issues relative to this environmental requirement, but numerous significant issues will arise if it is determined that the PCB regulations apply to the Hanford Site tank wastes 
HNF-2401

Revision 1

This page intentionally left blank 
HNF 2401

Revision 1

\section{REFERENCES}

40 CFR 61, 1991, "Natıonal Emıssions Standards for Hazardous Air Pollutants (NESHAP)' Code of Federal Regulations, as amended

62 FR 8693 "Record of Decısıon for the Tank Waste Remedıatıon System," Federal Register, Vol 62

60 FR 61687, "Record of Decısıon for Safe Interım Storage of Hanford Tank Wastes' Federal Reglster, Vol 60

Boes K A, 1996, Conceptual Destgn Report for Tank Farm Restoration and Safe Operations Project W-314 WHC-SD W314 CDR-001, Rev 1, prepared by Numatec Hanford Corporation for Fluor Daniel Hanford, Inc, Richland, Washington

Brackenbury, P J , 1999a Project Definttion Criterla for Project $W-521$ Waste Feed Delivery Systems HNF-4408, Rev 0, prepared by Numatec Hanford Corporation for Fluor Daniel Hanford Inc, Richland Washington

Brackenbury P J , 1999b, Scope Analysis Report for Project W-521 Waste Feed Delivery Systems, HNF 4705 Rev 0, prepared by Numatec Hanford Corporation for Fluor Daniel Hanford Inc, Richland, Washington

Brandt, C A , 1999, Blanket Biological Review for the Tank Farm Facllties 200 E and $200 \mathrm{~W}$ Areas letter to Bradley G Erlandson, Lockheed Martın Hanford Corporation, \#99-200-044, (April 16), Pacific Northwest National Laboratory, Richland, Washington

Clark D E 1999, Control of Alrborne Radioactive Emissions for Frequently Performed TWRS Work Activities (ALARACT Demonstrations), HNF-4327, Rev 0, prepared by Fluor Daniel Hanford, Inc for the U S Department of Energy Richland, Washington

Comprehenstve Environmental Response Compensation and Liability Act of 1980, Public Law 96-510, 94 Stat 2767, 42 USC 9601, et seq

Crist M E, 1994 Cultural Resources Exemptton of the Tank Farm Areas letter to W B Bancroft, Westinghouse Hanford Company, , (August 16), Pacific Northwest Laboratory Richland, Washıngton

Crummel, G M, P C Miller, L P Diediker, and W R Thackaberry, 1999, Facility Effluent Monitoring Plan for the Tank Farms Factlities, HNF-EP-0479-3, prepared by Fluor Daniel Hanford, Inc , for the U S Department of Energy, Richland, Washington

Dexter, M L 1999, TWRS Environmental Permits and Related Documentation, HNF-4474 (latest update) prepared by Fluor Daniel Hanford Inc, for the U S Department of Energy, Richland, Washington 
HNF-2401

Revision 1

Dirkes, R L , R W Hanf and T M Poston, 1999, Hanford Site Environmental Report for Calendar Year 1998, PNNL-12088, prepared by Pacific Northwest Natıonal Laboratory, for the U S Department of Energy, Richland, Washington

DOE, 1995, Safe Interim Storage of Hanford s Tank Waste Final Environmental Impact Statement, DOE/EIS 0212, U S Department of Energy, Richland, Washıngton

DOE 1996 Tank Waste Remediatıon System Hanford Site Richland Washington Final Environmental Impact Statement, DOE/EIS-0189, U S Department of Energy and Washıngton State Department of Ecology, Ruchland, Washıngton

DOE 1997a Supplement Analysis for the Proposed Upgrades to the Tank Farm Ventllation Instrumentation and Electrical Systems Under Project W-314 in Support of Tank Farm Restoration and Safe Operations, DOE/EIS-0189 SA1, U S Department of Energy, Richland, Washington

DOE 1997b, Environmental Monttoring Plan Untted States Department of Energy Rtchland Operatıons Office, DOE/RL-91-50, Rev 2 U S Department of Energy, Richland Operations Office Richland, Washington

DOE, 1998a, Supplement Analysis for the Tank Waste Remediation System, DOE/EIS-0189-SA2, U S Department of Energy Richland, Washington

DOE 1998b, Hanford Stte Tank Waste Remediatıon System Programmatıc Environmental Review Report, DOE/RL 98-54, Rev 0, U S Department of Energy, Richland, Washington

Ecology, EPA, and DOE, 1996, Hanford Federal Facllty Agreement and Consent Order, Washington State Department of Ecology, U S Environmental Protection Agency, U S Department of Energy, Richland Operatıons Office, Olympıa, Washıngton, amended periodically

Ecology and DOE, 1999, Dangerous Waste Portion Of The Resource Conservation And Recovery Act Permit For The Treatment Storage And Disposal Of Dangerous Waste At The Hanford Factlity, Permit Number WA7890008967 (amended periodically), Washıngton State Department of Ecology, Olympıa, Washıngton, U S Department of Energy, Richland Operations Office, Rıchland, Washıngton

FDH, 1998, NEPA Source Gulde for the Hanford Site, HNF-SP-0903, Rev 5, prepared by Fluor Daniel Hanford, Inc , for the U S Department of Energy, Richland, Washington 
HNF-2401

Revision 1

Friberg, A H, J N Appel K C Burgard, R B Calmus, O R DoValle S E Seeman, J R Freeman-Pollard, and A B Carlson, 1999, Rtver Protection Project Tank Waste Retrleval and Disposal Mission Technical Baseline Summary Description, HNF-1901, Rev 1, prepared by Lockheed Martın Hanford Corporation for Fluor Daniel Hanford, Inc , Richland, Washington

Gilbert J L , 1998, Tank Farm Restoration and Safe Operation Project W-314 Upgrade Scope Summary Report (USSR), HNF SD-W314-RPT-003 Rev 3, prepared by Numatec Hanford Corporation for Fluor Daniel Hanford, Inc , Richland, Washington

Gleckler B P, 1998, Environmental Releases for Calendar Year 1997, HNF-EP-0527-7, prepared by Fluor Daniel Hanford, Inc, for the U S Department of Energy, Richland, Washington

Kırkbride, R A G K Allen, R M Orme, R S Wittman J H Baldwin, T W Crawford, J Jo, L J Fergestrom, T M Hohl and D L Penwell, 1999, Tank Waste Remediation System Operatıon and Uttlization Plan to Support Waste Feed Dellvery, HNF-SD-WM-SP-012, Rev 1 Numatec Hanford Corporation Richland, Washington

Natıonal Environmental Policy Act of 1969, 42 USC 4321, et seq

NEPA Site-Wide Categorical Exclustons, http //www rl gov/wastemgt/nepa/swcx/swcx html website maintained for the Hanford Site by Waste Management Federal Services of Hanford, Inc, Richland, Washington

ORP, 1999, Tank Waste Operatıons, Contract DE-AC06-99RL14047, U S Department of Energy, Office of River Protection, Richland, Washington

Papp, I G, K S Tollefson, R D Potter R L Treat 1998 Project W-314 Phase I Environmental Permits and Approvals Plan HNF-3054, Rev 0 prepared by Lockheed Martın Hanford Corporation for Fluor Daniel Hanford Inc Richland, Washington

Perkıns C J A R Johnson, B M Markes, S M McKınney, R M Mitchell, 1998, Hanford Site Near-Faciltty Environmental Monitoring Annual Report Calendar Year 1997, HNF-EP-0573-6, prepared by Fluor Daniel Hanford, Inc, for the U S Department of Energy, Richland Washington

Rasmussen, O R 1998 Waste Feed Delivery Technical Basis Volume III Waste Feed Dellvery System Description, HNF-1939 Vol III Rev 0, prepared by Lockheed Martın Hanford Corporation for Fluor Daniel Hanford, Inc , Richland, Washıngton

Resource Conservation and Recovery Act of 1976, as amended, 42 USC 6901, et seq

Rieck C A, 1997, Functıonal Design Criteria Project W-211 Inttal Tank Retrieval Systems, HNF-SD-W211-FDC-001, Rev 3, prepared by Numatec Hanford Corporation for Fluor Daniel Hanford, Inc , Richland Washington 
HNF-2401

Revision 1

Rieck, C A , 1998, Interface Document Project W-211 Inttal Tank Retrieval Systems, HNF-1507, Rev 0, prepared by Numatec Hanford Corporation for Fluor Daniel Hanford, Inc , Richland Washington

RL, 1996, Hanford Strategıc Plan, DOE/RL 96 92, U S Department of Energy, Richland Operations Office, Richland, Washington

RL, 1998 TWRS Privatization, Contract DE-AC06-RL13308, as modified, U S Department of Energy, Richland Operations Office, Richland, Washıngton

Tollefson, K S , 1999, Project W 521 Waste Feed Delivery Systems Environmental Permits and Approvals Plan, HNF-4270, Rev 0 prepared by Lockheed Martın Hanford Corporation for Fluor Daniel Hanford, Inc Richland, Washıngton

Washington State Environmental Policy Act, as amended, Chapter 43 21C RCW 
Revision 1

\section{APPENDIX A}

\section{ENVIRONMENTAL PERMITS, APPROVALS AND REQUIREMENTS CHECKLIST AND NARRATIVE FOR THE WASTE FEED DELIVERY SYSTEM}


HNF-2401

Revision 1

This page intentionally left blank 
HNF-2401

Revision 1

\section{APPENDIX A}

\section{ENVIRONMENTAL PERMITS, APPROVALS, AND REQUIREMENTS CHECKLIST AND NARRATIVE FOR THE WASTE FEED DELIVERY SYSTEM}

\section{INTRODUCTION}

The Environmental Permits, Approvals, and Requirements (EReqs) Checklist is a general purpose tool for identifyıng environmental standards and determınıng their applicability to Hanford Site work The EReqs Checklist is updated as necessary to account for new or changed federal and state regulations, significant permit and approval conditions, and other relevant environmental mandates Table A-1 of this appendix presents a completed EReqs Checklist, showing the results of the environmental applicability determinations for projects and activities that support the waste feed delivery (WFD) system The last column of Table A-1 indicates whether an environmental permit approval or requirement was found to be potentially applicable to WFD system work

Following the EReqs Checklist is the EReqs Narrative, which provides additional background information for the various environmental programs For each permit, approval or requirement that was determined to potentially apply to the WFD system, the EReqs Narratıve explains the rationale for the applicability determınation, in some cases, a "not applicable' determination may also warrant explanation in the EReqs Narrative The following key contacts have expertise in the respective environmental programs and can offer additional information about the items in the narrative discussion

- K S Tollefson-River Protection Project (RPP) Environmental Services, Technical Contact for WFD System

- P C Miller - RPP Environmental Services, Tank Farms Environmental Compliance Officer (ECO)

- R D Potter - WFD System Definition, Technical Contact for Environmental Issues

The scope of WFD system work covered by this EReqs applicability determination is summarized in Section 10 of this document The full extent of the WFD system is still being defined, many of the supporting projects and activities will undergo further refinement as they proceed to final design, and environmental mandates can change over time Thus, the EReqs Checklist and Narratıve provide a "temporary" applicability determination that must be updated periodically In addition, a potentially applicable permit or requirement may only be relevant for particular types of projects or activities, and not to all work supporting the WFD system Each major project and activity will need to apply the information and rationales developed in this appendix to their current status and circumstances It is expected that this will result in projector actıvity-specific permittıng and compliance strategies that will allow managers to adequately incorporate environmental actions into their work scope, schedule, and resource planning 
Table A-1 Environmental Permits, Approvals, and Requirements Checklist for the Waste Feed Delivery System (4 Sheets)

\begin{tabular}{|c|c|c|c|c|c|}
\hline $\begin{array}{l}\text { Environment or } \\
\text { media }\end{array}$ & $\begin{array}{l}\text { Permit approval or } \\
\text { requirement }\end{array}$ & Citation & Agency & Affected actions & $\begin{array}{l}\text { Potentially } \\
\text { applicable }\end{array}$ \\
\hline \multirow{2}{*}{$\begin{array}{l}\text { Natıonal } \\
\text { Environmental } \\
\text { Policy Act and } \\
\text { Related Reviews }\end{array}$} & NEPA Documentatıon & $\begin{array}{l}40 \text { CFR } 1500 \text { to } 1508 \\
10 \text { CFR } 1021 \\
\text { DOE Order } 451 \text { 1A }\end{array}$ & $\overline{\mathrm{DOE}}$ & $\begin{array}{l}\text { Title II Desıgn (Projects) Pro } \\
\text { curement }\end{array}$ & Yes \\
\hline & $\begin{array}{l}\text { NEPA } 216 \text { Process/ } \\
\text { External Procurement }\end{array}$ & 10 CFR 1021216 & $\mathrm{DOE}$ & $\begin{array}{l}\text { Environmental Critıque before } \\
\text { lettıng external contract }\end{array}$ & No \\
\hline $\begin{array}{l}\text { Washington State } \\
\text { Environmental } \\
\text { Policy Act }\end{array}$ & SEPA Documentation & WAC 19711 & Ecology & $\begin{array}{l}\text { Actions requiring issuance of } \\
\text { permits licenses or other } \\
\text { approvals by state or local } \\
\text { authoritıes }\end{array}$ & Yes \\
\hline \multirow{7}{*}{$\begin{array}{l}\text { Other Tribal } \\
\text { Cultural } \\
\text { Historic and } \\
\text { Environmental } \\
\text { Planning and } \\
\text { Assessments }\end{array}$} & $\begin{array}{l}\text { American Indian Polıcies } \\
\text { Review }\end{array}$ & $\begin{array}{l}42 \text { USC } 1966 \\
\text { DOE Order } 12302\end{array}$ & $\begin{array}{l}\text { DOE } \\
\text { BIA }\end{array}$ & $\begin{array}{l}\text { Actions impactıng tribal } \\
\text { interests culture } \\
\text { environment or resources }\end{array}$ & No \\
\hline & $\begin{array}{l}\text { Cultural Resources } \\
\text { Review }\end{array}$ & $\begin{array}{l}10 \text { CFR } 1021 \\
36 \text { CFR } 63 \\
36 \text { CFR } 800 \\
43 \text { CFR } 7 \\
16 \text { USC } 461470 \mathrm{aa} \\
42 \text { USC } 1996 \\
42 \text { USC } 4321\end{array}$ & $\begin{array}{l}\text { DOE } \\
\text { State } \\
\text { Historic } \\
\text { Preservation } \\
\text { Office }\end{array}$ & $\begin{array}{l}\text { Any surface disturbance } \\
\text { buildıng modıficatıons or } \\
\text { other actıons affectıng areas } \\
\text { of archaeological or hıstorıc } \\
\text { significance Factlity changes } \\
\text { affectıng Hıstorıc Regıster } \\
\text { elıgıbılity }\end{array}$ & Yes \\
\hline & $\begin{array}{l}\text { Ecological Compliance } \\
\text { Review }\end{array}$ & $\begin{array}{l}10 \text { CFR } 1021 \\
50 \text { CFR } 17 \\
50 \text { CFR } 4026 \\
16 \text { USC } 703712 \\
16 \text { USC } 1531 \\
\text { DOE Order } 54841 \\
\text { WAC } 23212\end{array}$ & $\begin{array}{l}\text { USFWS } \\
\text { Ecology }\end{array}$ & $\begin{array}{l}\text { Surface disturbances } \\
\text { construction excavation or } \\
\text { other actions that modify } \\
\text { habitats or could affect } \\
\text { threatened or endangered } \\
\text { species }\end{array}$ & Yes \\
\hline & $\begin{array}{l}\text { Preoperational } \\
\text { Monitoring of Facility or } \\
\text { Site }\end{array}$ & DOE Order 54001 & $\overline{\mathrm{DOE}}$ & $\begin{array}{l}\text { Determination of baseline } \\
\text { environmental conditions } \\
\text { prior to new operations }\end{array}$ & Yes \\
\hline & Excavation Permit & $36 \mathrm{CFR} 800$ & DOE & $\begin{array}{l}\text { Any surface disturbance or } \\
\text { excavation }\end{array}$ & Yes \\
\hline & $\begin{array}{l}\text { DOE Acquisition/ } \\
\text { ES\&H Management }\end{array}$ & 48 CFR 915 and 970 & $\overline{\mathrm{DOE}}$ & $\begin{array}{l}\text { Integratıng Projects with } \\
\text { ISMS }\end{array}$ & Yes \\
\hline & $\begin{array}{l}\text { Price Anderson } \\
\text { Amendments Act }\end{array}$ & TOCFR 820 & DOE & $\begin{array}{l}\text { Facility corrections and } \\
\text { operational readiness }\end{array}$ & No \\
\hline All Air Emıssıons & Air Operatıng Permit & WAC 173401 & $\begin{array}{l}\text { Ecology } \\
\text { EPA } \\
\text { WDOH }\end{array}$ & $\begin{array}{l}\text { Construction or operations } \\
\text { with potential to emit } \\
\text { regulated compounds to air }\end{array}$ & Yes \\
\hline \multirow[t]{2}{*}{$\begin{array}{l}\text { Rodıoactive } \\
\text { Aır Emissions }\end{array}$} & $\begin{array}{l}\text { Source Review/NOC } \\
\text { NESHAPs }\end{array}$ & 40 CFR 61 Subpart H & EPA & $\begin{array}{l}\text { Construction or operations } \\
\text { with potential to emit } \\
\text { radionuclides }\end{array}$ & Yes \\
\hline & $\begin{array}{l}\text { Source Review/NOC } \\
\text { Radionuclides and } \\
\text { BARCT/ALARACT }\end{array}$ & WAC 246247 & WDOH & $\begin{array}{l}\text { Construction or operations } \\
\text { with potential to emit } \\
\text { radionuclides }\end{array}$ & Yes \\
\hline \multirow[t]{4}{*}{$\begin{array}{l}\text { Nonradioactıve } \\
\text { Air Emissions }\end{array}$} & $\begin{array}{l}\text { Prevention of } \\
\text { Significant } \\
\text { Deterioration }\end{array}$ & WAC 173400 & Ecology & $\begin{array}{l}\text { Construction or operations } \\
\text { with potentıal to degrade } \\
\text { exıstıng air qualtty }\end{array}$ & Yes \\
\hline & New Source Review & WAC 173400 & Ecology & $\begin{array}{l}\text { Construction of new sources } \\
\text { and modification of existing } \\
\text { sources of air emissions }\end{array}$ & Yes \\
\hline & $\begin{array}{l}\text { Toxic Air Pollutants } \\
\text { NOC and T BACT }\end{array}$ & WAC 173460 & Ecology & $\begin{array}{l}\text { Construction or operations } \\
\text { with potential to emit TAPS }\end{array}$ & Yes \\
\hline & $\begin{array}{l}\text { Outdoor/Unconfined } \\
\text { Burning Burn Permit }\end{array}$ & $\begin{array}{l}\text { WAC } 173425 \\
\text { BCAA Reg } 1 \text { Artıcle } 5\end{array}$ & $\begin{array}{l}\text { Hanford Fire } \\
\text { Department } \\
\text { BCAA }\end{array}$ & Open burning & No \\
\hline
\end{tabular}


HNF-2401

Revision 1

Table A-1 Environmental Permits, Approvals, and Requirements Checklist for the Waste Feed Delivery System (4 Sheets)

\begin{tabular}{|c|c|c|c|c|c|}
\hline $\begin{array}{l}\text { Environment or } \\
\text { media }\end{array}$ & $\begin{array}{l}\text { Pormit approval or } \\
\text { requirement }\end{array}$ & Citation & Agency & Affected actions & $\begin{array}{l}\text { Potentıally } \\
\text { applıcable }\end{array}$ \\
\hline \multirow[t]{2}{*}{$\begin{array}{l}\text { Drinking Water } \\
\text { Supply }\end{array}$} & $\begin{array}{l}\text { System ID Number } \\
\text { Engıneer Report Plans } \\
\text { and Specificatıons }\end{array}$ & WAC 246290 & $\overline{\text { WDOH }}$ & $\begin{array}{l}\text { Construction or operation of a } \\
\text { source for public or worker } \\
\text { drinking water }\end{array}$ & Yes \\
\hline & Operator Certification & WAC 246292 & WDOH & $\begin{array}{l}\text { Operation of a drinking water } \\
\text { supply }\end{array}$ & No \\
\hline \multirow[t]{4}{*}{$\begin{array}{l}\text { Domestıc Waste } \\
\text { Water Disposal }\end{array}$} & $\begin{array}{l}\text { Septic Systems Design } \\
\text { Approval }\end{array}$ & WAC 246272 & WDOH & $\begin{array}{l}\text { Construction or operation of } \\
\text { septıc dısposal systems with } \\
<14500 \mathrm{gal} / \text { day capacıty }\end{array}$ & No \\
\hline & $\begin{array}{l}\text { Septıc Systems Desıgn } \\
\text { Approval }\end{array}$ & WAC 173216 and 240 & Ecology & $\begin{array}{l}\text { Construction or operation of } \\
\text { septic disposal systems with } \\
>14500 \text { gal/day capacity }\end{array}$ & No \\
\hline & Pretreatment Permit & $\begin{array}{l}40 \text { CFR } 403 \\
\text { WAC } 173220 \\
\text { City Ordinance }\end{array}$ & $\begin{array}{l}\text { Ecology } \\
\text { City of } \\
\text { Richland }\end{array}$ & $\begin{array}{l}\text { Discharge of waste water to } \\
\text { public sanitary sewage } \\
\text { treatment system }\end{array}$ & No \\
\hline & $\begin{array}{l}\text { Wastewater Treatment } \\
\text { Facilıty Permit } \\
\text { Discharge Standards } \\
\text { Operator Certıfication }\end{array}$ & $\begin{array}{l}40 \text { CFR } 122 \\
\text { WAC } 173216 \text { and } 240 \\
\text { WAC } 173221 \\
\text { WAC } 173230\end{array}$ & $\begin{array}{l}\text { Ecology } \\
\text { EPA }\end{array}$ & $\begin{array}{l}\text { Construction or operation of } \\
\text { facility for treatment and } \\
\text { disposal of sanitary sewage }\end{array}$ & No \\
\hline \multirow{3}{*}{$\begin{array}{l}\text { Waste Water } \\
\text { Disposal to } \\
\text { Ground and Soll } \\
\text { Column }\end{array}$} & $\begin{array}{l}\text { Groundwater Qualıty } \\
\text { Standards }\end{array}$ & WAC 173200 & Ecology & $\begin{array}{l}\text { Disposal of pollutants that } \\
\text { could affect groundwater }\end{array}$ & Yes \\
\hline & $\begin{array}{l}\text { State Waste Discharge } \\
\text { Permit }\end{array}$ & WAC 173216 and 240 & Ecology & $\begin{array}{l}\text { Construction or operation of } \\
\text { facilitıes that discharge waste } \\
\text { water to ground }\end{array}$ & Yes \\
\hline & $\begin{array}{l}\text { Underground Injection } \\
\text { Control }\end{array}$ & WAC 173218 & Ecology & $\begin{array}{l}\text { Construction or operation of } \\
\text { facilitıes that dispose of waste } \\
\text { water in underground wells }\end{array}$ & No \\
\hline \multirow{8}{*}{$\begin{array}{l}\text { Construction and } \\
\text { Significant } \\
\text { Actions In or } \\
\text { Near Surface } \\
\text { Water }\end{array}$} & $\begin{array}{l}\text { Floodplain/Wetland } \\
\text { Assessment }\end{array}$ & 10 CFR 1022 & DOE & $\begin{array}{l}\text { Surface disturbances in } \\
\text { floodplain or near wetlands }\end{array}$ & No \\
\hline & $\begin{array}{l}\text { U S Army Corps of } \\
\text { Engineers Permit }\end{array}$ & 33 CFR 325 & USACE & $\begin{array}{l}\text { Construction or operations in } \\
\text { or near a river lake or other } \\
\text { surface water }\end{array}$ & No \\
\hline & Nationwide Permits & 33 CFR 330 & $\overline{U S A C E}$ & $\begin{array}{l}\text { Construction or operations in } \\
\text { or near a river or waterway }\end{array}$ & No \\
\hline & $\begin{array}{l}\text { Wild \& Scenıc River } \\
\text { Section } 10 \text { Permit }\end{array}$ & $\begin{array}{l}33 \text { CFR } 320 \\
33 \text { CFR } 322\end{array}$ & USACE & $\begin{array}{l}\text { Construction or operations in } \\
\text { or near a designated or } \\
\text { candidate wild or scenic river }\end{array}$ & No \\
\hline & $\begin{array}{l}\text { Hantord Reach Study } \\
\text { Act Notitication }\end{array}$ & PL 100605 & $\begin{array}{l}\text { U S Park } \\
\text { Service }\end{array}$ & $\begin{array}{l}\text { Construction within } 1 / 4 \text { mile } \\
\text { of the Columbia River }\end{array}$ & No \\
\hline & $\begin{array}{l}\text { Hydraulic Projects } \\
\text { Ptrmit }\end{array}$ & WAC 220110 & $\begin{array}{l}\text { State Dept } \\
\text { of Fisheries }\end{array}$ & $\begin{array}{l}\text { Construction or operations in } \\
\text { or near waters of the state }\end{array}$ & No \\
\hline & $\begin{array}{l}\text { Shoreline Development } \\
\text { Permit }\end{array}$ & WAC $1 7 3 \longdiv { 1 4 }$ to 20 & $\begin{array}{l}\text { Benton } \\
\text { County }\end{array}$ & $\begin{array}{l}\text { Construction or operations in } \\
\text { or near waters of the state }\end{array}$ & No \\
\hline & Aquatıc Lands Lease & WAC 33230 & $\begin{array}{l}\text { State Dept } \\
\text { of Natural } \\
\text { Resources }\end{array}$ & $\begin{array}{l}\text { Construction or operations in } \\
\text { or near waters of the state }\end{array}$ & No \\
\hline
\end{tabular}


HNF-2401

Revision 1

Table A-1 Environmental Permits, Approvals, and Requirements Checklist for the Waste Feed Delıvery System (4 Sheets)

\begin{tabular}{|c|c|c|c|c|c|}
\hline $\begin{array}{l}\text { Environment or } \\
\text { media }\end{array}$ & $\begin{array}{l}\text { Permit approval or } \\
\text { requirement }\end{array}$ & Citation & Agency & Affected actions & $\begin{array}{l}\text { Potentially } \\
\text { applicable }\end{array}$ \\
\hline \multirow[t]{4}{*}{$\begin{array}{l}\text { Waste Water } \\
\text { Disposal to } \\
\text { Surface Water }\end{array}$} & $\begin{array}{l}\text { NPDES Permit } \\
\text { Categorıcal Treatment } \\
\text { Standards }\end{array}$ & $\begin{array}{l}40 \text { CFR } 122 \\
40 \text { CFR } 405 \text { to } 471\end{array}$ & EPA & $\begin{array}{l}\text { Construction or operation of } \\
\text { facilities that treat and dispose } \\
\text { waste water to rivers lakes } \\
\text { and other surface waters }\end{array}$ & No \\
\hline & $\begin{array}{l}\text { Certification of NPDES } \\
\text { Permit }\end{array}$ & $\begin{array}{l}40 \text { CFR } 121 \\
\text { WAC } 173225\end{array}$ & $\begin{array}{l}\text { EPA } \\
\text { Ecology }\end{array}$ & $\begin{array}{l}\text { EPA issued NPDES permits } \\
\text { must be certıfied by Ecology }\end{array}$ & $\overline{\text { No }}$ \\
\hline & $\begin{array}{l}\text { Stormwater General } \\
\text { Permit under Waste } \\
\text { Discharge General } \\
\text { Permit Program }\end{array}$ & 40 CFR 122 & $\mathrm{EPA}$ & $\begin{array}{l}\text { Construction or operations } \\
\text { that could contribute } \\
\text { pollutants to stormwaters that } \\
\text { discharge to surface water }\end{array}$ & No \\
\hline & $\begin{array}{l}\text { Short Term Water } \\
\text { Qualıty Modificatıon } \\
\text { Approval }\end{array}$ & WAC $173201 \mathrm{~A}$ & Ecology & $\begin{array}{l}\text { Construction or operations } \\
\text { that could modify the quality } \\
\text { class of a surface water }\end{array}$ & No \\
\hline \multirow{3}{*}{$\begin{array}{l}\text { Radioactive } \\
\text { Materials and } \\
\text { Waste } \\
\text { Management }\end{array}$} & $\begin{array}{l}\text { General Radiation } \\
\text { Protection and } \\
\text { Monitorıng Programs }\end{array}$ & $\begin{array}{l}\text { DOE Order } 54001 \\
\text { DOE Order } 54005 \\
\text { DOE Order } 490\end{array}$ & $\mathrm{DOE}$ & $\begin{array}{l}\text { Construction or operations } \\
\text { with potential to emit } \\
\text { radionuclides }\end{array}$ & Yes \\
\hline & $\begin{array}{l}\text { Reprocessing of Spent } \\
\text { Nuclear Fuel }\end{array}$ & $\begin{array}{l}\text { Atomic Energy Act } \\
\text { DOE Order } 58202 \mathrm{~A} \\
\text { DOE Order } 64301 \mathrm{~A} \\
\text { DOE Order } 4351\end{array}$ & DOE & $\begin{array}{l}\text { Construction or operation of } \\
\text { facilities for storing treating } \\
\text { processıng and managing } \\
\text { spent nuclear fuel }\end{array}$ & Yes \\
\hline & $\begin{array}{l}\text { Management of High } \\
\text { Level and Low Level } \\
\text { Radıoactive Wastes }\end{array}$ & $\begin{array}{l}10 \text { CFR } 962 \\
40 \text { CFR } 191 \\
\text { DOE Order } 58202 \mathrm{~A} \\
\text { DOE Order } 64301 \mathrm{~A} \\
\text { DOE Order } 4351\end{array}$ & $\begin{array}{l}\text { DOE } \\
\text { EPA } \\
\text { Nuclear } \\
\text { Regulatory } \\
\text { Commission }\end{array}$ & $\begin{array}{l}\text { Construction or operation of } \\
\text { facilitıes for storing } \\
\text { packaging transporting and } \\
\text { disposing of high and low } \\
\text { level wastes }\end{array}$ & Yes \\
\hline \multirow[t]{6}{*}{$\begin{array}{l}\text { Solıd and } \\
\text { Dangerous Waste } \\
\text { Management }\end{array}$} & $\begin{array}{l}\text { Solid Waste Tacility } \\
\text { Permıt }\end{array}$ & WAC 173304 and 351 & $\begin{array}{l}\text { Ecology } \\
\text { Benton } \\
\text { Franklın } \\
\text { Health Dept }\end{array}$ & $\begin{array}{l}\text { Construction and operation of } \\
\text { facilities that manage solıd } \\
\text { and munıcıpal wastes }\end{array}$ & No \\
\hline & Waste Oıls & WAC 173303 & Ecology & $\begin{array}{l}\text { Receipt storage transport } \\
\text { recycling blending or } \\
\text { burning of waste oils }\end{array}$ & Yes \\
\hline & $\begin{array}{l}\text { Dingerous Waste Notice } \\
\text { of Intent }\end{array}$ & WAC 173303281 & Ecology & $\begin{array}{l}\text { Expansion construction or } \\
\text { modification and operation of } \\
\text { dangerous waste TSD facility }\end{array}$ & No \\
\hline & $\begin{array}{l}\text { Intcrim Status and Final } \\
\text { Status Standards }\end{array}$ & $\begin{array}{l}\text { WAC } 173303 \\
40 \text { CFR } 264265 \text { and } 270\end{array}$ & $\begin{array}{l}\text { Ecology } \\
\text { EPA }\end{array}$ & $\begin{array}{l}\text { Construction expansion or } \\
\text { modification of dangerous } \\
\text { waste TSD facility }\end{array}$ & Yes \\
\hline & $\begin{array}{l}\text { Pcrmits for Trials and } \\
\text { Demonstrations }\end{array}$ & $\begin{array}{l}\text { WAC } 173303807 \quad 808 \\
\text { and } 809\end{array}$ & Ecology & $\begin{array}{l}\text { Trial burns land treatment } \\
\text { demonstrations and research } \\
\text { involving dangerous waste }\end{array}$ & No \\
\hline & $\begin{array}{l}\text { Miscellaneous } \\
\text { Requirements for } \\
\text { Dangerous Waste } \\
\text { M unagement }\end{array}$ & 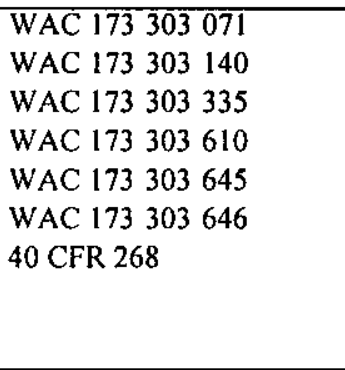 & $\begin{array}{l}\text { Ecology } \\
\text { EPA }\end{array}$ & $\begin{array}{l}\text { Exclusions for treatability test } \\
\text { samples Land disposal } \\
\text { restrictions Construction } \\
\text { quality assurance for } \\
\text { dnngerous waste } \\
\text { impoundment pile or landfill } \\
\text { Partıal or final closure of TSD } \\
\text { facılity Monitoring and } \\
\text { correctıve actions for } \\
\text { dangerous waste releases }\end{array}$ & Yes \\
\hline
\end{tabular}


Table A-1 Environmental Permits, Approvals, and Requirements Checklist for the Waste Feed Delivery System (Sheet 4 of 4 )

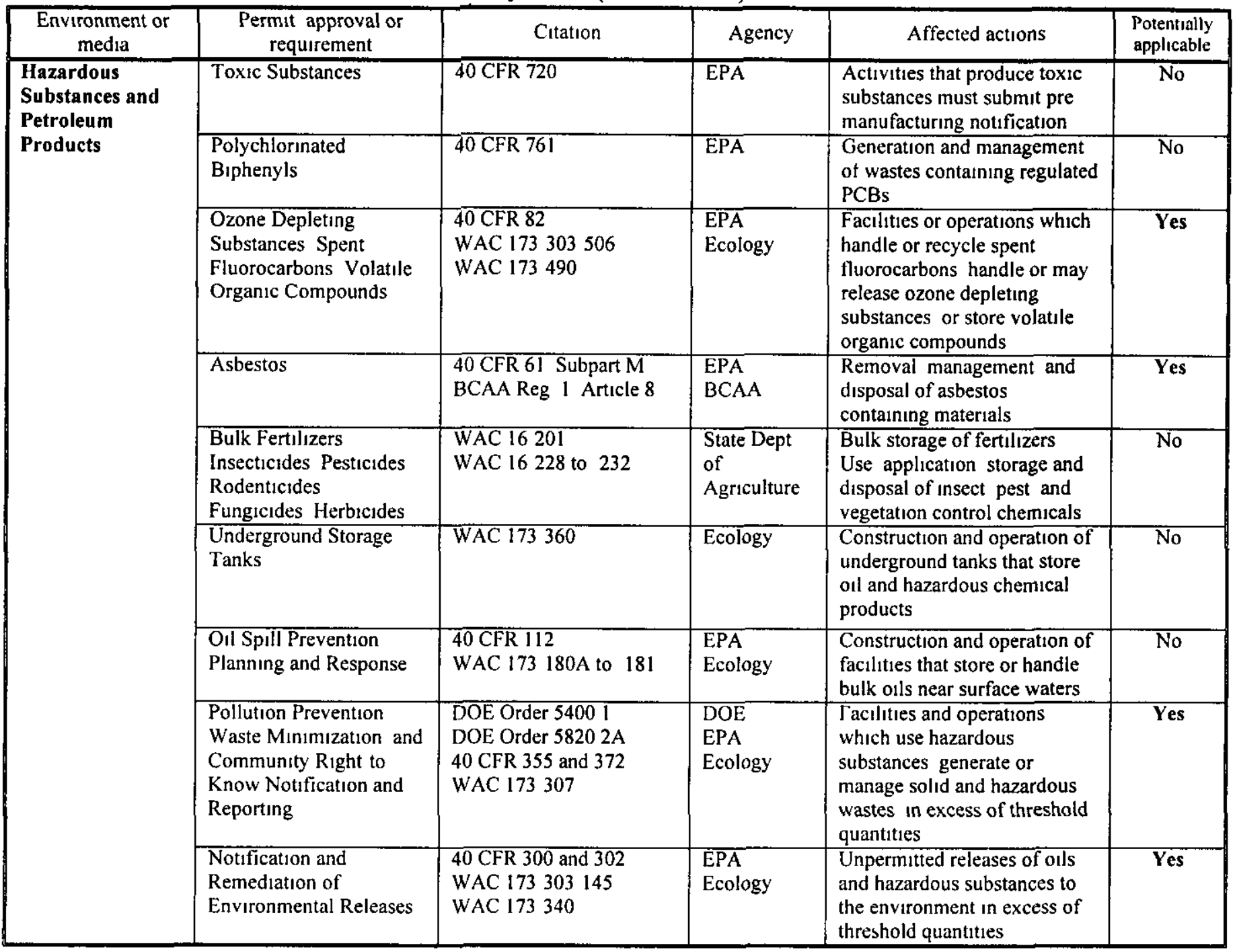


HNF 2401

Revision 1

\section{ENVIRONMENTAL PERMITS, APPROVALS AND REQUIREMENTS NARRATIVE FOR THE WASTE FEED DELIVERY SYSTEM}

\section{NATIONAL ENVIRONMENTAL POLICY ACT (NEPA) AND RELATED REVIEWS}

\section{NEPA Documentation}

National Environmental Policy Act of 1969 (NEPA) implementing regulations require preparation of an environmental impact statement (EIS) for major federal actions that significantly affect the quality of the human environment The EIS results in a record of decision (ROD) The NEPA regulations require that if there is uncertainty about the necessity for an EIS an environmental assessment (EA) should be prepared An EA documents analysis of a proposed action through evaluation of its potential impacts on the environment The EA provides the information for determining the need to prepare an EIS, or results in a finding of no significant impact (FONSI) determination The NEPA regulations also list categories of actions that normally do not require an EIS or $E A$ and which qualify for categorical exclusion $(\mathrm{CX})$, documentation of the bases for CXs still must be completed The general scope of each of these types of NEPA documentation is as follows

Environmental Impact Statement An EIS is required if it is determined that the proposed action will have impacts to the human environment that might be significant A Notice of Intent published in the Federal Register officially starts the EIS process A draft EIS is published describing a proposed action and alternatıves The final EIS is published after incorporating public comments The EIS process results in publication of the ROD in the Federal Register Finally, a Mitigation Action Plan is prepared detailing specific mitıgatıve measures relating to the final EIS and ROD

Supplement Analysis A Supplement Analysis is prepared if there are substantial changes or potentially significant new circumstances or information relevant to environmental concerns for an action covered by an existing EIS with a ROD Approval authority for the Supplement Analysis usually is delegated to the responsible DOE field office if the applicable EIS is delegated by the DOE Secretary

Environmental Assessment An EA is a concise document with alternatives to a proposed action The EA analyzes the environmental consequences of the proposed action and the alternatives to that action including the consequences of accidents and routine operations and the cumulative and long-term impacts The relationship of the proposed action to federal, state, and local land use plans, policies, and regulations also is discussed in the EA The EA has three defined functions provide sufficient information to determine whether a proposed action requires an EIS or is eligible for a FONSI, provide an interdisciplinary review of a proposed action and alternatives to analyze their potential environmental impacts, facilitate preparation of an EIS if one is determined to be needed 
Categorical Exclusion If the potential impacts to the environment of a proposed action are within the integral elements and clearly outside of extraordinary circumstances and the proposed action falls within a category of actions not normally requiring an EA or an EIS the action may be eligible for a CX All DOE CXs are listed in the NEPA implementing regulations If no pre approved sitewide categorical exclusion exists, a CX is prepared describing the action and identıfying the appropriate CX

Sitewide Categorical Exclusion All sitewide categorical exclusions are reviewed and approved periodically by DOE and are listed on the Hanford IntraNet The sitewide categorical exclusions could be slightly modified from those CXs listed in DOE regulations, and are specific for use by the Hanford Site The sitewide categorical exclusion actions must still meet all integral elements and be outside of any extraordinary circumstances as depicted in the regulations

The NEPA documentation process begins by identıfying the purpose, scope, and location of a proposed action If a proposed action appears to be covered under an existing approved EIS or EA, the relevant ROD or FONSI should be examined to ensure the proposed action is adequately bounded by existing documentation If it is determined that a proposed action is not covered by existing environmental documentation, the action would be evaluated for coverage under the established CXs (including sitewide categorical exclusions) If the proposed action is covered by a CX, a memorandum is prepared that summarizes the proposed action and its background, along with an explanation of how the action meets the minimum requirements of a $\mathrm{CX}$

If a proposed action is not adequately covered by an existing approved EIS, EA or CX, DOE will decide whether the action warrants an EA, a Supplement Analysis to an existing EIS a supplemental environmental impact statement (SEIS) or a full EIS If an EA is prepared the EA results in a final determination that either the proposed action is a major action significantly affectıng the environment and requires an EIS or a FONSI should be issued If a proposed action is similar to an action addressed in an existing EIS DOE could elect to prepare a SEIS A Supplement Analysis is prepared when it is unclear if a SEIS is required The Supplement Analysis should contain sufficient information for DOE to determine whether the existing EIS should be supplemented, a new EIS should be prepared, or no further NEPA documentation is required

Evaluatıon The overall scope of projects and activities supporting development of the WFD system are addressed in a large body of existing NEPA documentation, including the following

- Safe Interm Storage of Hanford s Tank Waste Final Environmental Impact Statement (DOE 1995)

- Record of Decisıon for Safe Interım Storage of Hanford Tank Wastes (60 FR 61687)

- Tank Waste Remediation System Hanford Site Richland Washington Final Environmental Impact Statement (DOE 1996) (TWRS EIS) 
HNF-2401

Revision 1

- Record of Decısıon for the Tank Waste Remediatıon System (62 FR 8693)

- Supplement Analysis for the Proposed Upgrades to the Tank Farm Ventllation Instrumentation and Electrical Systems Under Project W-314 in Support of Tank Farm Restoration and Safe Operations (DOE 1997a)

- Supplement Analysis for the Tank Waste Remediation System (DOE 1998a)

- Hanford Site Tank Waste Remediation System Programmatic Environmental Review Report (DOE 1998b)

The WFD system will also depend on the performance of numerous low impact tasks which are covered under existing CXs or sitewide categorical exclusions In general, it appears that the NEPA documentation record adequately bounds the range of impacts associated with the current WFD system configuration This position will be reviewed periodically as environmental requirements for construction and operations are evaluated during project/actıvity management planning Adequacy of existıng NEPA coverage will, if necessary, be confirmed in writing with the DOE NEPA Compliance Officer If it appears that the scope of a particular project/activity is not suitably covered in existing NEPA documents, it is assumed that DOE may require development of an EA, and it is assumed that the result of an EA would be either a recommendation for a FONSI or to prepare a Supplement Analysis No circumstances are anticipated at this time that would lead to having to prepare an SEIS The decision for most appropriate NEPA documentation will be made by the DOE NEPA Compliance Officer

\section{NEPA 216 Process/External Procurement}

For those procurement actions with potential environmental liabilities, which are not adequately addressed in existing NEPA documentation, DOE may require the offerors to submit data and information so environmental impacts can be evaluated prior to placing the external contract Bidder proposals would typically be evaluated for potential environmental impacts effectiveness of proposed mitigation potential bidder responsibilities for environmental compliance past compliance history, and other relevant information The NEPA compliance guidelines in the implementing regulations must be followed and the results issued in an Environmental Critique Evaluation results must also be approved by the DOE NEPA Compliance Officer prior to final contract These evaluations become part of the formal procurement documentation and may be published as part of the public record

Evaluation It is assumed that existing NEPA documentation sufficiently covers the range of WFD system services for which contractor support may be procured The NEPA 216 and Environmental Critique process is not expected to apply to the current scope of WFD system projects and activities 


\section{WASHINGTON STATE ENVIRONMENTAL POLICY ACT (SEPA)}

\section{SEPA Documentation}

The Washington State Environmental Pollcy Act (SEPA) Rules are promulgated and managed by the Washington State Department of Ecology (Ecology) SEPA requires evaluation by a state or local agency (the "lead agency") of environmental impacts associated with a proposed action under its jurisdiction before approving or disapproving the action The SEPA review process usually is triggered whenever a state or local action is required, such as issuing or modifying a state or local permit SEPA encourages the grouping of similar, related actions (e $g$, all necessary permits and approvals) withın a single SEPA review so that all associated impacts can be considered at once

The typical method of addressing SEPA requirements is to complete a SEPA environmental checklist that provides information necessary for the lead agency to make a threshold determination on the significance of the proposed action If the proposed action is categorically exempt or nonsignificant further action under SEPA is not required If the proposed action is significant, preparation of a SEPA EIS is required An option exists for adoption of existıng NEPA document(s) (e $g$, a NEPA EIS) to fulfill the lead agency's responsibilities

On the Hanford Site the SEPA process begins when approval(s) or modification(s) (e g , license, permit) must be obtained for a proposed action to proceed A SEPA checklist may be prepared and submitted with the license or permit application Alternatively, when a proposed action has been addressed under NEPA documentation, such as an approved EIS/ROD or EA/FONSI, the lead agency may be asked to adopt the NEPA documentation in lieu of the SEPA checklist The lead agency (If it is not Ecology) may request Ecology's determination on the adequacy of the NEPA documentation to satısfy the SEPA requirements The DOE NEPA Complance Officer will forward copies of the NEPA documentation and/or SEPA checklist to the lead agency If the agency concurs, a separate Determination of Nonsignificance and Statement of Adoption are published under SEPA to correspond with the NEPA ROD or FONSI

Evaluatıon It is assumed that the lead agency for SEPA determınations regardıng current and known future WFD system projects and activities will be Ecology Ecology was a co-preparer of the TWRS EIS (DOE 1996) and has concurred with the associated ROD and subsequent Supplement Analysis Past experience with Ecology indicates a willingness to accept existing NEPA documentation as sufficient under SEPA, as long as the NEPA process bounded the range of environmental impacts that SEPA covers It is expected that an independent SEPA process will not be required for the WFD system (including known future upgrades) and that Ecology will find the existing NEPA documentation to be adequate for satısfying SEPA requirements It is expected that this position may need to be corroborated, through occasional information letters from the DOE NEPA Compliance Officer to Ecology, as the scope of the WFD system is further refined The need for corroboratıve documentation will depend on the scope and extent of each project or activity, and will be the decision of the DOE NEPA Compliance Officer 
HNF-2401

Revision 1

\section{OTHER TRIBAL, CULTURAL, HISTORIC, AND ENVIRONMENTAL PLANNING} AND ASSESSMENTS

\section{American Indıan Tribal Government Agreements}

American Indian Tribal Governments have a special and unique legal relationship with the U S Federal Government and its agencies These are defined in numerous treaties, statutes, historical precedents, and the U S Constitution In addition, the state of Washington has agreements respecting current and future use of the lands surrounding the Hanford Site All actions on the Hanford Site which may impact these agreements must be approved by DOE The Cultural Resources Review (see following discussion) will be the mechanism for identifying potential impacts

Evaluatton It is assumed that current and known future actions associated with the WFD system are consistent with existing Natıve American Tribal agreements This will be confirmed through periodic Cultural Resources Reviews in support of specific projects and activities, and will be further verified with the DOE lead for Tribal affarrs as the scope of the WFD system is further refined

\section{Cultural Resources Review}

A review for resources of special historic or cultural value shall be performed for any project involving demolition, modification, or deactivation of a potentially significant facility or structure The Cultural Resources Review must be made before initıating any external surface-disturbing activities onsite, or if any modifications are planned for any facility with the potential for inclusion on the National Register of Historic Places Projects and major activities will be expected to complete this review, in coordination with representatives from the Hanford Cultural Resources Laboratory (HCRL) A walkthrough of the affected area(s) may be necessary to assess the cultural resources of the site historic buildings and structures prior to any construction or decommissioning activities This assessment will locate and identify any artifacts which have importance for Native American preservation, or which have interpretive or educational value as exhibits within local, state, or national museums

Evaluatıon A Cultural Resources Review has been performed (initially in 1994 and periodically updated) for the tank farms, and a general exemption for tank farm reviews has been issued (Crist 1994) The general exemption encompasses the areas inside or within $150 \mathrm{~m}$ of the 200 East/200 West tank farm boundaries, and most (if not all) actions associated with the WFD system are located within these areas It is assumed that projects and activities supporting the WFD system will be able to rely on the general cultural resources exemption Project/activity representatıves should coordinate with the facility ECO during initial planning stages to determine if the general resources exemption covers the planned work scope and areas If work may affect non-exempted areas, and the work areas have not been previously reviewed, the facility ECO should request a Cultural Resources Review and HCRL support 
HNF-2401

Revision 1

Projects and activities will be reviewed by the facility ECO during the excavation permit review (see following discussion) to confirm that cultural resources have been adequately surveyed and protected

\section{Ecological Compliance Review}

A site survey should be performed to identıfy any plant or animal species protected under the Endangered Species Act, candidates for such protection, species listed as threatened, endangered, candidate, sensitive, or monitored by the state of Washington, and species protected under the Migratory Bird Treaty Act Also assessed is whether the planned activities have the potential to disturb any priority habitats and/or species identified in the survey The Ecological Compliance Review also covers taking possession, transportation, sale, purchase/barter export or import of special status plants and animals (both living and dead) The Ecological Compliance Review fulfills the NEPA ecological/biological review requirement

Evaluatıon A blanket biological review has been performed (initially in 1995, and periodically updated) for the tank farms, assessing the areas for significant habitats and species (Brandt 1999) It is assumed that projects and activities supporting the WFD system will be able to rely on the blanket biological review for most work areas Some projects may be constructing facilities outside the blanket biological review coverage area and would need to perform supplemental reviews Projects and activities are expected to satisfy the conditions of the applicable biological review Project/activity representatives should coordinate with the facility ECO during initial planning stages to determine if the blanket biological review provides adequate coverage and what actions are required to meet the blanket conditions If necessary an independent assessment should be conducted to supplement the blanket review and ensure the Ecological Compliance Review requirement is met During the excavation permit review (see following discussion), the facility ECO will evaluate and confirm that the blanket biological review (and supplemental assessment if needed) adequately covers the work scope and that appropriate protective measures (if necessary) are implemented

\section{Pre-Operational Monitoring of Facilities, Sites, and Operations}

A pre-operational environmental study shall be conducted before startup of a site, facility, or process that has the potential for significant adverse environmental impact The purpose of this study is to determine pre-existing, or baseline, environmental conditions prior to development of the facility site, or operations The study includes evaluating environmental concentrations of chemicals and radionuclides This study should begin not less than one year (preferably two years) before startup, so seasonal changes can be evaluated

A facility effluent monitoring plan (FEMP) determination is performed to assess the need to prepare a FEMP The radioactive and chemical source terms must be reviewed, and if one of the two thresholds can be exceeded, a FEMP must be prepared If not, a one page form is sufficient to document the determination The sitewide environmental monitoring plan (EMP) will be updated automatically, no facility specific effort is required The 
HNF-2401

Revision 1

monitoring of effluents and the environment is documented formally each year All RPP activities are included as appropriate, and the monitoring and collection of meaningful data requires routine interaction with other onsite contractors to ensure activities are integrated without duplication of effort Numerous reports are published annually for the Hanford Site, addressing environmental releases, radionuclide and non-radioactive air emissions, and general Hanford Site environmental conditions

Evaluation A substantial amount of environmental data exists and is collected on an ongoing basis for the tank farms The following documents have been prepared to comply with the requirements for environmental monitoring at the Hanford Site and the RPP

- Environmental Monitoring Plan - United States Department of Energy Richland Operations Office (DOE 1997b)

- Faclltty Effluent Monttoring Plan for the Tank Farms Facilitıes (Crummel et al 1999)

Some of the key effluent and environmental monttoring reports include the following

- Environmental Releases for Calendar Year 1997 (Gleckler 1998)

- Hanford Site Near Faciltty Environmental Monitoring Annual Report Calendar Year 1997 (Perkins et al 1998)

- Hanford Site Environmental Report for Calendar Year 1998 (Dirkes et al 1999)

This information should satisfy many of the pre-operational monitoring requirements that are likely to apply to the WFD system, and it is expected that most supporting projects and activities will not be required to institute separate pre-operational monitoring programs In some cases however facilities or operations may occur in areas, may affect environmental media or biota, or may involve potential emissions for which currently avalable monitoring does not provide sufficient baseline information In these cases, it may be necessary for the project or activity to support pre-operational monitoring for at least one year before beginning construction or operations Project/activity representatives should coordinate with the facility ECO durıng initial planning stages to determine whether an adequate environmental baseline has been established for their scope of work, or whether additional pre-operational monitoring will be required

\section{Excavation Permit}

An excavation permit is required before initiating any potential surface disturbing onsite activities The facility ECO may review and approve excavation permits before excavation begins, to ensure that all environmental, cultural and ecological resource reviews have been completed The excavation permit review process will also consider proposed locations for all underground piping, pits pads and support structures and should evaluate for possible intrusion into radiation control areas, underground 
contamination areas and buried tanks to avoid unanticipated exposures The excavation permit offers an opportunity to identify unusual or uncertain compliance, safety, operations, or environmental issues

Evaluation Excavation permits will be required for most of the projects and activities supporting the WFD system Developing the information needed to support excavation permit approvals is the responsibility of each project or activity It is assumed that initial planning discussions between the project/activity representatives and the facility ECO will have identified and addressed any significant cultural resource or ecological compliance issues prior to completion of excavation permits, and that necessary approvals will not be delayed for cultural or ecological causes It is also assumed that other environmental compliance issues will be resolved prior to, and will not be causes of delay for, WFD system excavation permits

\section{DOE Acquisition Regulations and ISMS Interfaces}

All DOE contractors must have an Environment, Safety and Health Management System in place and implemented to minimize environmental impacts of a project Project management shall ensure that actions are integrated through the site-wide Integrated Environment, Safety and Health Management System (ISMS) Each project and activity must ensure that ISMS is implemented in their work

Evaluation The facility ECO will ensure that applicable environmental requirements are identified and implemented for the WFD system, consistent with the requirements and objectives of the ISMS

\section{Price-Anderson Amendments Act (PAAA) Review}

If a project or corrective action is being done in response to a deficiency or nonconformance under the Price-Anderson Amendments Act (PAAA), then the closure authority (defined in the PAAA determination and listed in the site Deficiency Tracking System database) and the Legal Office must also review the project scope, the NEPA determination, and the permits which will redefine closure of the deficiency and provide a basis for restart of the facility/process Additional PAAA guidance is avalable on the Hanford Intranet

Evaluatıon There are no current PAAA deficiencies or non-conformances being closed or resolved by the WFD system supporting projects or activities

\section{ALL AIR EMISSIONS}

\section{Arr Operating Permit (AOP)}

State regulations establish a comprehensıve Washıngton State Aır Operatıng Permit (AOP) program that meets the requirements of Title V of the Federal Clean Atr Act 
(CAA) and has been approved by the U S Environmental Protection Agency (EPA) A single site-wide permit the Hanford AOP, is required for the Hanford Site, signatories to the Hanford AOP include DOE, Ecology, the Washıngton State Department of Health (WDOH) and the Benton Clean Air Authonty (BCAA) The AOP covers both radioactive and non-radioactive alrborne emissions from all emission units that meet significance criteria defined by the CAA and applicable state regulations An emissions release source is considered significant if it has the potential to contribute more than one percent of the total Hanford Site's exposure to the general public Aurborne emissions include, but are not limited to, criteria pollutants, toxic and hazardous air pollutants, and radionuclides Ecology also has established thresholds for regulated pollutants below which emissions are considered insignificant (Insignificant Emission Units, or IEUs) for the purposes of the AOP program Activities, facilities or components that qualify as IEUs must comply with general standards, but are exempt from the administrative requirements of the AOP

Evaluation The Hanford AOP is nearing final approval Once approved, all air emission sources on the Hanford Site will be subject to the specific operating conditions established by the Hanford AOP Many WFD system supporting projects and activities are expected to affect air emission sources that are covered by the Hanford AOP Work associated with the WFD system will likely be subject to coverage under the Hanford AOP if it involves construction of new air emission sources, modification of existing air emission sources, or changes in operating practices for permitted sources Procedures for updating the Hanford AOP are under development, and will need to be coordinated with the Notice of Construction (NOC) requirements for new and modified air emission source reviews (see following discussions) Project/activity representatıves should coordinate with the facility ECO durıng initial planning stages to evaluate potential compliance requirements under the Hanford AOP

\section{RADIOACTIVE AIR EMISSIONS}

\section{Source Review and Notice Of Construction, National Emission Standards for Hazardous Atr Pollutants (NESHAPs)}

Any new stationary source of radionuclide emissions is subject to a preconstruction review and approval by the EPA Also, any new physical or operational activity that will provide any increase in potential emissions of radionuclides is defined as a modification and may require approval Approval is obtained by submitting an NOC for approval to construct or modify Sampling and monitoring systems and additional operational records are required by National Emission Standards for Hazardous Air Pollutants (NESHAPs) designation The EPA requires the sampling and monitoring system to meet specific criteria when the effective dose equivalent to the maximally exposed offsite individual resulting from the activity is $01 \mathrm{millirem}$ per year or greater (assuming normal operations and no emissions control equipment in place) A facility may already have a completed FEMP, which may only need revision if the existing stack/emission point is registered and continuously monitored for compliance 
Evaluatıon The WFD system involves facilities and components that emit radionuclides, and these emissions are subject to review and approval by EPA under the NESHAPs program It is expected that most projects and activities will need to evaluate therr work scope for NESHAPs applicability, and in many cases will have to support an NOC submittal and approval effort It is also assumed that appropriate radionuclide air emissions monitoring and control technology will be incorporated, as necessary, into project and activity designs, and that such designs will be subject to EPA review and approval through the NOC process Project/activity representatives should coordinate with the facility ECO during initial planning stages to evaluate potential NESHAPs compliance requirements

\section{Source Review and NOC, Radiation Protection-Air Emissions}

In addition to EPA, WDOH regulates radioactive air emissions in Washington State under authority delegated by the Nuclear Regulatory Commission Any new activity (including any new construction work), process, or equipment that will involve potential emissions of radionuclides to the air is subject to a pre construction review and approval by the WDOH If the activity involves a physical or operational change at an existing source of radionuclide air emissions and the change will result in any increase in the rate of emissions of radionuclides to the ambient air from the existing source, review and approval by the WDOH is required To determine if increased emissions are likely to occur emissions expected after the changes are compared to an emissions baseline (normally the annual rate of emissions observed from the facility, structure, or operation during the prior two years of operations) The increase may be related to such factors as increased flow rate or concentration of effluent, upstream heatıng or mixing of source material, or increased exposure to outside air When determining whether increased emissions would occur, additional abatement by any planned emissions control equipment must not be factored in

The WDOH requires the use of best avallable radionuclide control technology (BARCT) for all significant modifications or the use of as low-as-reasonably-achievable (ALARA) control technology (ALARACT) for all nonsignificant modifications A BARCT assessment evaluates the universe of avallable control technologies and selects the most effective control technology from all known feasible alternatives The ALARACT assessment requires the use of radionuclide emission control technology that achieves emissions levels that are consistent with the philosophy of ALARA This is demonstrated by evaluatıng the control system in relation to applicable technology standards and other control technologies that have been operated successfully in similar applications A significant modification is one where the potential-to-emit airborne radioactivity is at a rate that could increase the total effective dose equivalent to the maximally exposed offsite individual by 10 millirem per year or more (assuming normal operations and no emissions control equipment in place)

An NOC application must be filed to obtain prior WDOH approval of the new or modified activity The NOC must also include estımates of actual and potential emissions and an assessment of BARCT or ALARACT If an NOC is required, the same data may 
HNF-2401

Revision 1

be combined for both WDOH and EPA The WDOH currently makes a case-by-case determination regarding the need to register any new or modified source of radioactive air emissions based on data from the NOC

Evaluation The WFD system involves facilities and components that emit radionuclides, and these emissions are subject to review and approval by WDOH It is expected that most projects and activities will need to evaluate their work scope for increased radionuclide emissions and will have to support an NOC review process It is expected that in many cases it will be necessary to implement monitoring and control technologies for at least the construction phases of WFD system work Future operations that will occur as a result of the project/activity may also need to be evaluated for monitoring and control requirements It is possible that some actıvities involving "routıne' operations or maintenance may be able to qualify for the conditions agreed to with WDOH in Control of Airborne Radioactive Emissions for Frequently Performed TWRS Work Activities (ALARACT Demonstrations) (Clark 1999), in which case the complete NOC review process may not be required In these cases predefined control and monitoring practices would be applied to the activity Project/activity representatives should coordinate with the facility ECO during initial planning stages to evaluate potential compliance requirements

\section{NON-RADIOACTIVE AIR EMISSIONS}

\section{Prevention of Significant Deterioration (PSD)}

Any significant increased emission of criteria pollutants (e g, particulates, carbon monoxide, nitrogen oxides) from a new or modified operation or construction may trigger a major modification Expected increases shall be considered in conjunction with total Hanford Site emissions to determine if a PSD permit is needed or if the increases would affect an existing permit Pre construction approval could be required by Ecology If an NOC is required, the potential annual emissions of criteria pollutants must be estımated and included

Evaluation The WFD system involves facilities and components that emit criteria pollutants, so the PSD requirements are potentially applicable However, it is likely that current and known future work associated with the WFD system will not result in significant increases of criteria poliutants It is assumed that a PSD permit will not be necessary for most, if not all, WFD system actions but project/actıvity representatives should coordinate with the facility ECO during initial planning stages to confirm that PSD approval will not be required for their scope of work The determination regarding PSD compliance should be coordinated with the New Source Review (NSR) process (see following discussion) and documented (most likely by letter to file) 
HNF-2401

Revision 1

\section{New Source Review}

Any new activity project, process, or equipment that will involve potential emissions of contamination to the air is subject to an NSR and pre-construction approval by Ecology If the activity involves a physical or operational change at an existing source of air emissions, and the change will result in any increase in the rate of contaminant emissions to the ambient air from the existing source, this may be considered a modification requiring Ecology NSR and approval Information about the new or modified source is submitted to Ecology in an NOC, which must include a description of the new construction or modification actıvities, estimates of actual and potential emissions, and an assessment of best avallable control technology to be used

Evaluation Constructing and operatıng the WFD system is expected to affect many existing sources of air emissions, and to add new sources that do not currently exist Each project or activity will need to be separately assessed with respect to potential for emissions significant enough to warrant an NSR and pre-construction approval Project/actıvity representatıves should coordinate with the facility ECO during initial planning stages to determine if an NSR and Ecology approval will be required for their scope of work Final determination would be documented either through an NOC submittal (If NSR and approval are necessary), or else by letter to file (including possible confirmatory correspondence with Ecology) indicating an NSR and approval are not required

\section{Toxic Aur Pollutants (TAPs), NOC and Control Technology for Toxics}

Any new or modified sources of air emissions must be assessed for possible emissions of Toxic Air Pollutants (TAPs) The TAPs evaluation must consider all potential and/or measurable emissions If emissions exceed apphcable small quantity emission rates, dispersion modeling must be performed to demonstrate that the offsite concentration for each constituent does not exceed its applicable acceptable source impact level (ASIL) For constituents without a small quantity emission rate, dispersion modeling also is required Ecology requires the submittal and subsequent approval of an NOC for the construction of new sources of TAPs, the modification of an existing source that increases its emissions (increase is calculated based on conditions existing before modification of the source) or, the replacement or substantial alteration of the emissions control technology at an existing source The TAPs regulations mandate the use of best avalable control technology for toxics (T-BACT) Reasonably avallable control technology is required for projects when TAPs decrease or remain stable

Evaluation Current information about the tank farms indicates a potential to emit organic compounds, ammonia, and possibly other non-radioactive constituents to the atmosphere during certain tank farm operations (e g, mixing air lift circulation sluıcing transfer) It is not known whether all of the possible constituents are TAPs, or whether possible emission rates would exceed the small quantity emission rates or could exceed ASILs For now, it is assumed that actions supporting the WFD system may be subject to the TAPs requirements, and may need to submit an NOC for Ecology approval this also implies that installation and operation of $\mathrm{T}$. 
BACT may be necessary Only the combined ventilation system for the AY and AZ tank farms is presently fitted with toxics control devices, the other DST ventilation systems do not include toxics treatment capabilities As part of the WFD system definition process, efforts are under way to determine what if any, upgrades should be made to the DST ventılation systems Pending completion of these efforts, projects and activities representatıves will need to work with the facility ECO to determine whether or not their particular scope of work is likely to require an NOC submittal and approval for TAPs air emissions

\section{Outdoor/Unconfined Burning, Burn Permit}

Any use of unconfined burning requires a permit from the BCAA obtained through the Hanford Fire Department Special burn permits are required for demolition or fire training

Evaluation Projects and activities supporting WFD system development are not expected to engage in any outdoor or unconfined burning, so these requirements are not expected to be applicable

\section{DRINKING WATER SUPPLY}

\section{Drınkıng Water System Identıficatıon, Approval of Engıneerıng Reports, Plans and Specifications}

New drınkıng water systems must obtain an identıfication number from the WDOH before operation WDOH must review and approve required engineering reports, plans and specifications for a drinking water supply system before construction Modifications and upgrades to existing systems must be in accordance with the approved plans and specifications and must comply with applicable WDOH water supply regulations

\section{Drınkıng Water System Operator Certıfication}

Operators in direct responsible charge of certain public water systems must be examined and certıfied for their competency on state requirements and standards before operatıng the system Systems requirng certified operators include systems with 100 services at any one time, or systems serving 25 or more persons where the water is supplied from a stream, lake or other surface water source and the systems are required by law to use a water filtration system

Evaluatıon The WFD system will rely on existıng Hanford Site drinking water systems, and current and known future work is not expected to impose so large a demand for fresh water that major expansion of the supply system will be needed Modification of existing water supply systems to extend service to existing use areas is assumed to be within normal maintenance activity and should not require WDOH approval However, the Hanford Site Water Purveyor must review and approve of tie-ins to fresh water supplies (e $g$, drinkıng water in new buildings fire suppression, dilution and flush water), and of equipment or facilities that will be 
located near or could otherwise affect water supply systems The Water Purveyor is authorized to ensure that site drinkıng water systems are installed and operated in compliance with the WDOH standards and approved Hanford Site plans and specifications Project/activity representatives should coordinate with the Water Purveyor and the facility ECO during initial planning stages to evaluate proposed work for consistency with the applicable water system requirements

\section{DOMESTIC WASTE WATER DISPOSAL}

\section{Septıc Systems With Design Capacity of 14,500 gal/day and Less}

Plans and specifications for construction of a new sanitary septic system or modification of an existing system must be reviewed and approved by WDOH before construction or entering into a contract for construction WDOH's current position is to not allow modification or expansion of a drainfield located in the area of a known subsurface chemical hazard that could potentially cause the plume to harm groundwater Once an approved system is complete, a professional engineer registered in Washington State must certify that the installation was done according to the plans and specifications approved by WDOH In addition an operation and maintenance manual must be submitted to WDOH

\section{Septic Systems With Greater Than 14,500 gal/day Design Capacity}

Septıc systems with design capacities greater than $14,500 \mathrm{gal} /$ day are regulated by Ecology These systems are considered to be disposing of waste water to the ground or soll column (discussed further below) and require a state waste discharge permit (SWDP) issued pursuant to state water quality regulations These systems are also subject to the engineering report, plan, and specification approval processes described in the applicable regulations

Evaluatıon The tank farms have desıgnated change facilities, with operational septic systems, permitted under full-use assumptions Temporary facilities (e $\mathrm{g}$, portable tollets) that do not require septic discharges are established as needed to support short duration construction in areas where services are not immediately avallable It is assumed that the WFD system will not result in increases to or addition of septic discharge facilities, so the septic system standards are expected to not be applicable

\section{Pretreatment Permit}

Operations and facilities that discharge waste water to a municipal sewage treatment plant (either directly or via the sanitary sewer) may be required to obtain a pretreatment permit or approval from the local authority (e g, City of Richland Public Works) The need for a pretreatment permit depends on whether the activity is considered a Significant Industrial Discharge or fits a national pretreatment category 
HNF-2401

Revision 1

\section{Discharge Standards, Effluent Limitations, and Operator Certification for Domestic Waste Water Facilities}

Effluent from domestic waste water treatment facilities (except subsurface septic tank systems with capacities of $14,500 \mathrm{gal} /$ day and less) must meet applicable effluent limits and discharge standards established by Ecology Every operator in responsible charge of a domestic waste water treatment plant is required to be certıfied at a level equal to or higher than the classification rating of the treatment plant being operated Operator certification is not required for septic systems

Evaluatıon Some septic wastes are pumped from tank farm sanitary waste holding facilities and transported offsite for disposal at a municipal treatment plant However industrial waste water is not discharged to these systems, so the pretreatment standards do not apply In addition the tank farms do not operate a domestic waste water treatment facility, so the relevant standards would not apply Projects and activities associated with the WFD system are not expected to be subject to the permitting and other standards for discharges to or operation of domestic waste water facilities

\section{WASTE WATER DISPOSAL TO GROUND AND SOIL COLUMN}

\section{Groundwater Quality Standards}

These standards establish concentration-based and other limits that must be met to preserve the quality of groundwaters of the state The parameters and himits for protectıng groundwater are referred to as the ground water qualıty criteria (GWQC) Discharges of waste water to the ground must be managed in a manner that will ensure the GWQC are satisfied and groundwater quality is not degraded Treatment technologies must be selected and implemented to ensure the GWQC are met

Evaluation Ecology typically implements the groundwater quality standards through permits or approvals for waste water discharges The groundwater quality standards would apply to the WFD system in those instances where a project or activity is required to have a permit or approval for discharging waste water to the ground

\section{State Waste Discharge Permit}

An SWDP is required for any industrial, commercial or municipal operations that may discharge waste materials in a manner that would allow pollutants to potentially enter groundwaters of the state An SWDP is not required for discharges of pollutants into navigable or surface waters already covered by a National Pollutant Discharge Elımınation System (NPDES) permit Facilities that dispose of solid materials in landfills typically are not required to obtain an SWDP if a separate disposal permit has been issued 
Before construction or modification, waste water facilities requirıng an SWDP permit must submit an application to Ecology, and must provide engineering reports, plans, and specifications for the project Effluent control systems are expected to include a combination of best management practices (BMPs) to minimize effluent and pollutant generation, and use of all known, avallable and reasonable treatment (AKART) for effluent streams prior to discharge Ecology must approve the SWDP application and accompanyıng materials before construction begins Operation and maintenance manuals must be submitted before construction is completed A monitoring system and plan is also required for these facilities, monitoring may include effluent testing vadose zone measurements, and/or groundwater sampling and analysis

To date, Ecology has issued three "categorical" SWDPs that may affect projects and activities associated with the WFD system These permits are as follows

1 SWDP No ST 4508, Hydrotest, Maintenance, and Construction Locations on the Hanford Site The types of activities covered by this permit include hydrotestıng discharges (including hydrotesting of a system or component and development testıng) mantenance discharges (Including drainage and flushing activities), and construction discharges (including concrete curing and pressure washing actıvities)

2 SWDP No ST 4509, Coolıng Water and Condensate Discharge Locations on the Hanford Site The types of activities covered by this permit include cooling water discharges (including from air compressors, diesel engines, arr conditioning, ventilation, evaporatıve coolıng, and ice machınes), condensate discharges (including from steam lines steam heatıng systems air compressors, air conditionıng, ventilation and ice machines), and other miscellaneous discharges (including from pump leaks valve wastewater water tank overflows, and quench tanks)

3 SWDP No ST 4510, Industrial Stormwater Discharges to Engineered Land Disposal Structures on the Hanford Site The types of activities covered by this permit include industrial stormwater discharges to ground that are collected in engineered structures (e $\mathrm{g}$, lined trenches, basins, retention structures, secondary containment structures, tanks, sumps roofs, parking lots other impervious surfaces) and then discharged to engineered disposal structures (e g injection wells, dry wells, catch basins, infiltration basins, infiltration trenches)

Each of these categorical SWDPs includes conditions on the rate and quantities of discharges sources of water, BMPs that must be developed and implemented, and record keeping and reportıng

Evaluatıon Depending on the work scope associated with a particular project or activity, any of the above categorical SWDPs are potentially applicable to the WFD system New waste transfer lines will probably be pressure tested (hydrotested) for integrity, pressure washing of new components prior to installation can be expected cooling water and condensates may be generated by WFD system operations and stormwater may need to be collected and managed 
for new buldings or structures (e $\mathrm{g}$, instrumentation facilities, pump houses) Project/actıvity representatives should coordinate with the facility ECO during initıal planning stages to determine whether their work scope may be subject to the categorical SWDPs and if so, to evaluate potential compliance requirements and permit conditions that must be satisfied in the facility design and operation

\section{Underground Injection Control Permit/Registration}

Authorization by Ecology of fluids injected through wells has been restricted to wells operational before February 29, 1984 New discharges of uncontaminated storm water and groundwater return flow, unaltered except for temperature from a groundwater heat pump used for heating or cooling, are the only discharges that are not prohibited These discharges must be registered with Ecology before construction begins and are subject to various conditions for underground injection

Evaluation None of the current or known future projects and activities associated with the WFD system involve construction or operation of an underground injection well The underground injection control standards are not expected to apply to the WFD system

\section{CONSTRUCTION AND SIGNIFICANT ACTIONS IN OR NEAR SURFACE WATER}

\section{Floodplain/Wetland Assessment}

DOE requires completion of a Floodplain/Wetland Assessment for all proposed activities in designated floodplains or in identified wetlands A proposed action shall be designed to minimize potential harm to or within a floodplain or wetland The assessment should be performed in conjunction with the NEPA evaluation process

\section{U S Army Corps of Engineers (USACE) Permit}

Dredging in and discharging dredge and fill material to, waters of the United States requires a permit from the US Army Corps of Engineers (USACE) before initiating the activity This often includes work in wetlands and along shorelınes where fill riprap, or similar materials are being placed (e g , permanent and temporary dikes effluent outfalls, pıpeline bedding)

\section{Natıonwide Permits}

The USACE issues general Nationwide Permits for certain activities that occur relatively often in waterways but that typically have minimal impacts The Nationwide Permits are intended to minimize delays, require little, if any, documentation and in many cases are self-implementing ( $1 \mathrm{e}$, no approval is required prior to begin work as long as notice is filed and permit conditions are met) Nationwide Permits are not applicable for projects within a Wild and Scenıc River study area 
HNF-2401

Revision 1

\section{WIId and Scenic Rivers, Section 10 Permit}

As noted above, USACE permits are required for construction in or adjacent to navigable waters and certain activities are covered by Nationwide Permits However, any work in an area designated as a "study river" for possible inclusion in the Wild and Scenic River System, such as the Hanford Reach, must obtain an individual Section 10 permit from the USACE prior to beginning work Projects which could adversely affect a the river study effort, or decision making about the final status of a wild or scenic river designation, are closely scrutinized controlled and/or prohibited

\section{Hanford Reach Study Act Notıfication}

Proposed construction within one-quarter mile of the Columbia River shoreline inside the Hanford Reach Area is subject to consultation and coordination with the National Park Service

\section{Hydraulıc Projects Permit}

Any construction or other work that will change the natural flow of a river, including the addition of treated effluent waste water that will increase the natural flow, is required to obtain a hydraulic project approval from the Washington State Department of Fisheries

\section{Shoreline Development Permit}

A state permit for developing the shorelıne is required before construction for shorelines that are not federally owned ( $1 \mathrm{e}$ the shoreline is under lease, easement, license, or other similar federal property rights, short of fee ownershıp) Shoreline development programs are implemented by local agencies (e $g$, Benton County) under authority delegated by Ecology

\section{Aquatic Lands Lease}

Aquatic land activities that interfere with the general public's use of state owned tidelands, shorelands, and beds of navigable waters require authorization before construction from the Washington State Department of Natural Resources by way of agreement, lease, permit, or other instrument(s)

Evaluatıon None of the current or known future projects and activities associated with the WFD system involve construction or operation in, adjacent to, or near surface waters Environmental standards affecting construction or significant actions in or near surface waters are not expected to apply to the WFD system 
HNF-2401

Revision 1

\section{WASTE WATER DISPOSAL TO SURFACE WATERS}

\section{Natıonal Pollutant Discharge Elımınatıon System (NPDES) Permit, Categorical Effluent Standards and Gudelines}

Discharge of pollutants to waters of the United States is required to have an NPDES permit before operation, and all surface water discharges must be registered The regulations prescribe effluent limitation guidelınes for existing sources, standards of performance for new sources, and pretreatment standards for new and existing liquid effluent sources Authonty for implementing the NPDES permit program is usually delegated to the state, and Ecology has NPDES delegation for nearly all of the program However, EPA stıll retains NPDES authority in Washington for discharges from federal installations Thus, the regulatory agency responsible for issuance of NPDES permits to the Hanford Site is EPA, although Ecology certification is required for each permit (see discussion, below)

The regulations require reduction of pollutants prior to discharge, and in general mandate the use of BMPs to minımize pollutants and effluents along with best avallable treatment technology for treating effluent discharges Montoring and reporting for discharges are required A number of regulations have been adopted that list constituent limits and best avallable treatment technology methods for discharges in specific industrial categories If a proposed discharge does not fall within an existing category, EPA adapts relevant standards from similar categories or, if necessary, develops specific standards for the discharge for inclusion in the NPDES permit

\section{Ecology Certification of an EPA NPDES Permit}

EPA may not issue an NPDES permit until a certification is granted or waved by Ecology Ecology must certıfy that all conditions necessary to ensure compliance with applicable federal and state water quality standards are met

\section{Stormwater Discharge Permits}

The Hanford Site is covered by one stormwater permit issued as a general permit under the NPDES program General Permit WA-R-00-000F covers stormwater runoff discharging to the Columbia River from industrial and construction areas of the Hanford Site If there is a potential for stormwater to reach the river, a request for authorization under the EPA general permit must be submitted and a stormwater pollution prevention plan must be in place 
HNF-2401

Revision 1

\section{Short-Term Surface Water Quality Modıficatıon Approval}

A permit, directive, or order as appropriate must be obtained from Ecology before undertaking an activity that will temporarily reduce water quality below the criteria and classifications established for the affected water body A water quality modification is generally only allowed under necessary but unavoidable circumstances, and will include BMPs treatment standards, or other actions needed to minimize impacts as much as possible

Evaluation None of the current or known future projects and activities associated with the WFD system involve discharges to surface waters Permits and other environmental standards affecting surface water discharges are not expected to apply to the WFD system

\section{RADIOACTIVE MATERIALS AND WASTE MANAGEMENT}

\section{General Radiatıon Protectıon Standards and Publıc/Envıronmental Monitoring}

DOE orders provide standards and guidelines for limiting public and environmental exposures to radionuclides, and require a written EMP for each site, facility, or process that uses generates releases, or manages significant pollutants or hazardous materials The EMP must include the rationale and design criteria for the monitoring program as well as describe the extent and frequency of the monitoring The EMP also must contain quality assurance requirements program implementation procedures, directions for preparation and implementation of reports, and directions for identification and discussion of effluent monitoring and environmental surveillance An EMP is prepared for all DOE activities on the Hanford Site and is updated every 3 years to include new or modified facilities and projects

The effluent monitoring portion of the plan must verify compliance with applicable regulations and DOE Orders For major facilities on the Hanford Site this is documented in the form of specific FEMPs Two thresholds are used to determine if a FEMP is required for a facility (1) if the total projected dose to a member of the public from radionuclides exceeds 01 millirem from any one discharge point, or (2) if any one regulated material discharged from a facility exceeds 100 percent of a reportable quantity or a permitted quantity Preparation of a FEMP assesses effluent monitoring systems and evaluates whether these systems are adequate to ensure the public health and safety as specified in applicable federal, state, and local requirements The FEMP ensures longrange integrity of the effluent monitoring systems by requiring an update whenever a new process or operation introduces new hazardous materials or significant radioactive materials This document must be reviewed annually even if there are no operational changes and it must be updated, at a minimum, every 3 years 
Evaluation Radiation protection standards are expected to apply to the WFD system, and projects and activities will need to be consistent and demonstrate compliance with applicable effluent monitoring requirements A FEMP specific to tank farm facilities exists and describes the monitoring expectations for air and liquid effluents (Crummel et al 1999) The requirements of this FEMP are expected to be relevant to the WFD system, and project/activity representatives should coordinate with the facility ECO during initial planning stages to evaluate potential compliance requirements

\section{Reprocessing of Spent Nuclear Fuel}

HLW is a source designation for the first stage of waste separated from processing irradiated nuclear fuel and other similar materials HLW should not be confused with high-actıvity waste, handling/design requirements apply differently Facilities whose primary function is to manage HLW must be designed in accordance with special requirements in DOE orders HLW is also classified as transuranic (TRU) waste if the waste form exceeds the activity level of 100 nanocuries/gram from TRU elements, at the time of final stage processing, and before dilution for pumping Most TRU processes must also meet criticality safety controls but in most cases these are not part of the environmental compliance issues Facility permits will incorporate all applicable complance criteria

\section{Management of High-Level and Low-Level Radıactive Waste}

All radioactive waste must be managed/stored in a way that prevents uncontrolled release of contaminants to off-site areas Requirements for HLW and low-level waste (LLW) management, handling packaging, treatment transport, and storage are summarızed in DOE orders, along with design criteria for facility construction (new or modified) to handle radıoactıve wastes

DOE policy is that only DOE controlled facilities will be used to dispose of LLW DOE policy also requires that all HLW and LLW be safely stored treated and disposed of in accordance with all applicable requirements, particularly those of the EPA and the jurisdictional state Because HLW and LLW often contain constituents that are regulated by other federal programs (e g hazardous waste), treatment storage and disposal processes must meet applicable standards for clean arr, clean water, solıd and hazardous waste, and protection of the environment The requirements of these other environmental programs are addressed in corresponding sections of this narratıve

Evaluatıon Applicable DOE requirements for managing spent nuclear fuel, HLW and LLW are being addressed as necessary in the projects and activities Applicable environmental standards referenced in the DOE requirements will also be satısfied throughout design and implementation of the WFD system 
HNF-2401

Revision 1

\section{SOLID AND DANGEROUS WASTE}

\section{Solnd Waste Facility Permit}

Facilities that dispose of solid wastes including inert wastes and construction debris, must be approved for operation by the jurisdictional county health department Operation must comply with the approval conditions and applicable solid waste management standards, which address practices such as daily cover, run-on and run off controls, wind and erosion controls, and final closure Facilities that dispose of household wastes" are subject to municipal solid waste landfill requirements, which in addition to the basic solid waste management practices include controls for vectors and pests, leachate and methane gas management, and groundwater monitoring The Hanford Site disposes of some inert and construction debris on site but does not currently operate a municipal solid waste landfill, all "household waste" is sent off-site for disposal

Evaluation Current and known future projects and activities for the WFD system do not include constructing or operating facilities that would be subject to the permit and compliance requirements for solid waste management or disposal These standards are not expected to apply to the WFD system

\section{Waste Oıls}

Waste oil may be subject to special management standards if it is a used oil that could be designated as a dangerous waste If a waste oil would not be a dangerous waste, or if the oil is sent to a re-refiner then no requirements apply Uses of dangerous waste used o1l that constitute disposal ( $\mathrm{g}$, road oiling) are prohibited or subject to full dangerous waste standards Most of the other waste oll requirements only affect marketers or burners of the waste orl If a waste oll is regulated and if it is burned for energy recovery, the marketer must ensure that the oil meets certain specifications prior to burning and the burner must maintain records showing the oll met the specifications when it was burned Marketers and burners must also submit one time notifications about their used orl activities to Ecology If a waste oll cannot be blended or otherwise treated to meet the specifications, it must be burned in accordance with more stringent requirements for industrial furnaces or bollers An exception is made for small space heaters used to burn off-specification waste oils generated on-site

Evaluation None of the tank farm or other wastes that will be retrieved, transferred and delivered by the WFD system meet the definition of waste orls, and orl blending and burning for energy recovery are not conducted at the tank farms, so these standards are not expected to directly apply to the WFD system Waste otls may be generated durıng routıne maintenance of vehicles, construction equipment, hydraulic devices, and other machinery used to build and operate the WFD system Projects and activities will need to ensure that waste olls generated within their scope of work are collected and dispositioned in accordance with the Hanford sitewide used oil management program 


\section{Dangerous Waste Notice Of Intent}

A Notice of Intent is required for new or expanding facilities that perform treatment, storage and/or disposal (TSD) of dangerous wastes Expansion includes enlargement of land surface area, the addition of new dangerous waste processes, or an increase in overall design capacity The NOI contains prelıminary information concerning the proposed facility and/or expansion including a general process description, operating capacities waste type, a topographic map, and a statement of environmental conditions, which could include a SEPA environmental checklist or a SEPA adoption letter The Notice of Intent is filed with Ecology published, and submitted to the public for review Approval of the notice and supporting documentation must be received before new construction or expansion can begin

Evaluation At this time, current and known future projects and activities that support the WFD system are not expected to qualify as "proposed" facilities or as facllity "expansions" under the Notice of Intent requirements These standards are not considered to be applicable to the WFD system This applicability determination will be confirmed periodically as the WFD system definition is further refined

\section{Interım Status and Final Status Standards for Dangerous Waste Management Facilitıes}

Implementing regulations promulgated pursuant to the federal Resource Conservation and Recovery Act of 1976 (RCRA) require dangerous waste TSD facilities to comply with numerous design and operatıng requirements and to obtain a permit Facilities that were in existence on November 19,1980, were granted interım status with the submittal to EPA (and Ecology) of a Part A form, describing the dangerous waste TSD activities at the facility The Part A identifies the dangerous waste numbers and estımated annual quantities managed, general process information and design capacity, faclity diagrams, photographs geographic location, and facility owner and operator/co operator certification Interim status changes can be requested from Ecology via the Part A Once the revised Part A (and Notice of Intent if the change constitutes "expansion " see discussion above) is submitted, construction can proceed if Ecology concurs with the proposed change Otherwise, a final status permit must be issued by Ecology before the modifications and construction can begin

The process for obtaining a final status permit consists of submitting a Part A and a Part B permit application The Part B provides much more detalled descriptions of the processes used for managing dangerous waste The Part B is evaluated by Ecology for completeness and technical adequacy, plausibility, general detall of plans and procedures, and protection of human health and the environment Resolution on inadequacies can be reached formally by Ecology issuing a notice of deficiency or informally by the use of a workshop or similar process When satısfied with the Part B Ecology prepares a draft final status permit which is published for public and interagency review On completion of the public review period, significant public comments are factored into the final status permit issued by Ecology A final status permit is granted after final adminıstrative disposition of the permit application and supporting documentation Under limited 
HNF-2401

Revision 1

circumstances Ecology may allow construction to commence before final status approval

For the Hanford Site, one dangerous waste final status permit has been issued for the Hanford Facility The Hanford Facility Dangerous Waste Permit (Ecology and DOE 1999) consists of numerous general conditions that are applicable sitewide (e $g$, emergency procedures, personnel training), plus unit-specific chapters that describe physical and operating conditions for particular dangerous waste units at the Hanford Site (e g , 242-A Evaporator Liquid Effluent Retention Facility/Effluent Treatment Facility) Until a particular unit is incorporated into a unit specific chapter of the Hanford Facility Dangerous Waste Permit it contınues to operate under intermm status A schedule has been developed for requesting and processing final status permits for all active Hanford TSD units, and on completion of the unit-specific Part B process each TSD unit will be added to the Hanford Facility Dangerous Waste Permit

Evaluatıon Currently, the DST system is operatıng under interım status, with a calendar year 2000/2001 timeframe for final status permitting Until then, changes to the DST system are being treated as interım status modifications, and the DST system is expected to be fully compliant with applicable interim status standards, unless some other compliance schedule has been negotiated with Ecology The SST system is currently operating under interim status In accordance with agreements established in the Hanford Federal Facllity Agreement and Consent Order (Ecology et al 1996) also referred to as the Tri-Party Agreement, the SST system is expected to be closed and will not be required to obtain a final status permit Modified and replaced equipment is to be in compliance with applicable interim status standards

Most, if not all of the WFD system must currently comply with interim status standards Most, if not all, of the WFD system is expected to be included withın the DST system final status permit and will be required to comply with the final status standards Some portions of the WFD system may be withın the SST system, and current understanding of the Tri Party Agreement is that the SST elements of the WFD system will not have to comply with the final status standards In addition these SST elements may not have to comply with the interm status standards, unless they are replaced or modified Projects and activities that support the WFD system will be expected to satısfy those dangerous waste requirements that apply to their scope of work Project/activity representatives should coordinate with the facility ECO during initial planning stages to evaluate whether interm or final status standards apply, and to determine the applicable compliance requirements

\section{Permits for Trial Burns and Other Demonstrations}

Certain temporary activities can be conducted with dangerous waste in order to test TSD processes in support of final facility design and/or operation Short-term permits can be issued for trial burns, land treatment demonstrations and research, development, and demonstration of new systems These permits are processed relatively quickly, limit the quantities of dangerous waste that can be managed, have limited durations, and generally are less burdensome and have fewer explicit requirements 
HNF-2401

Revision 1

Evaluation Current and known future projects and activities for the WFD system do not Include constructing or operatıng facilities to conduct trial burns, land treatment demonstrations, or research and development work These standards are not expected to apply to the WFD system

\section{Miscellaneous Requirements for Dangerous Waste Management}

Other requirements within the regulations necessitate submittal of various notifications, certifications and/or approval requests to Ecology Significant obligations include the following

- Notıfication and reporting for treatability studies involving dangerous waste samples

- Notification that dangerous waste may be land disposed in accordance with the treatment and other requirevitents of the land disposal restrictions

- Certification by a professional engineer that all surface impoundment, waste pile, and landfill units have been built in accordance with a construction quality assurance program

- Notification of intent to begin closing a TSD unit, or that portions of a TSD unit will undergo partial closure

- Notice that unplanned releases of dangerous waste constituents from a TSD unt to the environment have been detected, with submittal of corrective action response plans

Evaluation The relevance and applicability of the miscellaneous dangerous waste requirements will depend on project and activity-specific circumstances In general, the following analyses of the requirements are likely for most WFD system work

- Some WFD system definition and design decisions may depend on performance of laboratory tests for physical properties and chemical/radiological makeup of tank farm waste samples It is not known whether any of these tests will meet the "treatability study" definition in the regulations If so the performing laboratory will need to notıfy Ecology and maintain test and waste sample handling records

- Required land disposal restriction notifications will need to be made at some future time when waste feed delivery to BNFL Inc begins The type and level of detall of information to be included in these notices have not been determined yet

- It is possible that unanticipated contamination of the environment may be encountered during work in the tank farms, although this is not expected for the known work scope of the current projects that support the WFD system If the contamination involves releases of dangerous waste constituents, the unplanned release notifications and corrective action requirements could apply 
- Land-based disposal units are not expected to be within the scope of work for establishing the WFD system Closure or partial closure of the DST and SST systems is not antıcipated during Privatization Phase 1, so these requirements would not be expected to be within the current WFD system scope

\section{HAZARDOUS SUBSTANCES AND PETROLEUM PRODUCTS}

\section{Toxic Substances}

EPA has adopted regulations pursuant to the federal Toxic Substances Control Act (TSCA) which require persons who produce chemical products (e g , paints, solvents, process chemicals) to provide a pre-manufacture notıfication to EPA Some research and development activities are exempted from TSCA pre-manufacture notices for "de minimus" quantities EPA reviews the notice and supporting information and may impose restrictions on the distribution and use of a chemical product A chemical producer is required to prepare and maintain a material safety data sheet for distribution with their products

Evaluation Current and known future projects and activities for the WFD system do not include manufacturing or producing chemical products that would be subject to notification or preparation of a material safety data sheet These standards are not considered to be applicable to the WFD system

\section{Polychlorinated Biphenyls (PCBs)}

Polychlorinated biphenyls (PCBs) use, handling and disposal are subject to requirements established by EPA under the authority of TSCA In general, a unit (e g, transformer, capacitor) or waste may be subject to regulation if the initial concentration of PCBs in the unit or waste was greater than 50 parts per million (ppm) (Wastes containing PCBs with inttial concentrations between 2 and $50 \mathrm{ppm}$ may be regulated as dangerous waste, see dangerous waste requirements discussed above) TSCA PCB Disposal Amendments effective on August 28, 1998, incorporated new provisions for the management of certain PCBs Major changes include the addition of several new PCB waste categories and associated disposal options Regulated categories include PCB liquids PCB Items, PCB Remediation Waste, PCB Bulk Product Waste, PCB Household Waste, PCB Research and Development Waste PCB/Radıoactıve Waste, and Porous Surfaces

The PCB Disposal Amendments are applicable to all TSCA-regulated PCBs at Hanford including any PCBs that may have been or will be sent to the DST system or SST system Classification of TSCA regulated PCBs can be accomplished if adequate knowledge exists regarding the PCB source to determine its category Once the PCB source is known, the appropriate management approach can be determined At Hanford, many PCBs have been found for which best efforts have resulted in an inability to identify the sources 
Evaluation To date, there have been limited circumstances under which PCBs have been found in or may have been introduced to the DST system so far, none of these circumstances has led to the conclusion that TSCA-regulated PCBs have been generated in or discharged to the DST system In addition current tank farm waste acceptance procedures prohibit the acceptance of PCB-containing wastes that would be TSCA-regulated The same procedures also require an extensive information collection and demonstration process to show that a proposed waste transfer to the tank farms does not contain TSCA-regulated PCBs Consequently, the current opinion is that the DST system is not now and is not expected to be subject to the TSCA regulations for PCBs Current and known future projects and activities for the WFD system are not expected to change this status by independently generating or managing TSCA-regulated PCBs Therefore, these standards are not considered to be apphcable to the WFD system However, some caution is warranted regarding this position, because data and information regarding possible PCBs in the tank farms is still emerging Untıl a more substantial body of knowledge is established project/activity representatives should periodically coordinate with the facility ECO to reconfirm the status of the PCB regulations as they apply to the WFD system

\section{Ozone Depletıng Substances, Spent Fluorocarbons, Volatıle Organic Compounds}

EPA has established reportıng trainıng, and operatıons requirements for any person who produces transforms, destroys imports or exports a controlled (ozone depleting) substance (e g chlorofluorocarbons) These compounds are to be recovered and recycled to the maximum extent practical, and their eventual use is to be phased out In addition, Ecology regulates spent chlorofluorocarbon and hydrochlorofluorocarbon refrigerants as dangerous waste, but imposes less stringent standards if the spent material is recycled in accordance with certain conditions Finally, Ecology regulations restrict releases of volatıle organic compounds to the atmosphere from various operations, and require controls and monitoring to minımize potential releases

Evaluation Ancillary systems (e g chillers air conditioners) that support tank farm operations may be using ozone depleting substances, and projects or activities that affect these systems may be required to satisfy the applicable regulations Generally, refrigeration and cooling services are provided by licensed contractors who capture and recycle the regulated substances The tank farms do not meet any of the regulated volatile organic emission categories established in the regulations so the Ecology standards do not apply Project/activity representatives should coordinate with the facility ECO during initial planning stages to determine potential compliance requirements

\section{Asbestos}

Asbestos is a controlled carcinogen and all work involving asbestos containing materials must be done by trained and certified personnel Any proposed reconstruction, repair, or demolition involving asbestos must be reviewed for possible pre-project notification to the BCAA All notifications are handled by a central office for the entire Hanford Site 
Evaluatıon Asbestos containıng materials are not managed in the tank farms, and projects and activities to upgrade the WFD system are not expected to use or install equipment or materials that contain asbestos It is possible that some equipment or items (e $g$, gaskets pipe insulation) removed during upgrades to the WFD system could be asbestos-containing materials, and these materials may be subject to the asbestos removal, packaging and disposal regulations Project/activity representatives should coordinate with the facility ECO during initial planning stages to determine potential compliance requirements

\section{Bulk Fertılızers, Insectıcides, Pestıcıdes, Rodentıcıdes, Fungicides and Herbıcıdes}

The Washington State Department of Agricultural has established regulations for the storage and management of bulk volumes (e g, 55 gallons) of fertilizers Secondary containment and spill response procedures are required

Miscellaneous poisons are controlled by the Federal Insecticlde Fungicide and Rodenticide Act (FIFRA) Users must comply with requirements for training, usage, handling, storage, application, disposal and record keeping of compounds regulated pursuant to FIFRA The Washington State Department of Agriculture is authorized to implement these regulations

Evaluatıon The tank farms are not used to prepare, apply, or dispose of fertlizers, pesticides, or related materials Some herbicide application occurs to control vegetation growth in and around the tank farms, but this work is performed by the facility landlord and maintenance services for the overall Hanford Site and is not expected to be within the WFD system projects and activities work scope These standards are not considered to be applicable to the WFD system

\section{Underground Storage Tank (UST) Permit}

Any active Underground Storage Tank (UST) that stores or manages petroleum products or other unused (raw material) hazardous substances must have a UST permit must be operated in accordance with applicable standards, and must periodically certify to Ecology that it complies with the standards The UST includes any ancillary piping or equipment needed to fully operate the tank, and a tank system is considered to be a UST if 10 percent or more of the system (including piping and ancillary equipment) is located below ground surface UST requirements include tank design standards inventory control practices corrosion prevention and control, integrity testing and inspections, leak detection and response procedures, and reporting The Hanford Site DST system and SST system are not subject to the UST standards Tanks that would be subject to the UST standards include underground tanks storing fuel for diesel generators, or underground tanks used to store regulated process chemicals 
Evaluation The tank farms do not store or manage petroleum products or other regulated hazardous substances, so the DST system itself is not subject to the UST standards A number of underground diesel fuel tanks are located in the 200 East and West Areas but these are not located within the tank farms Projects or activities supporting the WFD system may install tanks to store chemical reagents ( $\mathrm{e} g$, sodium hydroxıde) that will be used to adjust waste properties or in maintainıng transfer equipment ( $\mathrm{e}$, for line flushing) Current and known future work scope does not include locating such units underground typically they would be skid mounted or otherwise placed above ground These standards are not considered to be applicable to the WFD system Project/actıvity representatives should coordinate with the facility ECO during initial planning stages to confirm that UST requirements will not apply to the expected work scope

\section{Oıl Spill Preventıon Planning and Response}

Facilities that receive, store or dispense bulk quantities of oils and petroleum products in locations where releases could discharge to state or U S surface waters are required to prepare and implement spill prevention plans Washington state regulations apply to facilities that load or offload relatively large volumes (e g , 3,000 gallons) of petroleum products from vessels, to date, these requirements have not been applicable to Hanford Site operations The federal spill prevention control and countermeasures program regulates smaller volumes of petroleum products and oils (including plant and animal derived orls), and is applicable to any storage activities, not just loading/offloading facilities If stored volumes exceed threshold quantities and the storage units (which include containers as well as tanks) are located near the Columbia River or other surface water bodies, then a spill prevention control and countermeasures plan must be prepared and submitted to EPA The spill prevention control and countermeasures plan must be implemented in the event of a spill or release

Evaluation The tank farms do not, and are not expected to, include any facilities that store, load or offload bulk oıl or petroleum products near surface water bodies These standards are not considered to be applicable to the WFD system

\section{Pollution Prevention, Waste Minimization, and Community Right-To-Know Notıfication and Reporting}

Various regulations and orders require implementation of pollution prevention and waste minımization practices In general, these programs include the following features

- Track material use, waste generation rates and recycling rates

- Prioritize pollutants and waste streams for reduction

- Conduct process waste assessments or pollution prevention opportunity assessments on priority waste streams and identify cost-effective pollution prevention opportunities 
HNF-2401

Revision 1

- Implement cost-effective pollution prevention opportunities

- Incorporate pollution prevention into the design of new projects or activities

- Report on material usage, waste generation, recycling, and progress made due to implementing pollution prevention practices

All Hanford facilities are covered by the Hanford Site Waste Minimization and Pollution Prevention Plan New facilities must develop a Pollution Prevention/Waste Mimimization strategy and incorporate relevant guidelines into any operations prior to startup Plan and report information are submitted to Ecology and other agencies as required

Regulations adopted pursuant to the federal Emergency Planning and Community Rightto-Know Act (EPCRA) require that information about the types, locations, and hazards of specified substances be provided to state and local emergency response authorities EPCRA also requires that annual reports be submitted to EPA to document releases to the environment of chemicals used in excess of established threshold quantities State and local notices and annual reporting are coordinated through a single office for the entire Hanford Site

Evaluation All projects and operations at the tank farms must comply with standards for waste minimization and for EPCRA notification and reporting These requirements are implemented through various tank farm and site wide procedures Projects and activities that support the WFD system will be expected to satisfy the applicable planning and reportıng requirements for their scope of work Project/activity representatıves should coordinate with the facility ECO during initial planning stages to determine potential compliance requirements and to ensure that applicable notification and reporting instructions are included in field work orders and procedures, as necessary

\section{Notıfication and Remediation of Environmental Releases}

Unpermitted releases to the environment of petroleum products and hazardous substances are subject to requirements for notification and remediation under the federal Comprehensive Environmental Response Compensation and Liabllity Act (CERCLA) and the Washington State Model Toxics Control Act (MTCA) Notıfication is required if a release exceeds the reportable quantity (or other regulatory threshold) for the released compound Releases, whether reportable or not, may also be subject to remediation requirements if EPA or Ecology determine the release poses a threat to human health or the environment Releases from regulated USTs or from dangerous waste facilities are usually addressed under their respective programs first However, CERCLA and MTCA requirements may apply if the responsible party farls to respond, or for calculating acceptable cleanup levels for the regulated constituents

The Hanford Site has been included on the CERCLA National Prionities List for a number of past practices operable units at which environmental releases occurred The 
HNF-2401

Revision 1

Tr1 Party Agreement documents how CERCLA operable units are to be remediated, and most Hanford CERCLA actions are the responsibility of the Environmental Restoration Contractor (Bechtel Hanford, Inc ) While CERCLA remedial actions are generally exempt from administrative burdens (e g, permits), they must satisfy the substantıve provisions of applicable or relevant and appropriate requirements Activities associated with CERCLA operable units may be subject to restrictions intended to minımize further contamination or contaminant migration The DST system and SST system are not considered to be CERCLA operable units however portions of the DST/SST systems may be located within or adjacent to CERCLA operable units and could be affected by CERCLA decisions and activities

Evaluation The most likely sources of environmental releases that might be discovered in the tank farms will be subject to notıfication and corrective action standards established under the dangerous waste regulations However, it is possible that spills of petroleum products or chemical reagents could occur during construction or operations in a tank farm (e g, gas tank rupture, chemical addition leak) It is also possible that construction or other work needed to build or operate the WFD system could encounter contamination outside the tank farms, from known or unanticipated past practices (e g , transfer line construction through abandoned spill or disposal area) If unpermitted spills or releases occur (or are encountered), site-wide notification and reporting procedures would be followed and coordinated through a central office Site emergency response procedures would be implemented to contain and remove spilled materials Site cleanup and remediation contractors would be involved in addressing past practice releases and abandoned disposal sites that are not within or extend outside of, tank farm boundaries Although the likelihood of unanticipated events occurring is expected to be small, the CERCLA and MTCA requirements are potentially applicable to projects and activities that support the WFD system Project/activity representatives should coordinate with the facility ECO durıng initial planning stages to determıne potential compliance requirements and to ensure that applicable notffication reporting, and response instructions are included in field work orders and procedures as necessary 
HNF-2401

Revision 1

\section{APPENDIX B}

\section{ESTIMATED LEVELS OF EFFORT FOR ENVIRONMENTAL PERMITS AND APPROVALS FOR THE WASTE FEED DELIVERY SYSTEM}


HNF-2401

Revision 1

This page intentıonally left blank

B 2 
HNF-2401

Revision 1

\title{
APPENDIX B
}

\section{ESTIMATED LEVELS OF EFFORT FOR ENVIRONMENTAL PERMITS AND APPROVALS FOR THE WASTE FEED DELIVERY SYSTEM}

\begin{abstract}
A substantral body of experience has been gained in obtainıng environmental permits and approvals for facilities within the River Protection Project (RPP) In addition to providing a reliable source of scientific and technical expertise, this experience base can be used to help estımate the level of effort needed to satısfy applicable environmental standards Information about resources and, more importantly, durations and timeframes associated with different types of environmental actions will be needed when developing cost, schedule, and staffing plans for waste feed delivery (WFD) system projects and activities
\end{abstract}

Table B-1 lists significant environmental actions which, based on the evaluations presented in the rest of this document, have been found to be potentially applicable to the WFD system For each environmental action Table B-1 lists various tasks that may be necessary to obtain relevant permits or approvals, or to otherwise demonstrate compliance with applicable standards For each listed task, the table provides estımates for labor, other costs, and duration

- Labor represents the approximate number of direct labor hours that experienced, qualified RPP personnel would require, on average, to complete the task The labor estımates include all staff time and do not allocate effort to types of personnel (e $g$, scientıst, clerical, manager)

- Other costs are indicated if sigmificant "purchased" expenses can be anticipated for the particular task Direct RPP labor hours are not included in the other cost estımates Other costs may include items such as facilities, equipment, materials, printing, travel, laboratory subcontractors, and hired services

- Duration describes the approximate amount of time needed from start to finısh to complete the task Duration is generally independent of the labor effort and in most cases is controlled by external factors such as agency review times, mandatory periods for public notice and/or hearıngs, or preset approval cycles (e g, semi-annual permit renewal) Durations for multiple tasks are not necessarily additıve, some tasks are sequential but others may be able to proceed in parallel

The information in Table B-1 is intended for managers and planners to use for initial planning purposes and to anticipate significant work, schedule, and resource constraints that may affect their projects and activities Not all of the identified environmental actions or tasks will be applicable to each particular project or activity, and the estımates only represent "typical" levels of effort The estimates should be treated as approximations that must be further refined for detalled project and actıvity specific planning 
Table B-1 Estımated Levels Of Effort For Environmental Actıons and Tasks (3 Sheets)

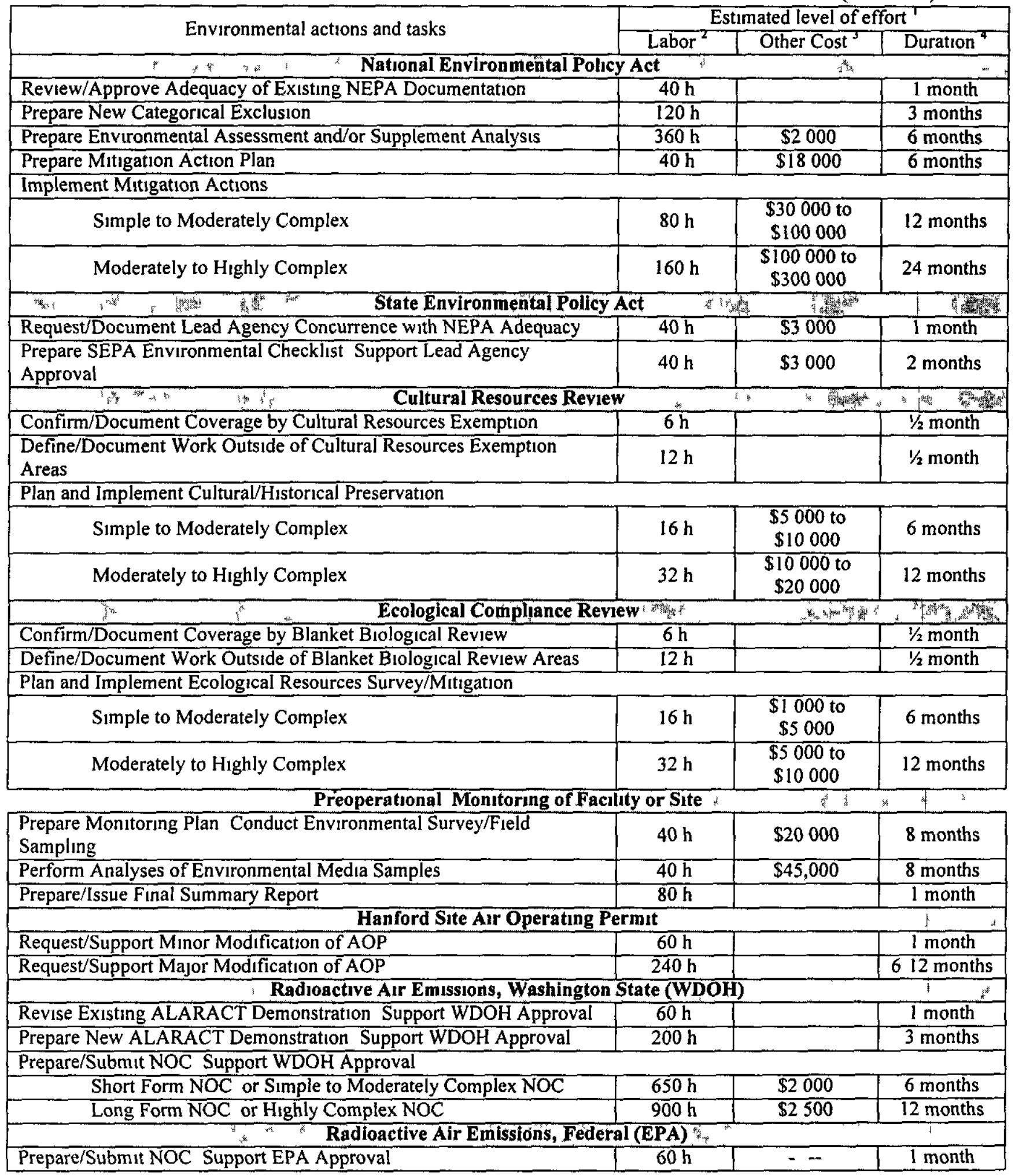


HNF-2401

Revision 1

Table B-1 Estımated Levels Of Effort For Environmental Actions and Tasks (3 Sheets)

\begin{tabular}{|c|c|c|c|}
\hline \multirow{2}{*}{ Environmental actions and tasks } & \multicolumn{3}{|c|}{ Estimated level of effort ${ }^{T}$} \\
\hline & Labor $^{2}$ & Other Cost $^{3}$ & Duration $^{4}$ \\
\hline \multicolumn{4}{|c|}{ Non-Radioactive Air Emissions, Washington Stăte (Ecology) Whe } \\
\hline $\begin{array}{l}\text { Prepare PSD/NSR Self Implementing (No Ecology Concurrence } \\
\text { Needed) }\end{array}$ & $60 \mathrm{~h}$ & & 1 month \\
\hline Prepare PSD/NSR Request/Document Ecology Concurrence & $120 \mathrm{~h}$ & & 2 months \\
\hline \multicolumn{4}{|l|}{ Prepare/Submit NOC Support Ecology Approval } \\
\hline Simple to Moderately Complex NOC & $650 \mathrm{~h}$ & $\$ 2,000$ & 8 months \\
\hline Highly Complex NOC & $1000 \mathrm{~h}$ & $\$ 2,500$ & 12 months \\
\hline BACT Assesment & $100300 \mathrm{~h}$ & & 2 months \\
\hline \multicolumn{4}{|c|}{ 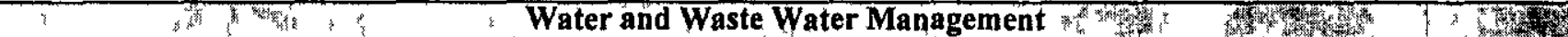 } \\
\hline Review/Approve Drinking Water Supply System Modifications & $60 \mathrm{~h}$ & & 3 months \\
\hline Review/Include SWDP Conditions in Waste Water Disposal Procedures & $60 \mathrm{~h}$ & & 3 months \\
\hline \multicolumn{4}{|c|}{ 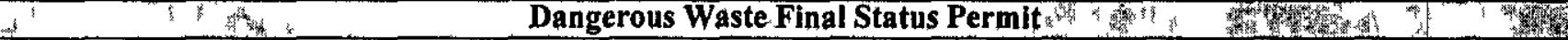 } \\
\hline Request/Support Class 1 Permit Modification & $120 \mathrm{~h}$ & & 2 months \\
\hline Request/Support Class 2 Permit Modification & $300 \mathrm{~h}$ & $\$ 1000$ & 10 months \\
\hline Request/Support Class 3 Permit Modification & $600 \mathrm{~h}$ & $\$ 2000$ & 12 months \\
\hline Project-/Activity-Specific Environme & al Planning & & $e^{4} x+2$ \\
\hline Prepare Environmental Strategy and Plannıng Summary & $60 \mathrm{~h}$ & & 1 month \\
\hline Prepare and Issue EPAP (or equivalent environmental plan) & $200 \mathrm{~h}$ & & 3 months \\
\hline \multicolumn{4}{|l|}{ Perform Annual Update of EPAP (or equivalent) } \\
\hline Simple to Moderately Complex & $60 \mathrm{~h}$ & & 1 month \\
\hline Moderately to Highly Complex & $160 \mathrm{~h}$ & & 2 months \\
\hline Environmentar Compliance and Readi & ss Suppärt si & & 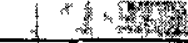 \\
\hline Provide Guidance/Issue Resolution During Conceptual Design & $5 \mathrm{~h} / \mathrm{wk}$ & & PoP \\
\hline Provide Guidance/Issue Resolution Durıng Definitıve Desıgn & $5 \mathrm{~h} / \mathrm{wk}$ & & PoP \\
\hline Review Work Packages/ECNs During Construction & $5 \mathrm{~h} / \mathrm{wk}$ & & $\overline{\mathrm{PoP}}$ \\
\hline Support Onsite Inspections During Construction & $3 \mathrm{~h} / \mathrm{wk}$ & & PoP \\
\hline Support Readıness Assessment/Operational Readıness Review & $3 \mathrm{~h} / \mathrm{wk}$ & & PoP \\
\hline Provide Interpretation/Issue Resolution During Operational Sta & $3 \mathrm{~h} / \mathrm{wk}$ & & PoP \\
\hline
\end{tabular}

$\begin{array}{ll}\text { ALARACT } & \text { As low as reasonably achievable control technology } \\ \text { AOP } & \text { Air operating permit } \\ \text { BACT } & \text { Best avalable control technology } \\ \text { Ecology } & \text { Washıngton State Department of Ecology } \\ \text { ECN } & \text { Engineering Change Notice } \\ \text { EPA } & \text { U S Environmental Protection Agency } \\ \text { EPAP } & \text { Environmental permits and approvals plan } \\ \text { NEPA } & \text { Nattonal Environmental Policy Act of } 1969 \\ \text { NOC } & \text { Notıce of construction } \\ \text { NSR } & \text { New source review } \\ \text { PoP } & \text { Period of Performance } \\ \text { PSD } & \text { Prevention of significant deterioration } \\ \text { RPP } & \text { River Protection Project } \\ \text { SEPA } & \text { Washington State Environmental Policy Act } \\ \text { SWDP } & \text { State waste discharge permit } \\ \text { WDOH } & \text { Washington State Department of Health }\end{array}$

'Estımates in this table are provided for initial planning purposes only The estımates should be treated as approximatıons that must be further refined for detalled project and actıvity specific planning 


\section{Table B-1 Estımated Levels Of Effort For Environmental Actıons and Tasks (3 Sheets)}

\footnotetext{
${ }^{2}$ All labor estimates are provided in hours (h) unless indicated otherwise Labor estimates account for all staff tıme including professıonal and adminıstratıve

${ }^{3}$ Other costs indicate estımated expenses for significant support that may need to be purchased to accomplish the particular task (e $\mathrm{g}$ facilities equipment materıals printıng travel laboratory subcontractors) Direct RPP labor hours are not included in the other costs estimates direct labor costs should be determined using approved planning and estımatıng tools (e $\mathrm{g}$ Prımavera@ Microsoft Project(B) For tasks where the principal cost is direct RPP labor the symbol appears to signify that significant other costs are not anticipated Other cost estımates are in current dollars without escalation

${ }^{4}$ Duration is provided for start to finish performance periods In most cases duration is independent of labor effort and controlled prımarıly by external factors (e $\mathrm{g}$ agency review tımes mandatory public comment perıods Not all tasks are sequential ( $1 \mathrm{e}$ some are able to proceed in parallel with others) and some tasks are repetitive so durations should not be assumed to be additive Schedulers will need to account for overlapping performance periods that start and end at different tımes when planning environmental tasks over a project $s$ or actıvity $s$ life cycle

${ }^{\text {s} E n v i r o n m e n t a l ~ c o m p l i a n c e ~ r e a d i n e s s ~ t a s k s ~ a r e ~ e s t ı m a t e d ~ a s ~ a ~ l e v e l ~ o f ~ e f f o r t ~ t o ~ b e ~ s u s t a i n e d ~ f o r ~ t h e ~ t a s k ~}$ duration Labor and cost estımates are provided on a weekly basis (e $g$ hours per week [h/wk]) and can be multiplied by the number of weeks the task is scheduled to occur to determine total resource needs Task duration depends on the particular project or activity demands and will be defined on a case by case basis by the schedulers so PoP (period of performance) is the indicated duration
} 


\section{DISTRIBUTION}

\section{Onsite}

US Department of Energy

Richland Operations Office

Reading Room

$\mathrm{H} 2-53$

42

CH2M HILL Hanford Group, Inc

Allen, D I

$\mathrm{R} 2-50$

Bryan, C B (5)

R2-58

Carrell, D J (5)

R1-51

Dexter, M L

R1-51

Dixon, W T (5)

R1-51

Dodd, R A

R3-72

Erlandson, B G (5)

R1-51

Haass, C C

H6-64

Mayer, E E

R2-50

Miller, P C (5)

R1-51

O'Toole, S M

R2-89

Payne, M A

$\mathrm{R} 2-58$

Popielarczyk, R S

$\mathrm{R} 2-58$

Powell, R W (5)

R3-75

Rice, C J

R2-53

Thompson, $\mathrm{W} T$

R3-73

Tollefson, $\mathrm{K}$ S

RI-51

White, K A

S5-13

DE\&S Hanford, Inc

Hammond D M

R1-44

1

Informatics, Inc

Root, R W, Jr

R2-53

2

Lockheed Martın Services, Inc

Central Files

B1-07

Document Processing Center

A3-94 


\section{DISTRIBUTION (cont)}

\section{Onsite}

MACTEC

DeWeese, G C

R3-73

Potter, R D (2)

R3-73

Numatec Hanford Corporation

Choho, A F (5)

R3-73

1

Pacific Northwest National Laboratories

Hanford Technical Library

P8-55 